DISSERTAÇÃO APRESENTADA AO PROGRAMA DE PÓS-GRADUAÇÃO EM ARTES VISUAIS ÁREA DE CONCENTRAÇÃO: POÉTICAS VISUAIS, LINHA DE PESQUISA: PROCESSOS DE CRIAÇÃO EM ARTES VISUAIS DA ESCOLA DE COMUNICAÇÕEs E ARTES DA UNIVERSIDAdE DE SÃo PAULO, COMO EXIGÊNCIA PARCIAL PARA OBTENÇÃO DO TítUlO DE MESTRE EM ARTES, SOB A ORIENTAÇÃO DA PROFA. DRA. BRANCA COUTINHO DE OLIVEIRA 



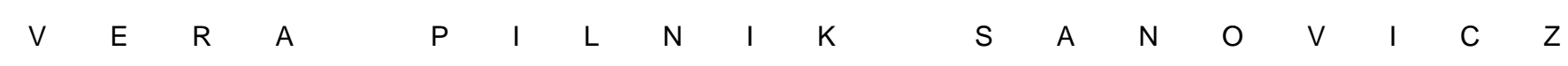

$$
\begin{array}{llllllllllllllllll}
a & l & e & m & d & a & c & 0 & r & t & i & n & a & p & r & e & t & a
\end{array}
$$

DISSERTAÇÃO APRESENTADA AO PROGRAMA DE PÓS-GRADUAÇÃO EM ARTES VISUAIS ÁREA DE CONCENTRAÇÃO: POÉTICAS VISUAIS, LINHA DE PESQUISA: PROCESSOS DE CRIAÇÃO EM ARTES VISUAIS DA ESCOLA DE COMUNICAÇÕES E ARTES DA UNIVERSIDAde dE SÃO PAULO, COMO EXIGÊNCIA PARCIAL PARA OBTENÇÃO DO TítULO DE MESTRE EM ARTES, SOB A ORIENTAÇÃO DA PROFA. DRA. BRANCA COUTINHO DE OLIVEIRA 



Em determinados momentos do dia ou da noite, acúmulos de cores e densidades luminosas, silêncios ensurdecedores e indefiníveis vazios, despertam a minha atenção: são episódios e acontecimentos de uma rotina. Uma rotina que inclui, nas andanças pela cidade, o porte de uma máquina fotográfica, coisa que poderia ser dita a respeito de qualquer um de seus usuários, não fosse esse dispositivo uma espécie de prolongamento do meu corpo e consciência. A captura de imagens por meio dessa "consciência protética", mediante diferentes gêneros de câmeras fotográficas (analógicas e digitais), e o tratamento das mesmas, ao longo de todo o processo de fabricação do trabalho (sobreposição e condensação de imagens) apresentam um conjunto de impressões visuais que se destinam a compor um experimento estético: não-vazios, não lugares, caminhos que se sobrepõem até já não mais poderem ser trilhados. A cidade, de repente, torna-se um lugar de ninguém, um lugar de passagem despido de qualquer materialidade: uma pura superfície expressiva. A cidade-imagem, fluída e flutuante, devém aquosa, inventada por meio de infiltrações de luz, para além da cortina preta... 

During certain moments of day or night, the accumulation of colors and bright densities, deafening silences and indistinct emptinesses, rouse my attention: They are scenes and events of a more or less usual routine. Routine that includes, when drifting through the city, the possession of a camera, something that could be said about ony of its inhabitants, noteworthy is the fact that there is a kind of prolongation that makes this camera part of my body and consciousness. Meanwhile, the capture of images through different cameras (analogical and digital) and the treatment of those images during the whole course of processing, like the superposition of one image to another, reveals a wide range of visual impressions that fulfill an esthetic experience: no-emptiness, no-places, paths that overlap until they can no longer be trailed. The city, suddenly, is a no one-man place, a passage free of any materialism: a pure expressive surface. The city-image, fluid and floating, becomes watery, invented by the infiltration of the light, beyond the black curtain... 

Branca, correr o risco de ter me acolhido é algo pelo qual serei eternamente grata.

não poderia deixar de agradecer...

A contribuição dos professores participantes da Banca do Exame de Qualificação: Prof. Dr. Leon Kossovitch e Prof. Dr. Evandro Carlos Jardim.

Ao meu sogro Prof. Dr. Abrahão Sanovicz, (in memoriam) e suas provocações que deram início a esta jornada.

À amiga, Profa. Dra. Mirthes Marins, e o abrigo fornecido na Faculdade Santa Marcelina.

À obra fotográfica de Geraldo de Barros, que por pura ignorância, só conheci em 2002 e que rompeu com a minha preocupação em aproveitar o acaso como gerador de idéias.

Aos professores doutores Shirley Paes Leme, Ricardo Hage, José Roberto de Oliveira e Ermelindo Nardim com quem pude discutir questões presentes neste trabalho.

À Profa. Dra. Norma T. Grinberg e ao Prof. Dr. Carlos Fajardo pelo upgrade A pais e filhos e ao amor incondicional.

À tia Profa. Dra. Bertha Buby Floh de Araújo, e seu academicismo "desengessado".

Aos olhos, ouvidos e palavras escolhidas do Cadu Carlos Eduardo Riccioppo

À cumplicidade do Marcelo, que constrói passado, presente e futuro, muito além da cortina preta. 

Introdução

1. quem vê, quem se vê. .13

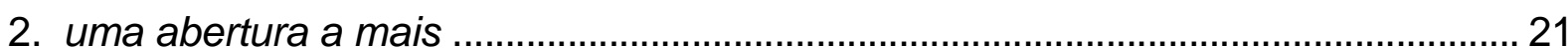

3. a cidade, a fotografia, o passante: arte e técnica ...............................................29

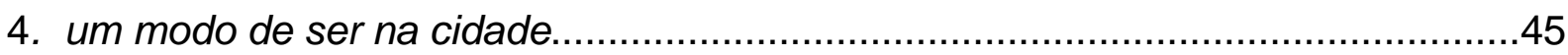

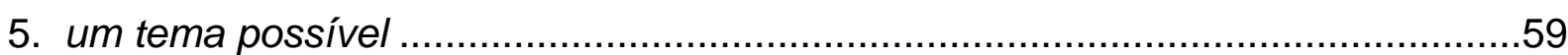

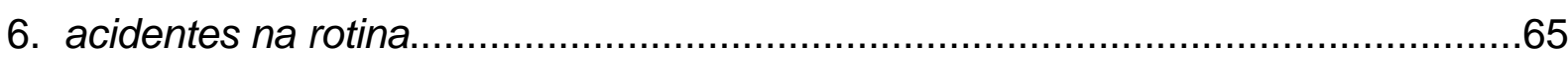

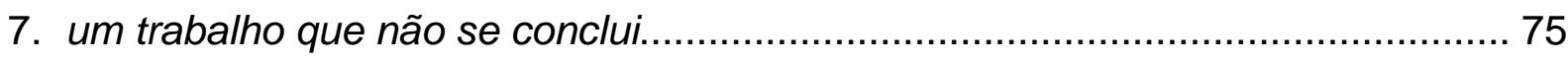

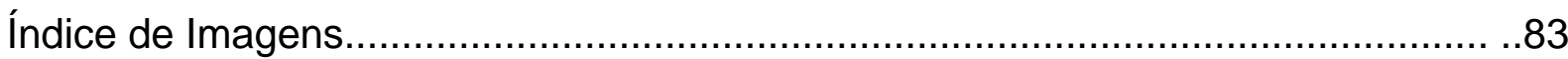

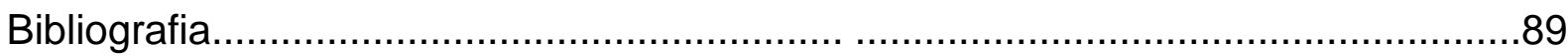

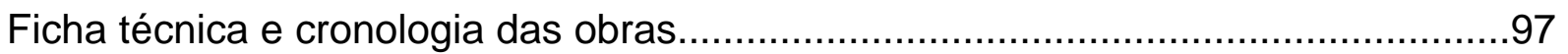



além da cortina preta é um trabalho composto de objetos que se desdobram uns nos outros: um livro homônimo dividido em dois volumes (o primeiro contém textos e registros do processo de criação de uma série de obras visuais e o segundo reproduz as mesmas) e uma mostra expositiva das obras.

O primeiro volume do livro reúne pensamentos dispersos que ocorreram ao longo de todo o percurso de criação das imagens e uma série de questionamentos originados na confluência da experimentação diária urbana e dos estudos teórico-práticos relativos à fotografia. Somam-se aí, alinhadas paralelamente, interlocuções polifônicas como poemas, músicas, notas de jornal, artigos, textos de outros autores e anotações. Ecoam uns nos outros os processos de reflexão, análise, composição, produção e criação.

O segundo volume do livro reproduz, numa outra combinação e dimensões, as imagens que compõem a mostra expositiva, cuja configuração foi concebida de forma a não ter uma primeira ou última imagem: é como se estivessem todas no meio de uma seqüência, sem começo ou final.

A mostra expositiva apresenta o trabalho visual de forma contínua, uma vez que seus segmentos unem-se lateralmente cobrindo toda a extensão das paredes da sala em que se dispõem. As obras têm dimensões adequadas a uma experimentação de deslocamento do corpo no espaço expositivo, mantendo na altura uma medida fixa; dispõem-se como um grande plano panorâmico aglutinador das muitas vistas capturadas/ capturantes - pura superfície de qualidades que se estendem ao indefinido.

Os dois volumes do livro e a exposição são complementares e constituem o corpo de minha dissertação de mestrado. 
(...) "não há senão um caminho. Procure entrar em si mesmo. Investigue o motivo que o manda escrever; examine se estende suas raízes pelos recantos mais profundos de sua alma; confesse a si mesmo: morreria, se lhe fosse vedado escrever? Isto acima de tudo: pergunte a si mesmo na hora mais tranqüila de sua noite: "Sou mesmo forçado a escrever?" Escave dentro de si uma resposta profunda. Se for afirmativa, se puder contestar àquela pergunta severa por um forte e simples "sou", então construa a sua vida de acordo com esta necessidade. Sua vida, até em sua hora mais indiferente e anódina, deverá tornar-se o sinal e o testemunho de tal pressão. Aproxime-se então da natureza. Depois procure, como se fosse o primeiro homem, dizer o que vê, vive, ama e perde. Não escreva poesias de amor. Evite de início as formas usuais e demasiado comuns: são essas as mais difíceis, pois precisa-se de uma força grande e amadurecida para se produzir algo de pessoal num domínio em que sobram tradições boas, algumas brihantes. Eis por que deve fugir dos motivos gerais para aqueles que a sua própria existência cotidiana lhe oferece; relate suas mágoas e seus desejos, seus pensamentos passageiros, sua fé em qualquer beleza - relate tudo isto com íntima e humilde sinceridade. Utilize, 
para se exprimir, as coisas de seu ambiente, as imagens de seus sonhos e os objetos de suas lembranças. Se a própria existência cotidiana Ihe parecer pobre, não a acuse. Acuse a si mesmo, diga consigo que não é bastante poeta para extrair as suas riquezas. Para o criador, com efeito, não há pobreza nem lugar mesquinho e indiferente. Mesmo que se encontrasse numa prisão, cujas paredes impedissem todos os ruídos do mundo de chegar aos seus ouvidos, não lhe ficaria sempre sua infância, essa esplendida e régia riqueza, esse tesouro de recordações? Volte a atenção para ela. Procure soerguer as sensações submersas desse longínquo passado: sua personalidade há de reforçar-se, sua solidão há de alargar-se e transformar-se numa habitação entre lusco e fusco diante da qual o ruído dos outros passa longe, sem nela penetrar. Se depois desta volta para dentro, deste ensimesmar-se, brotarem versos, não mais pensará em perguntar seja a quem for se são bons. Nem tão pouco tentará interessar as revistas por esses seus trabalhos, pois há de ver neles sua querida propriedade natural, um pedaço e uma voz de sua vida. Uma obra de arte é boa quando nasceu por necessidade. Neste caráter de origem está o seu critério, - o único existente.” (...) (Rilke, 1989. p 22 - p. 24) 


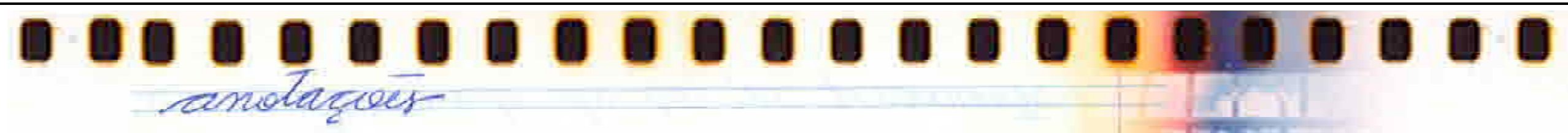 \\ Un outro modo de ser no pensamento

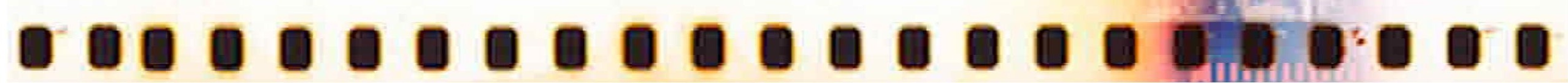


Embora manifestamente atrelada aos registros documentais e ulterior análise dos procedimentos poéticos/ plásticos de um trabalho que vem se desenvolvendo ao longo dos últimos anos e, portanto, aberta aos seus desvios e desencontros e operando neles ainda outros desvios e encaminhamentos, esta reflexão não pretende ser mais do que um mapa indicativo das formas pelas quais o trabalho, aqui apresentado, condensa uma experiência singular na cidade. Essa experimentação, que nada tem de incomum, uma vez que se dá muito arraigada aos trajetos rotineiros mais ou menos previsíveis de um habitante qualquer, compõe, no entanto, uma estranha e caleidoscópica perspectiva desse viajante urbano.
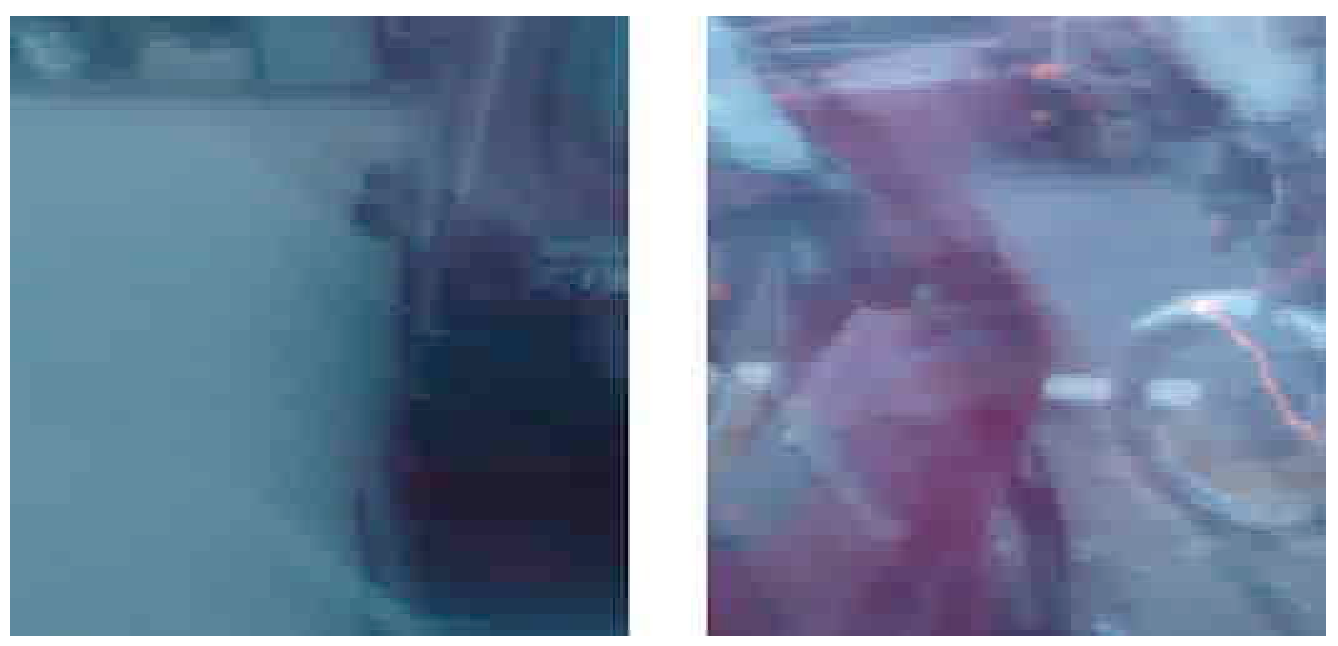

imagem 1 - visões passageiras de um passante

Thanio de Andrade disse cuma vey gue a acte nat

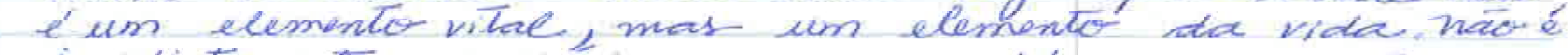
impdiatamente necersalia como comida, raupas, trauporte

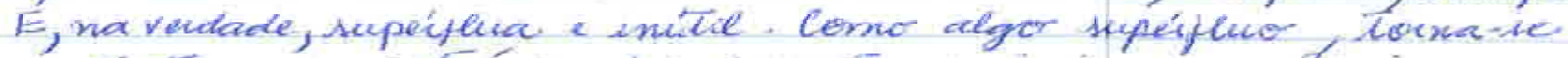

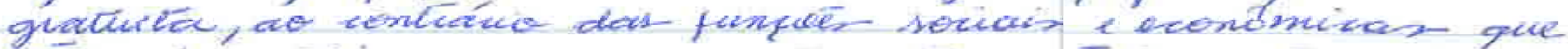

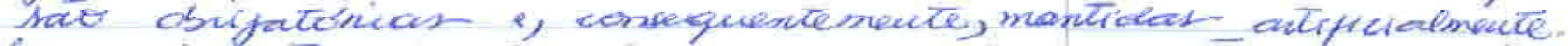

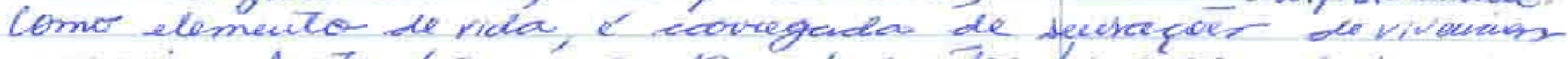

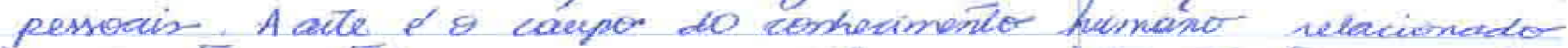

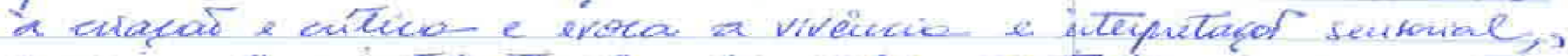

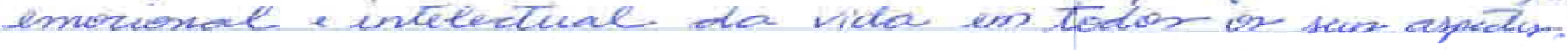


Essa perspectiva, resultado de percepções inusitadas do espaço urbano, é do tipo imersiva e reflectiva. Especularista, ela traduz a captura de imagens, com câmeras fotográficas (analógicas e digitais ${ }^{1}$ ) e sua subseqüente manipulação digital2 ${ }^{2}$ em fabulações visuais.
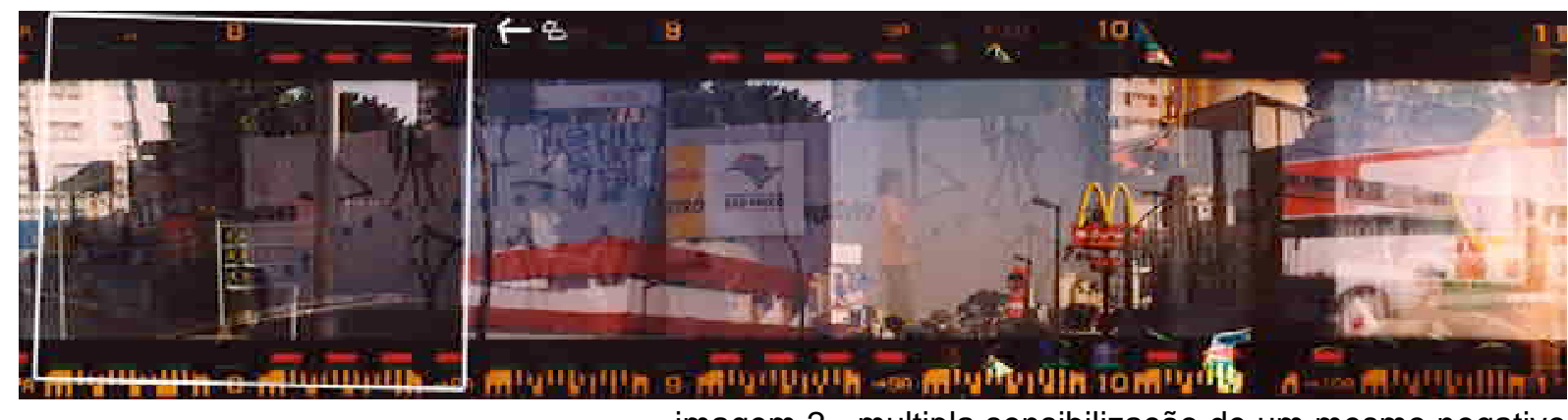

imagem 2 - multipla sensibilização de um mesmo negativo

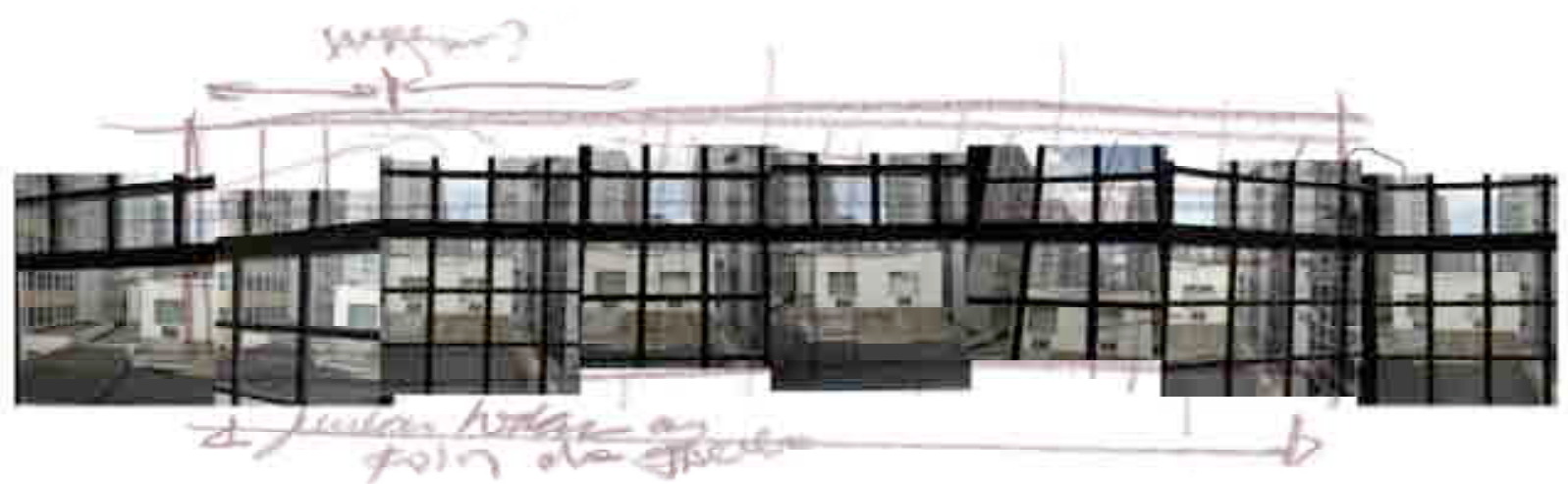

imagem 3 - justaposição: montagem em computador

1 As câmeras usadas ao longo do processo deste trabalho são: Rolleiflex SL35, Hasselblad $500 \mathrm{c} / \mathrm{m}$, Sony Cyber-Shot, Nikon D70.

2 Os softwares utilizados são específicos para a edição de imagens e de textos, tais como o Adobe Photoshop e o QuarkXpress.

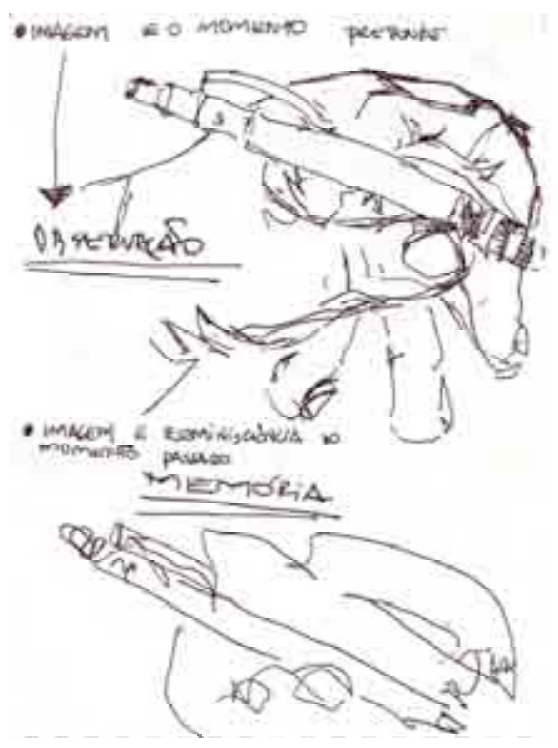


Foram as inquietações, indagações, devaneios e vertigens que decorreram das experimentações, acima referidas, aquilo que compôs o livro (dividido em dois volumes) e a exposição de painéis "fotográficos" (obras visuais resultantes das operações que serão aqui descritas), ambos intitulados além da cortina preta.

No primeiro volume do livro reuni, em texto, uma série de pensamentos dispersos que se deram ao longo de todo o desenvolvimento dos trabalhos visuais. São ressonâncias de tipos variados e também questionamentos sobre o real momento de finalização das obras, pois essas modificam-se a cada concretização material, a cada nova impressão.

A reflexão sobre os planos conceituais amigos, sobre poetas, a cujas famílias gostaria de pertencer, o destaque de algumas anotações esclarecedoras, e, finalmente, os esquemas processuais traçados, encadearam os capítulos do primeiro volume e, paralelamente, soldaram o texto um outro modo de ser no pensamento, localizado na parte inferior das páginas.

Em quem vê, quem se vê (cap. 1) indago sobre uma cidade que quer ser vista e precipita-se em formas dialógicas de enunciação, rompendo com os pressupostos preestabelecidos e abrindo caminho para que elementos

"Que importa a paisagem, a Glória, a baía, a linha do horizonte?- o que eu vejo é o beco." Poema do beco de Manoel Bandeira

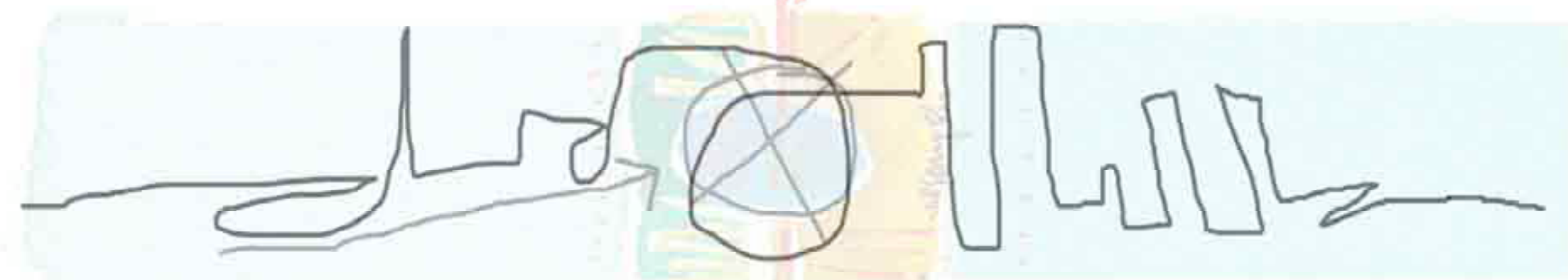


imagéticos urbanos adquiram fala. Uma relação constante entre capturar imagens e ser capturada por elas é o que apresento em uma abertura a mais (cap. 2), momento em que descubro, no alinhamento de uma espécie de consciência externa ao meu corpo - as máquinas fotográficas - 0 desenvolvimento de uma abertura a mais para a minha "conexãodissolução" no entorno urbano. a cidade, a fotografia, o passante: arte e técnica (cap. 3) traz uma abordagem empática de relações conceituais que se estabelecem historicamente entre a fotografia e a cidade, baseada sobretudo em estudos de Walter Benjamin, Meyer Schapiro e Félix Guattari. Trata-se, em outras palavras, de uma discussão que tangencia o meu encontro simpático com alguns autores referenciais da história da arte. É dessa maneira também que, em um modo de ser na cidade (cap. 4), reflitome na figura do flâneur e, com ela, compreendo-me submersão e infiltração como forma de pertencimento à cidade. Já dissolvida na cidade, em um tema possível (cap. 5), busco recompor, no discurso, as sentenças visuais que compõem meus trabalhos; tento encadear, com palavras a minha experiência traduzida em imagens articuladas - paisagens possíveis.

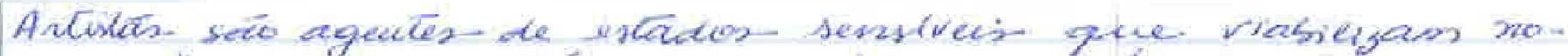

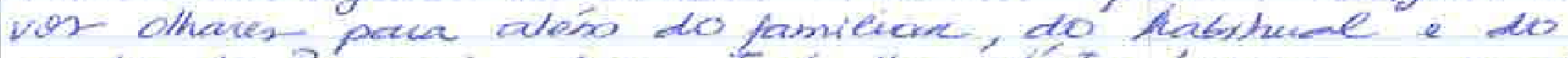

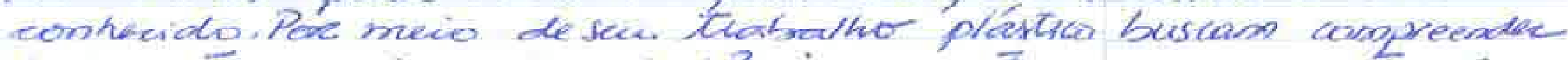

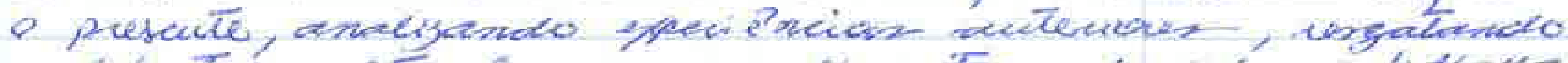

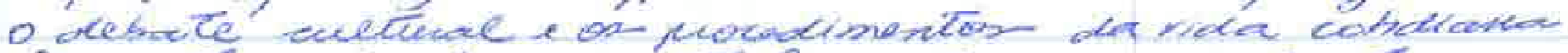

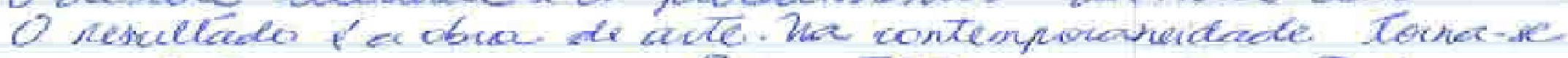

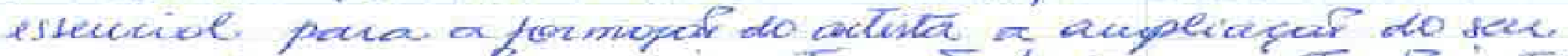

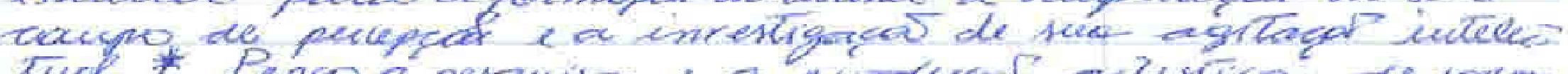

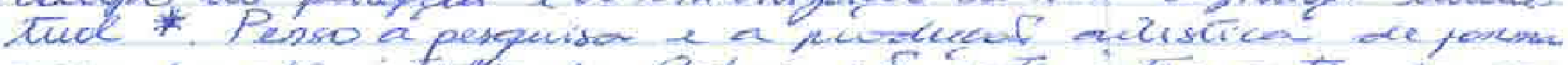

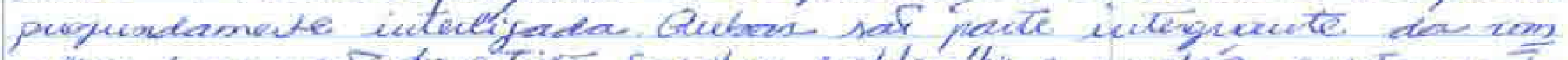

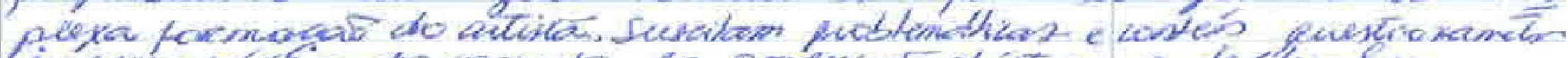

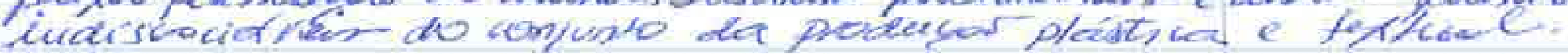

* a esse respeito, o professor e artista plástico Geraldo Ortthof escreve: "A aprendizagem estética constitui uma forma de investigação intelectual e sensorial que estabelece códigos para um modo especifico de linguagem. O olhar contemporâneo não se esgota nos valores outrora consagrados como virtuosismo técnico, a auto-expressão, a beleza, a originalidade ou o prazer. Nessa busca constante pela ampliação de seu campo de sentidos, o artista exercita um aprofundamento teórico sin gular na percepção e registro do mundo à sua volta." (Brites, 2002, p.79) 
acidentes na rotina (cap. 6) reconstitui o permanente processo de refluxo e absorção dos acidentes, erros e acasos que vão constituindo, muito aos poucos, o modo de confecção próprio do trabalho. Vejo, enfim - em um trabalho que não se conclui (cap. 7) -, ecoarem o contínuo processo de composição e recomposição das imagens deste trabalho e da cidade.

O segundo volume do livro é uma versão bibliográfica da obra visual além da cortina preta, um exemplo próprio da inquietação de um trabalho que não se finaliza, que não se esgota em suas exibições, que se modifica em cada uma de suas atualizações.

A mostra expositiva é formada pelo conjunto dos painéis "fotográficos", cuja característica sintática é a sempre renovada combinação de suas partes, pois o espaço de exibição é componente estrutural do trabalho, determinante de seu suporte e das suas dimensões ${ }^{3}$. Não há a primeira ou a última imagem - todas são no meio.

3 Há, talvez, algo nesses trabalhos de uma discussão pertinente à pintura, sobretudo no uso das cores e nos grandes formatos que o trabalho adota em certas maneiras de se expor. Isso talvez esteja enraizado nas pinturas anteriores a esses trabalhos de fotografia que, sem que possuíssem um tema mais ou menos definido, aconteciam como uma pergunta sobre o comportamento da cor na cidade e na arquitetura.
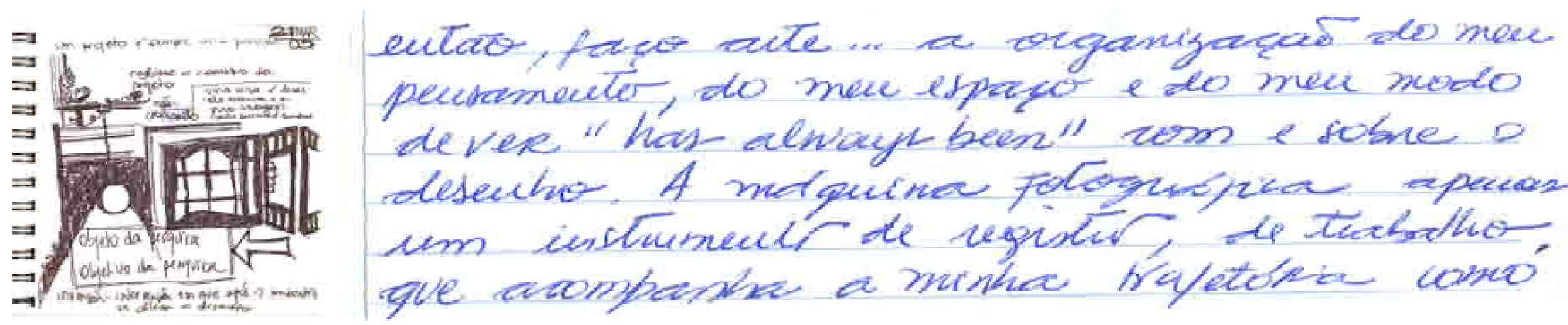
Por fim, essa investigação forma uma paisagem não-real, uma cidade oculta, decorrente de operações executadas com o quadro e a cortina da câmera. A cidade apenas se vislumbra atrás, sugere sua presença sem jamais se figurar por inteiro.

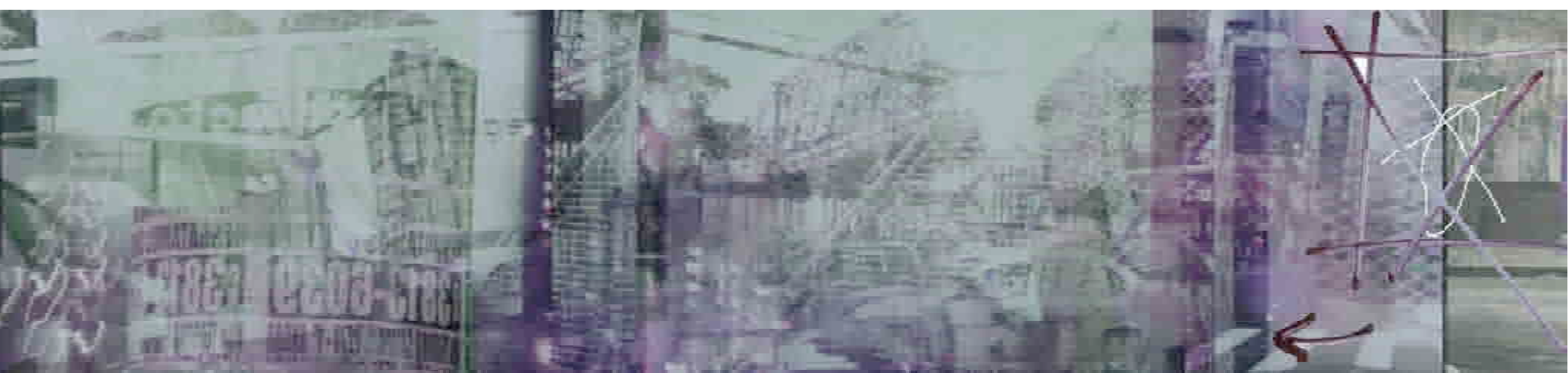

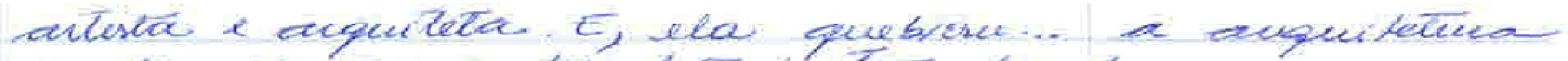

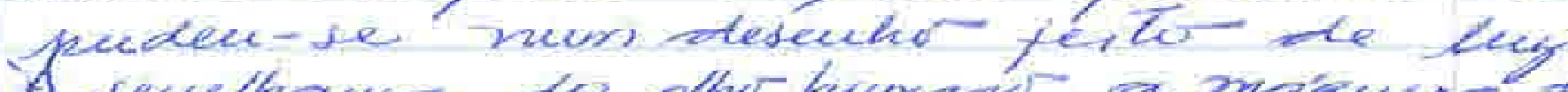

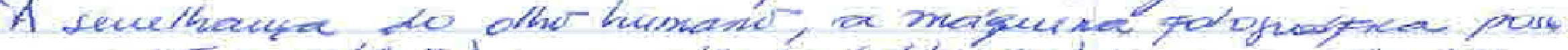

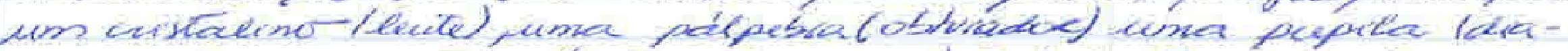

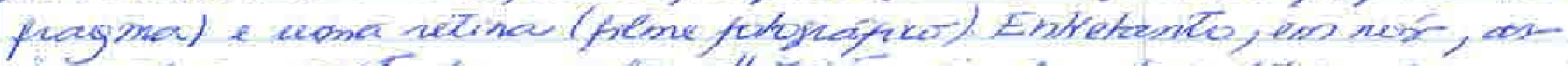

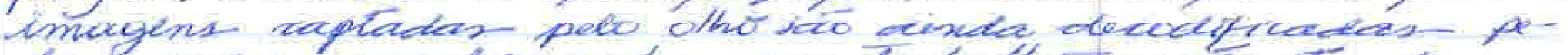

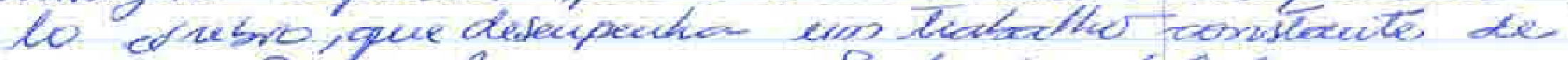

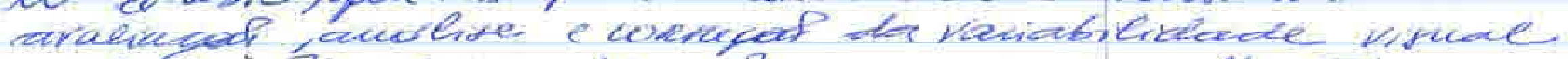

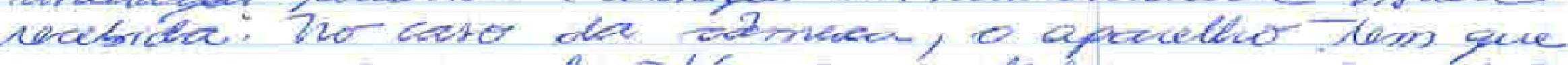

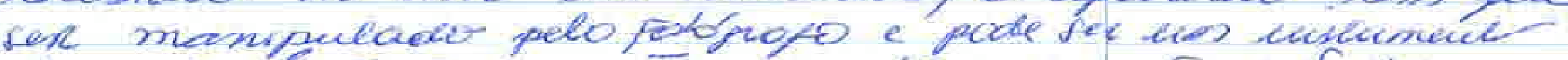

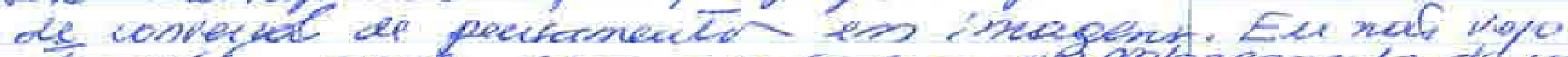

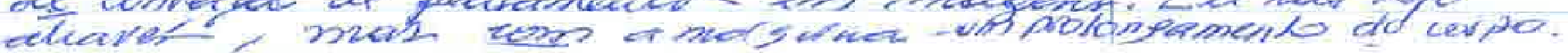





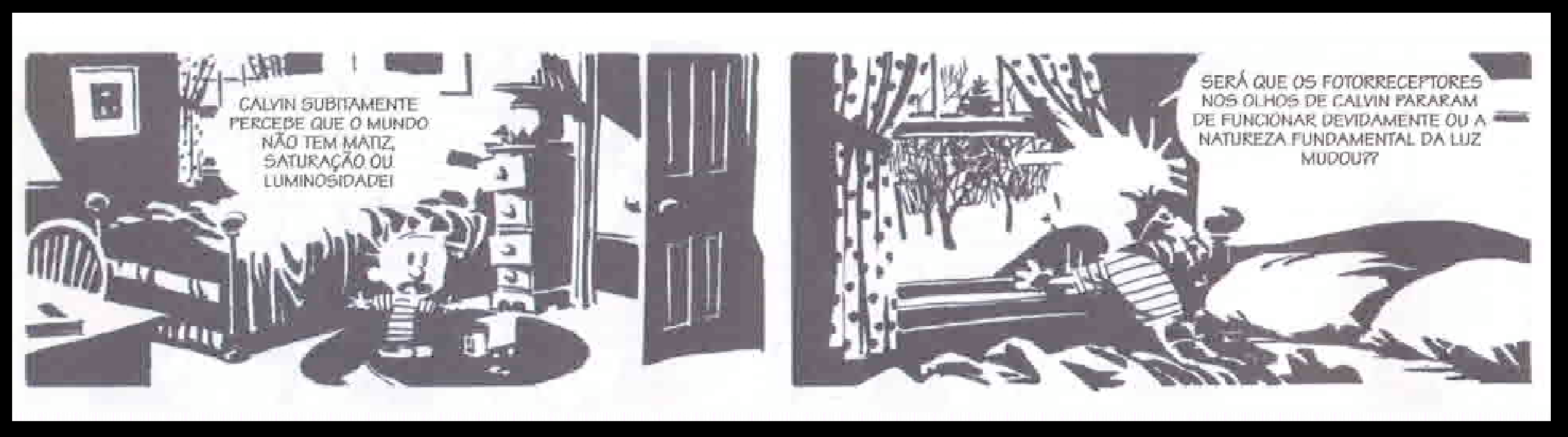


TALLEZ ALGUMA ESTRANHA REACTO NUCLEAR OU QUIMICA NO SOL. TENHA PROVOCADO QUE A RADIACXKO ELETROMAGNÉTICA DESAFIE A SEPARACĀO NUM FSPECTROI

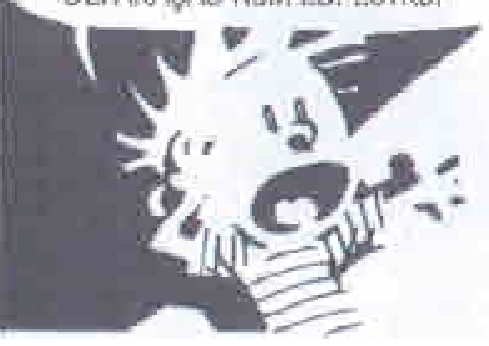

TAL.VE2 OS OBJETOS NXOO REFLITAM MAIS CERTOS COMPRIMENTOS DE ONDAJ QUALQUER QUE SEJA A CAUSA. ESTŔ CLARO PARA CALVIN QUE NÄ́O ADIANTA DISCUTIR, AS COISAS COM O

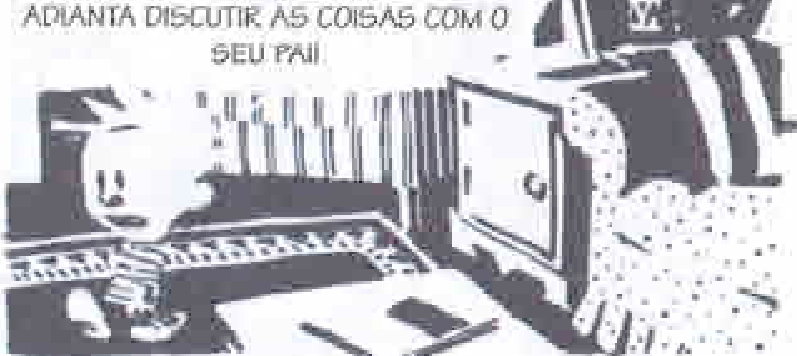

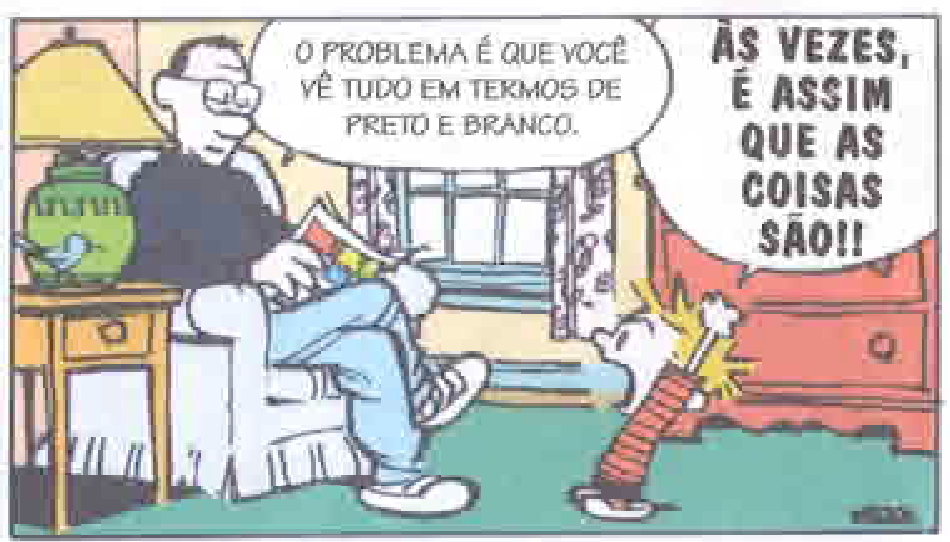




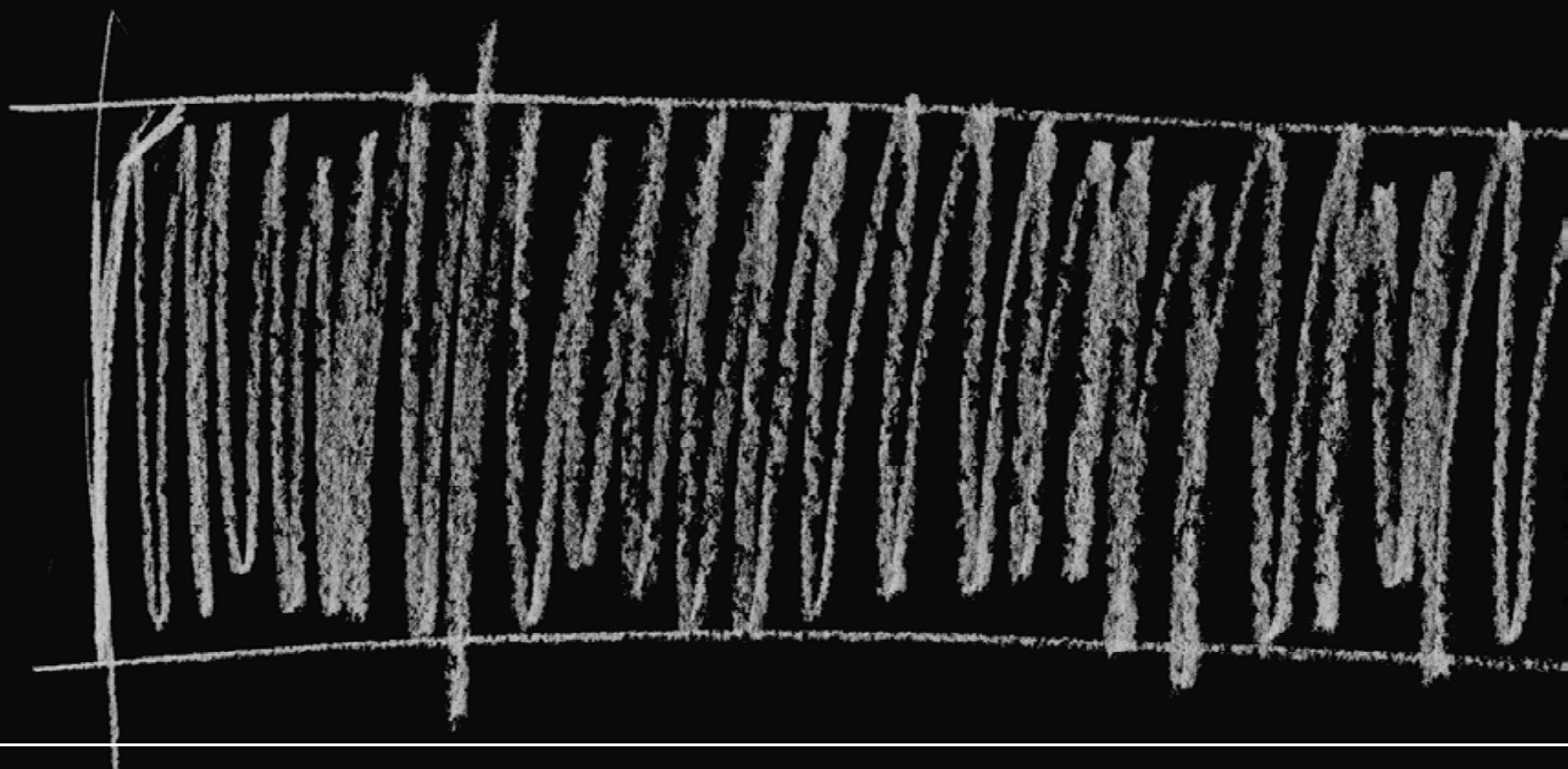


"O que vemos só vale - só vive - em nossos olhos pelo que nos olha. Inelutável porém é a cisão que separa dentro de nós o que vemos daquilo que nos olha" 4

É o passante/ espectador, aquele que participa dos planos visuais abordados nos trabalhos ou não seria ele, igualmente, um agente produtor de imagens que, em sua rotina, também constitui imagens da cidade?

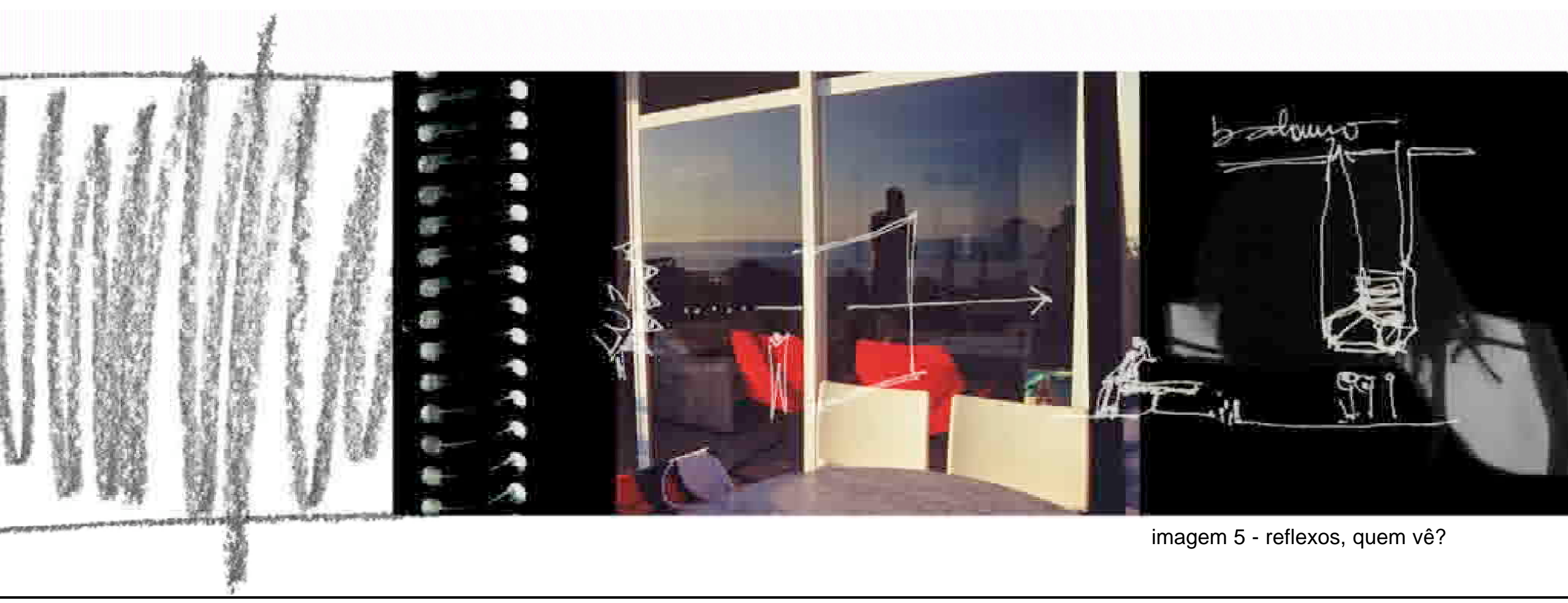

4 Georges DIDI - HUBERMAN, O que vemos, o que nos olha, p.29

Observar, olhar, ver, enxergar, para descobrir o interno e o externo, através do aparelho, para descobrir poten cialidades ignoradas no meu caminho, para revelar as potencialidades do espaço urbano que habito e imagens da cidade que me afetam. Quem se vê nas rondas urbanas? Quem vê essas imagens? Se o espectador é aque le que participa dos planos visuais abordados no trabalho, então ele tende a se assemelhar, em importância, a um poste ou a uma placa. Mas, se ele, assim como eu, é alguém que, em sua rotina, também constitui imagens da cidade, não há nada neste trabalho que mereça um outro tipo de consideração... Esse usuário/ espectador está num eterno movimento cada vez mais rápido - visto de dentro do carro, o mundo lá fora voa: o poste funde - se com o muro, a calçada está na janela. A velocidade provoca um achatamento da paisagem: tudo é fachada. Esse olhar efêmero transforma a paisagem urbana num outdoor e então, o olhar já não dá conta da paisagem. 
Tudo aquilo que me despertou a atenção durante a criação deste trabalho a visualidade da cidade - coincide com aquilo que constitui o mundo dos interlocutores, em cujos diálogos me vi e ouvi: outdoors, placas de trânsito, faixas de pedestre, carros, luzes de néon. Tudo isso quer conversar comigo de maneira violentamente narcísica, ansiosa e acelerada. Quer chamar a minha atenção, exibindo-se descaradamente. A cor muito esperta assaltame de surpresa, a vibração rítmica muito forte segura-me, uma beleza e uma feiúra especiais espantam-me, o outdoor silencioso chama: "Psiu!", homens gigantescos e mulheres/ deusas oferecem suas intimidades, o farol grita "Pare!", "Cuidado!" - e, no entanto, nada pára.

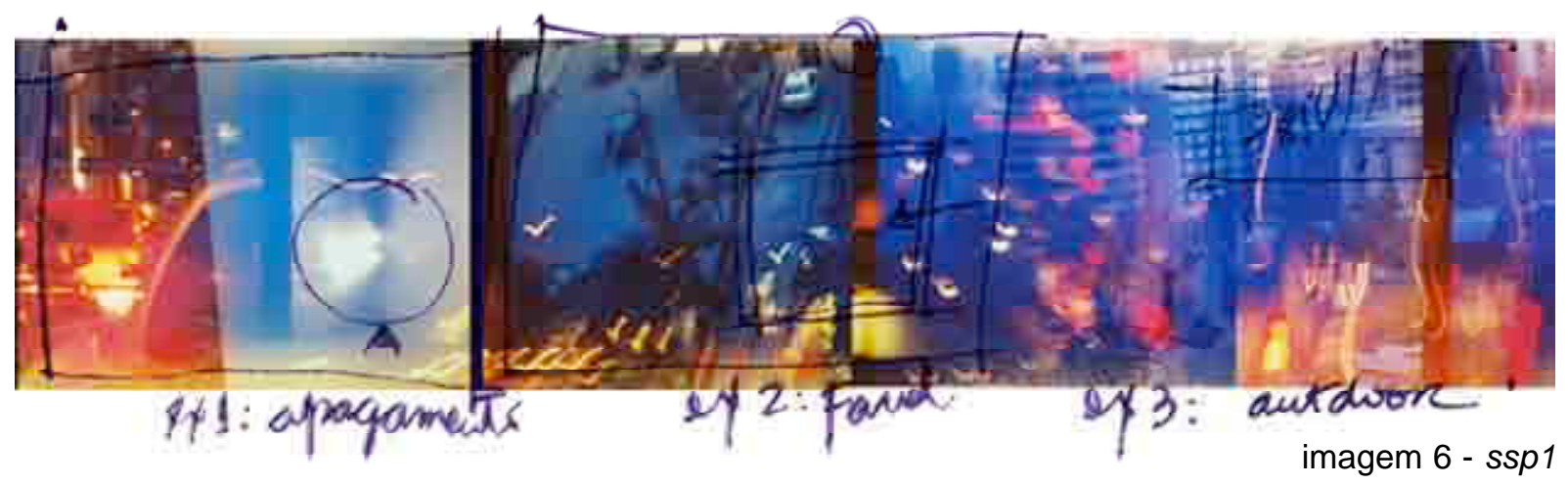

pensamento rápido com Barthes.... Para Roland Barthes a foto é uma imagem fundamentalmente difer ente das outras imagens pois realidade e passado estão nela: o que ela representa esteve ali - isso existiu - "a fotografia é o próprio traço do que representa: é a luz emitida pelo objeto ou pela pessoa fotografada que vem marcar o filme e fundir o nitrato de prata (...) Se esse real existiu, é porque não existe mais, e a fotografia torna-se o próprio signo de que somos mortais". Portanto, a foto é a pre sença de um ser que está ausente e que nunca mais será assim. As minhas fotos perdem essa característica no momento em são digitalizadas (e são digitalizadas para a manipulação de propriedades como cor, saturação e do formato de impressão). De qualquer forma, a seleção feita por um fotógrafo torna-se, muitas vezes, a única referência ao passado esquecido, pois a imagem fotográfica pode transportar-nos de um tempo cronológico a um tempo memorial afetivo, onde as lembranças fixadas na imagem substituem pessoas e acontecimentos reais que se perdem. 
Longe de abordar os elementos da cidade apenas como "coisas visíveis", pretendo abordá-los como "coisas vivíveis", numa relação dialógica, e esse é o ponto principal aqui: até onde os elementos da cidade, sobretudo os mais salientes suportam ser confrontados entre si ou, de outro modo, até que ponto esses mesmos elementos, que só existem como vontades de serem vistos, mantêm-se em seu programa diante de outros iguais a eles? Que espécie de experiência formativa está envolvida na sua disputa pela primazia na interlocução? Que tipo de experiência é esta na cidade ou na visualidade da cidade, segundo a qual somos convocados a "interagir" somente como um alvo visual?

A reflexão tem início na abordagem simultânea da cidade e seu registro fotográfico. Pretende-se apontar um modo de produção que está, antes de qualquer outra coisa, conectado aos episódios e acontecimentos da rotina de alguém que, em suas andanças pela cidade, porta uma máquina fotográfica como um prolongamento protético de seu corpo, um olho mecânico, às vezes eletrônico também, acoplado aos outros dois orgânicos.

Não tenho a intenção de transportar ninguém à lugar algum, mas nas minhas imagens, as lembranças do lugar fotografado também já não existem, esse lugar é um não lugar. Neste lugar/não lugar vive-se uma eterna corrida, as entradas e saídas escondidas nas dobras do tempo que escorre por entre os dedos e desmancha-se no melhor instante do presente. Resta apenas o tempo da duração, multilin ear, paradoxal e flutuante, o tempo de acontecimentos e devires, e é nesse tempo apreendido intuiti vamente e não como sucessão temporal, que a cidade respira. Nutre-se da energia que seus agentes e usuários fornecem para alimentar a sua auto-transformação. (Para Bergson, o tempo é a idéia matemática que fazemos da duração para raciocinar. A duração só pode ser apreendida pela intuição. A duração é uma realidade concreta, a trama mesma do devir da consciência, que só pode existir como tal, caso se lembre de seu passado, mas que é reinventando a cada instante para adaptar-se ao presente. (dicionário básico de filosofia, p.76) 
Poder-se-ia dizer, inicialmente, que a cidade ou, as visões que se tem do espaço urbano, constituem o núcleo formador do trabalho, uma vez que, de fato, todo o processo de fabricação das imagens que compõem além da cortina preta começa com uma operação material que é o registro fotográfico da cidade. Essa primeira visão que a máquina captura dissolvese nas visões posteriores, num processo de "apagamento" por acúmulo e sobreposição.

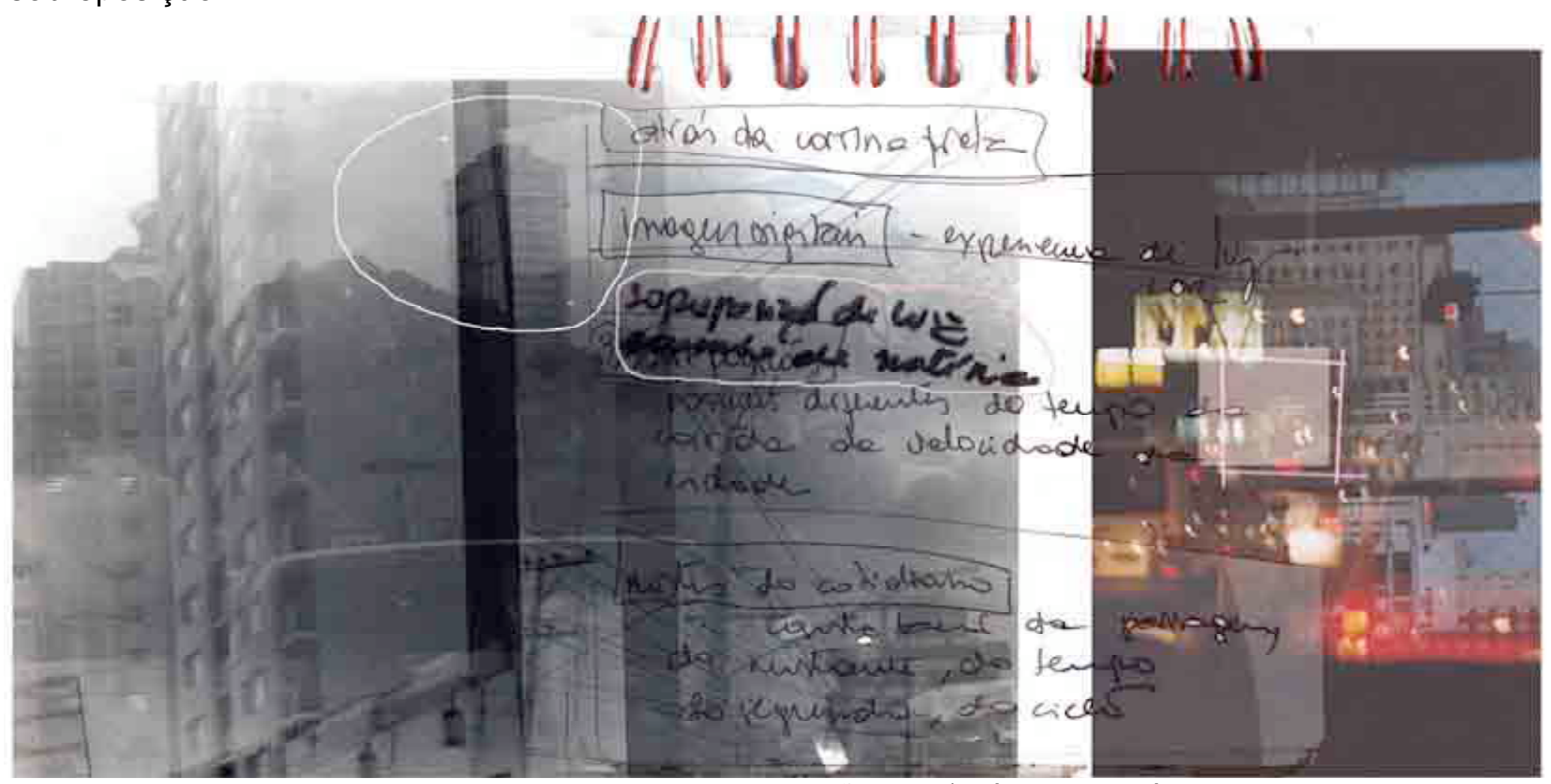

imagem 7 - sobreposição de luz/ acúmulo de matéria

\section{A CIDADE por TataAmaral}

"Viver numa cidade como São Paulo é viver uma experiência singular: São Paulo não é uma cidade acolhedora. Não é uma cidade que se distingue por sua paisagem natural, por sua musica ou festas. Nos roteiros turísticos se destacam grandes edifícios, restaurantes, vida noturna, bares, boates e cafés, cinemas e teatro. Se você quer simplesmente encontrar um amigo, sua opção é ir à sua casa ou entrar num restaurante ou bar e ... consumir. Nada de encontros em espaços abertos. Resultado: os que estão fora da sansara do consumo são marginalizados e vítimas de preconceitos. São Paulo não é uma cidade feita para pedestres que são constantemente ameaçados por veículos tresloucados. Aqui não existe o flâneur. Não há passeios públicos possíveis. Os poucos parques e praças de que dispomos estão trancafiados atrás do medo da invasão dos pobres, do medo do vandalismo e do roubo. São Paulo é a cidade mais antimodernista que conheço: todos os seus espaços são privados ou trancafiados. A utopia modernista foi degradada em poucas décadas, confinada por algumas toneladas de ferro e cimento. A rua, por sua vez, é fria, inóspita, esburacada.São Paulo não é bela. A tentativa de lê-la através do pós-modernismo cai por terra assim que "viramos nossa câmera" para outro lado. Apenas um ou outro recanto isolado se presta a esta leitura. O todo é um emaranhado confuso de fios, grades, casas mal- 
Os caminhos diariamente percorridos com as câmeras fotográficas implicam em passar pelos mesmos lugares e fotografá-los, em momentos e dias diversos, de modo que a rotina objetivada na fotografia é permeada por vivências pluridimensionais concomitantes, desde as espaciais até as temporais e corporais. Fica impossível restituir qualquer cronologia, pois o filme vai e vem registrando momentos distantes, fisicamente, mas próximos quando sobrepostos na película, de modo que qualquer ponto do negativo pode ser o começo, o meio, ou o fim. Assim, sem que se proceda a uma ordenação prévia, toda seqüência temporal é arrebentada pelos deslocamentos espaciais aleatórios do filme na máquina.

O objetivo determinante da série além da cortina preta é a fabulação dos vários temas/ personagens/ cenas, obtida por meio de operações poéticas sobre os registros fotográficos de qualidades e intensidades singulares, fixadas na película fotossensível e da qual nenhuma "informação" pode ser extraída, pelo contrário, que só como contra-informação pode ser experimentada.

acabadas, muros pichados, anúncios, luminosos ou não, que se amontoam e se tornam ilegíveis, assim que saímos dos poucos bairros residenciais de classe media da cidade. O acesso às escassas áreas verdes é complicado, requer transporte particular ou - os também escassos e pouco práticos - transportes públicos. São Paulo dá a impressão de ser uma cidade construída a partir da idéia de funcionalidade imediata. $A$ beleza não tem lugar aqui. No entanto, ao visitarmos os livros de iconografia do povoado, no século passado, encontraremos um amontoado de casas construídas entre rios numa região de uma beleza topográfica incrível. O que foi feito desta antiga beleza natural? Quando e como a geografia foi homogeneizada com a construção de edifícios de qualidade operacional e estética duvidosa? Não há mais bairros que guardem características específicas de ocupação ou população. Com exceção das favelas e áreas de ocupação não-urbanizadas, que guardam características próprias, São Paulo está homogeneamente ocupada por construções de suaves prestações que arranham o céu da cidade. Em todas as cidades do mundo a região urbana às margens do rio tornou-se nobre. Aqui é o nosso ponto mais degradado: rios mortos com margens adulteradas e degradadas. Qual a verdade desta cidade? São Paulo não é uma cidade humana. Mais Parece uma máquina improvisada, construída com sucatas e arames ligando um pedaço ao outro, trocados conforme a necessidade imediata." 


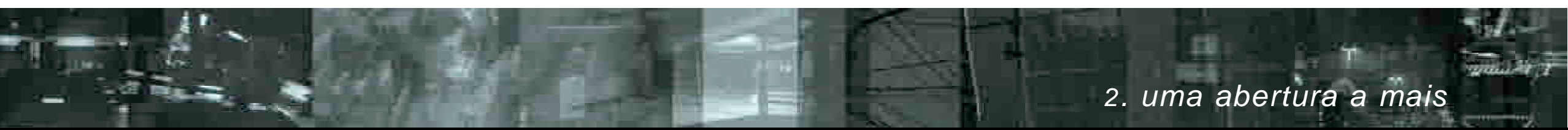

por igual. O primeiro da fila do meio está parado, deve haver ali um problema mecânico qualquer, o aceler ador solto, a alavanca da caixa de velocidades que se encravou, ou uma avaria do sistema hidráulico, blocagem dos travões, falha do circuito eléctrico, se é que não lhe acabou simplesmente a gasolina, não seria a primeira vez que se dava o caso. O novo ajuntamento de peões que está a formar-se nos passeios vê o condutor do automóvel imobilizado a esbracejar por trás do pára-brisas, enquanto os carros atrás dele buzinam frenéticos. Alguns condutores já saltaram para a rua, dispostos a empurrar o automóvel empanado para onde não fique a estorvar o trãnsito, batem furiosamente nos vidros fechados, o homem que está den tro vira a cabeça para eles, a um lado, a outro, vê-se que grita qualquer coisa, pelos movimentos da boca percebe-se que repete uma palavra, uma não, duas, assim é realmente, consoante se vai ficar a saber quan do alguém, enfim, conseguir abrir uma porta, Estou cego"(...) José SARAMAGO, Ensaio sobre a cegueira,pp.11/12 
cidade [Do lat. civitate.] "Cidade é a expressão palpável da necessidade humana de contato, comunicação, organização e troca, - numa determinada circunstância físico-social e num contexto histórico" (Lúcio Costa: Registro de uma Vivência, p.277) 
Para mim, estar na cidade significa sempre capturar imagens e ser capturado por elas, numa mesma luz de longe e para longe - deslocamento lateral, panorâmico, em busca de um "entre-imagens".

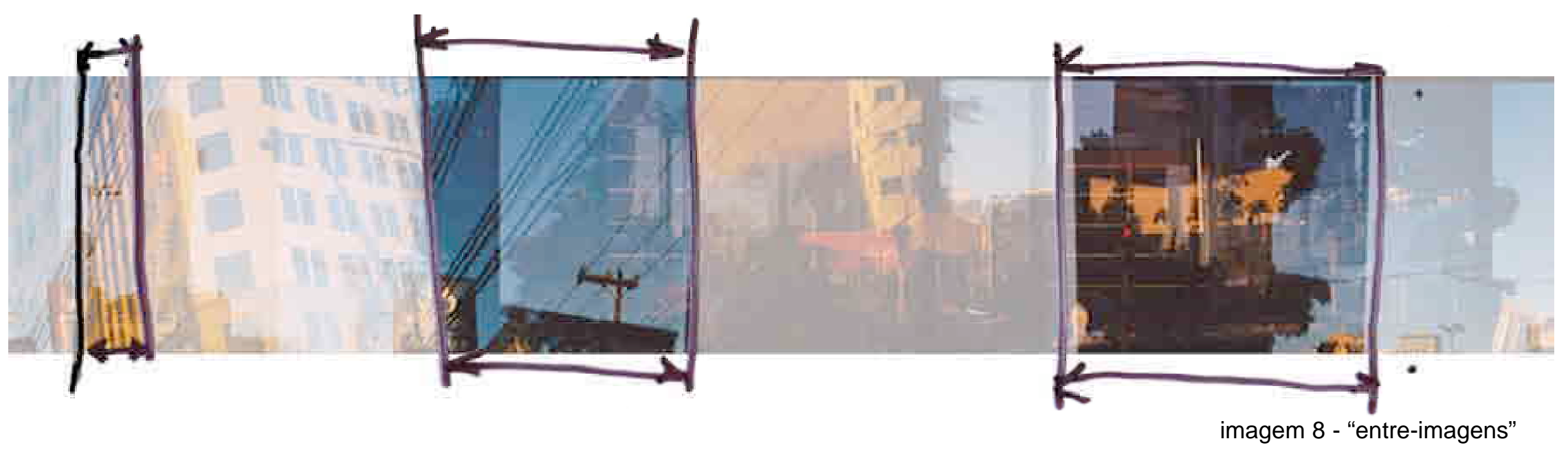

É fundamental salientar que o trabalho é menos uma avaliação que o testemunho de um modo de ser com a cidade. Eu invento a cidade, ao mesmo tempo em que ela me inventa: somos conglomerado de casas, somos espaço tomado por cartazes e outdoors e, sobretudo, somos trânsitos que agenciam acontecimentos. É justamente a captura das das
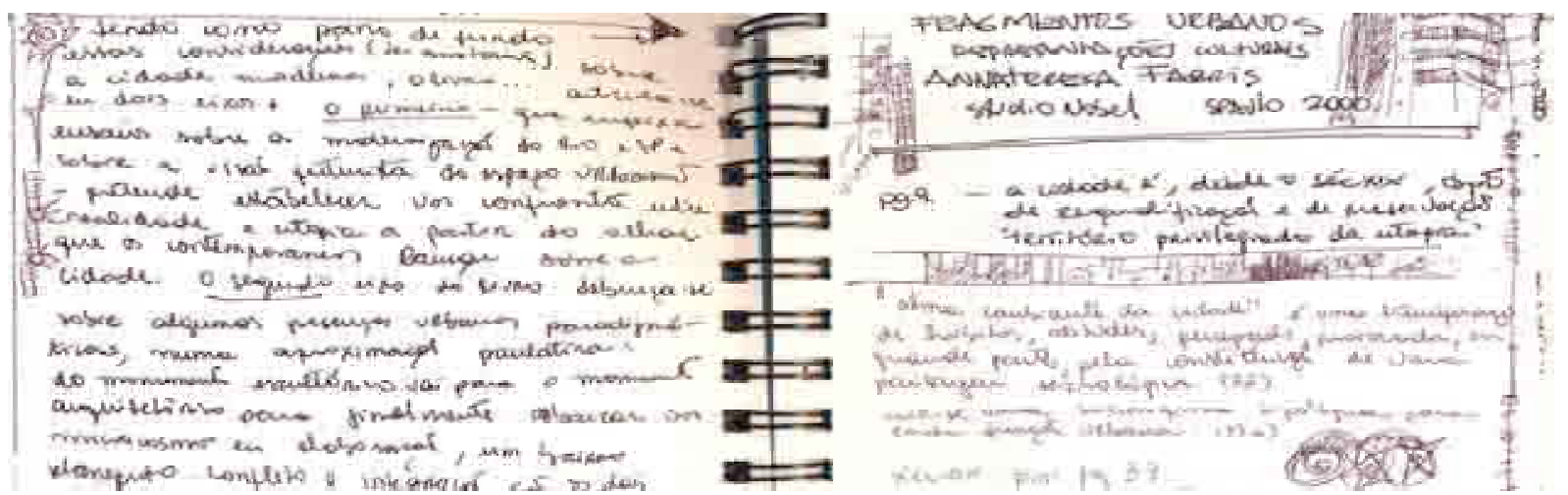
imagens nessa espécie de bagunça, e as sobreposições pós-produzidas somadas aos tratamentos em computador por meio de programas de manipulação de imagens, aquilo que no trabalho, revela, não as imagens de mim mesma, mergulhada na cidade, ou as de uma jornada na cidade resguardadas em minha memória "exterior", mas um conjunto de sensações de um modo de ser que é, ao mesmo tempo, meu e da cidade, indistintamente, e que não para de se inaugurar: um eu nascido de fora, tornado cidade.

Direi inicialmente que, diferentemente de um transeunte qualquer na cidade, a minha experiência inclui o uso permanente de uma ou mais máquinas fotográficas para o registro e a captura de imagens e essa especificidade é fundadora de uma perspectiva individual, que talvez signifique 0 desenvolvimento de uma espécie de "consciência externa do corpo", ou a criação de uma abertura a mais para o mecanismo de "conexão" "dissolução" no entorno urbano.

Não é o espírito de conservação histórico, jornalístico ou cronista da cidade que agencia as operações para a produção de além da cortina preta, mas, ao contrário, a força de variação e transformação que move o cotidiano

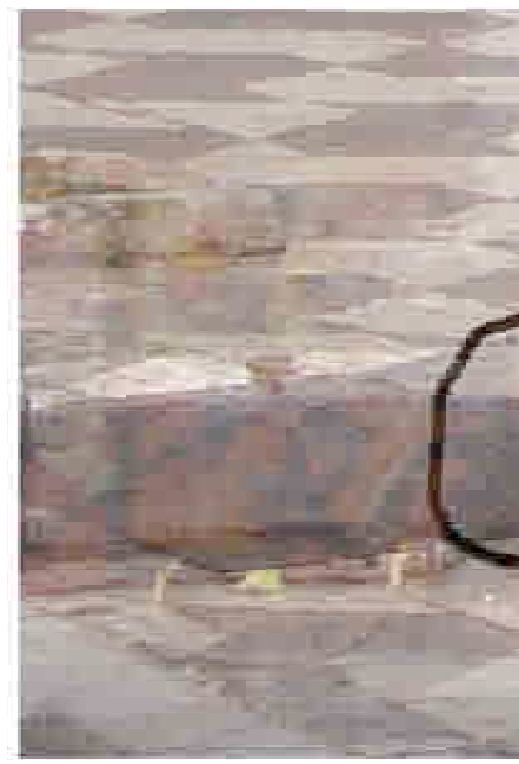
urbano, mais do que comum, e que dissolve tudo que nele penetra. É a

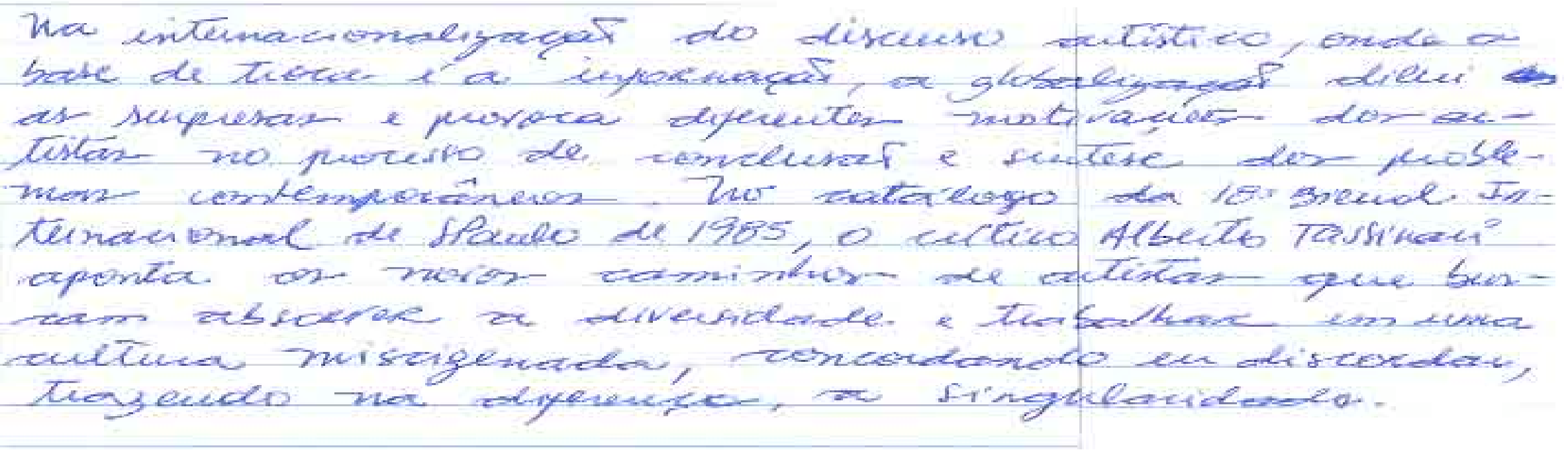


potência liquidificadora da cidade, que me faz contraída e dissolvida em seu turbilhão diário, diariamente a cidade me dá à luz.

Não é só a escrita de um outdoor, o detalhe de um edifício, a curva de um viaduto, o trecho de um poste, o farol aceso, mas também as rachaduras, os esburacados de uma calçada e outras degradações, o que faz irromper um campo afetivo de nova luminosidade, que apenas se infiltra.
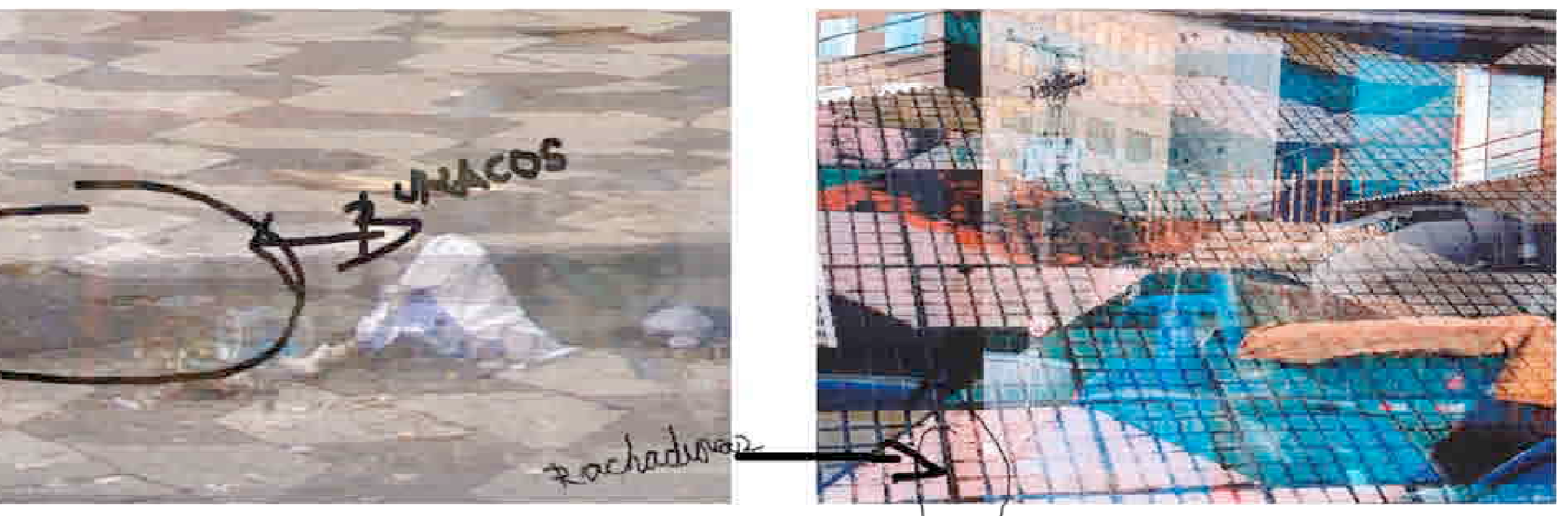

imagem 9 - um "que "de cidade

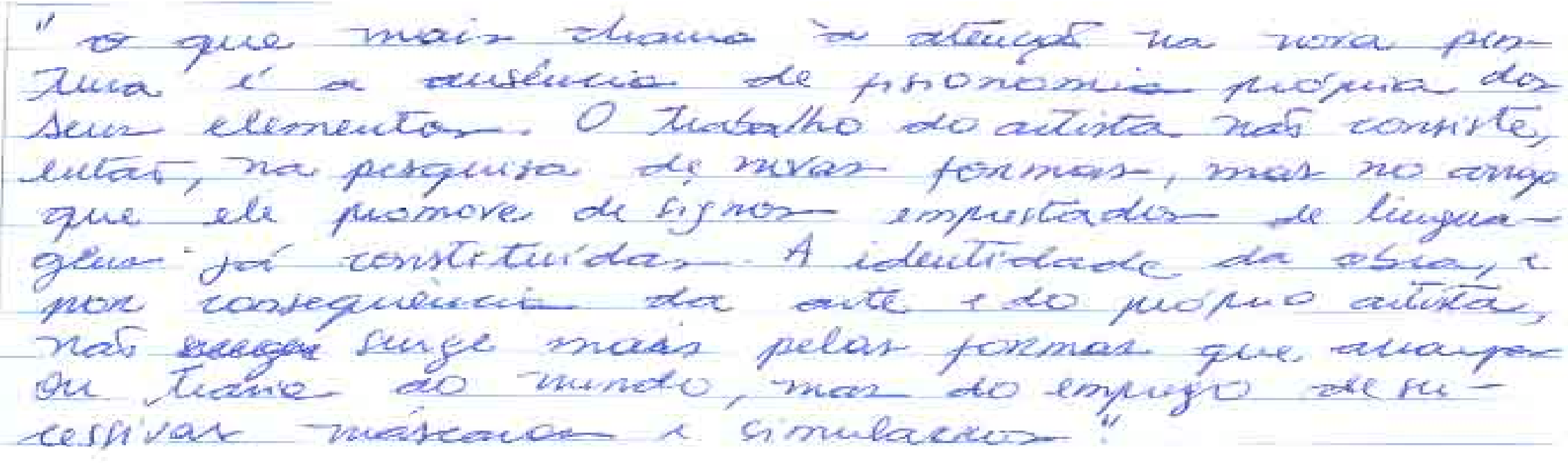


"Passar pela cidade" ou "estar na cidade" são ações que, na vasta historiografia artística brasileira e internacional, ao menos nesses últimos dois séculos, problematizam-se continuamente, como se pode ver nas obras de Toulouse Lautrec, Degas, Monet, Hopper, Volpi, Goeldi e de tantos outros artistas. É no personagem do flâneur, porém, tal como fora erigido por Baudelaire e discutido por Walter Benjamin, que acredito encontrar uma ressonância maior para essas reflexões, ou um solo sobre o qual possa mover-me mais livremente amparada, do que marcadamente influenciada. É na figura do flâneur que essa discussão, de um modo ou de outro, ver-se-á balizada daqui por diante, como uma inspiração para o sentido de ser/ estar com a cidade.
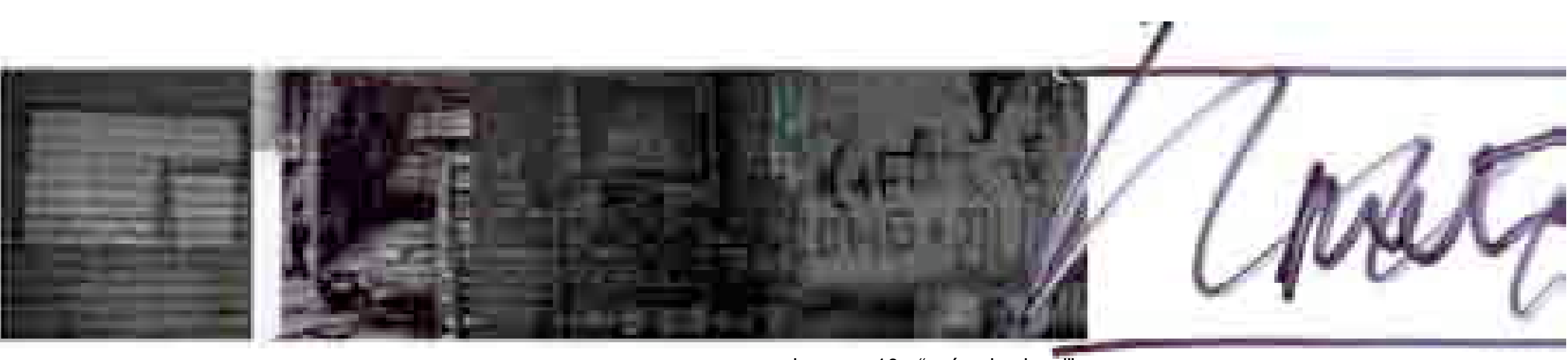

imagem 10 - "acúmulo visual" 


is

$\cos 3$

Ge

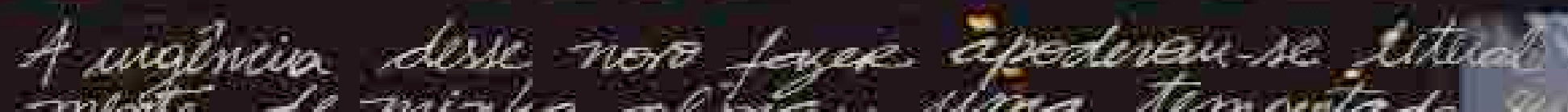

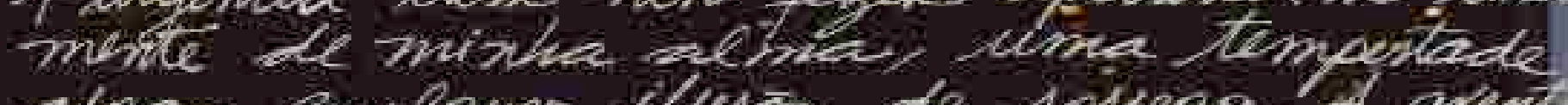

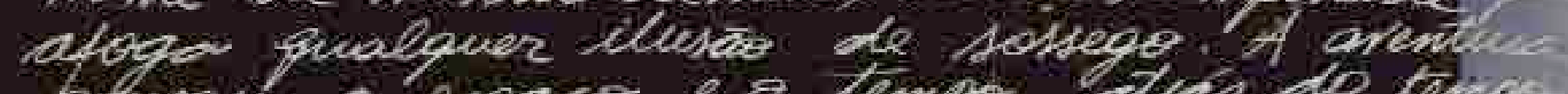

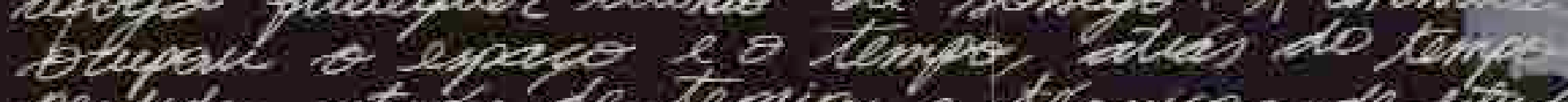

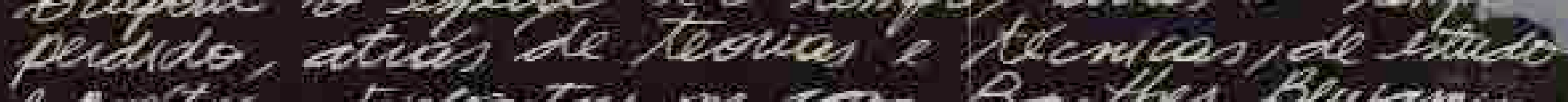

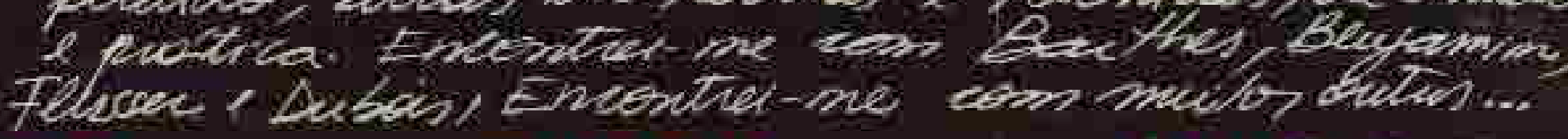

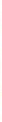


multidões, trânsitos e edifícios. O panorama urbano, traçado por uma infinidade de vistas e por um olhar fortuito, compreende uma cidade em movimento contínuo 7 .

Schapiro acredita que o século XIX presenciou uma mudança na visão que implica o reconhecimento da percepção singular do indivíduo ${ }^{8}$. O autor pondera sobre o crescimento avassalador das cidades, lado a lado ao aparecimento, em certas obras de arte, especialmente as pictóricas, de movimentos rítmicos, vastos e variados, sem um centro definido, e ao surgimento do tráfego casual e de uma tendência à dispersão de certos elementos ${ }^{9}$.

O que nos interessa nesse momento (e que pode ser observado em Camille Pissarro, assim como em Monet e tantos outros pintores dessa época) é o fato de que o lugar do observador nada tem de privilegiado, mas, ao contrário, é apenas um dos muitos pontos possíveis de onde se pode divisar o interminável fluxo da vida na cidade: ele é um habitante da cidade ${ }^{10}$.

7 Meyer SCHAPIRO. Impressionismo: reflexões e percepções, p. 133.

8 lbid., p. 160.

9 Ver, por exemplo, de Clamille Pissaro, "Place du Théâtre Français", 1898, óleo sobre tela, 72x93cm, Los Angeles County Museum of Art.

10 lbid., p. 162.

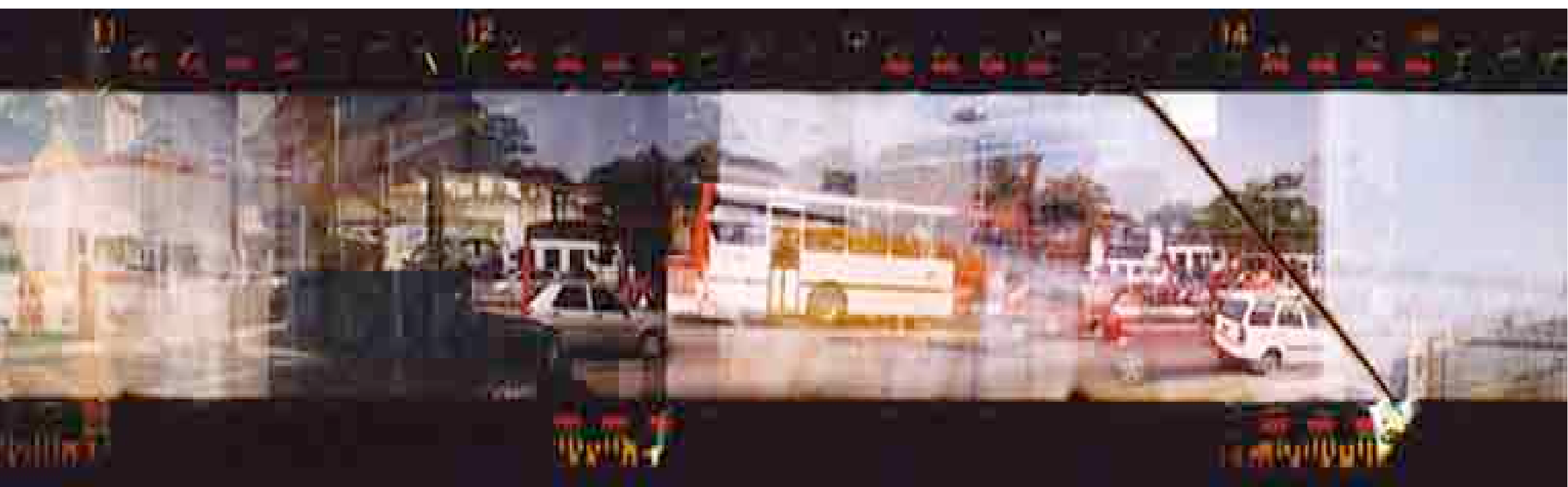


própria existência (conforme nos é possível observar pelas ações coletivas da revolução na França entre 1789 e 1871) como uma força ativa na formação da história (justamente em contraste com a idéia de uma massa passiva, de um povo sujeitado ao Estado, à Igreja, ao local de trabalho, ao lar) capaz de conferir à cidade um novo papel como espaço histórico. 0 período de 1840 a 1880, para Schapiro, é justamente a época em que o "público-multidão" descobriu-se como força social e política, como poder econômico, e também esse é o momento da origem de novas formas de sociabilidade e de discursos urbanos, em que se reformulam as maneiras e relações pessoais ${ }^{12}$.

Em Paris, a rua e, em especial, os bulevares eram as áreas comuns do parisiense, a sua vista mais prezada. Com relação a isso Schapiro levanta uma discussão sobre a preeminência do olho como meio de experienciar a cidade: "essa volúpia do olho, em suas formas parisienses especiais, foi uma condição (...) para o crescimento de uma sensibilidade pública próxima à dos impressionistas"13.

12 Meyer SCHAPIRO. impressionismo: reflexões e percepções, p. 164.

13 Ibid., p. 166.

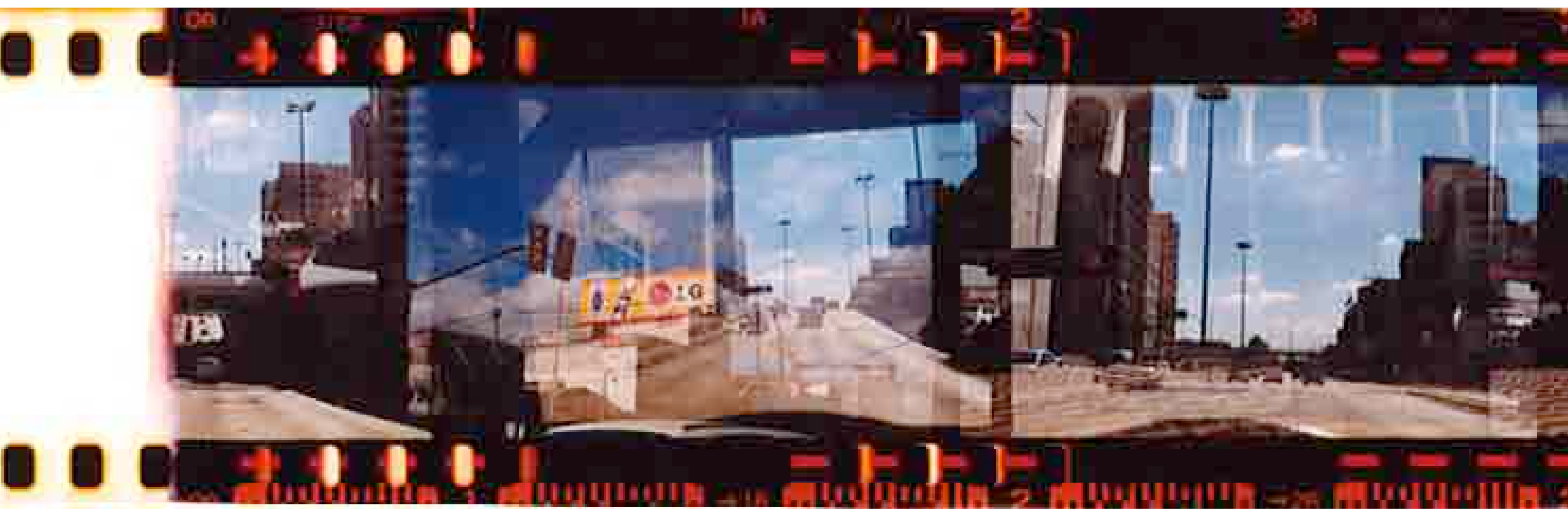


Schapiro não se refere somente a um fundamento do estilo de pintura, mas a uma cultura autônoma do olhar que se esboçava em Paris, um deleite cultivado pelo visual e uma abundância de novos meios inventados para a sua satisfação: "os impressionistas começaram a desenvolver a cultura coletiva parisiense da visão na complexidade maior das maneiras individuais de ver. As percepções pessoais foram exploradas em obras que alinhavam a visão do artista com a atividade diária e variada do cidadãoflâneur" 14 .

Com relação à fotografia, Schapiro afirma que ela, "com suas lentes, sua exposição rápida e a revelação controlada de uma chapa sensível à luz, oferece uma analogia técnica ao compromisso impressionista com a luminosidade e a representação direta de um objeto visível" 15.

Mas o que me interessa em relação à cidade e ao dispositivo fotográfico são as qualidades compartilhadas entre ambos, desde os impressionistas; ou seja: a idéia de experimentar a luz ou de experimentar por meio da luz; a confrontação direta experiência/ matéria/ luz; a rapidez do processo de

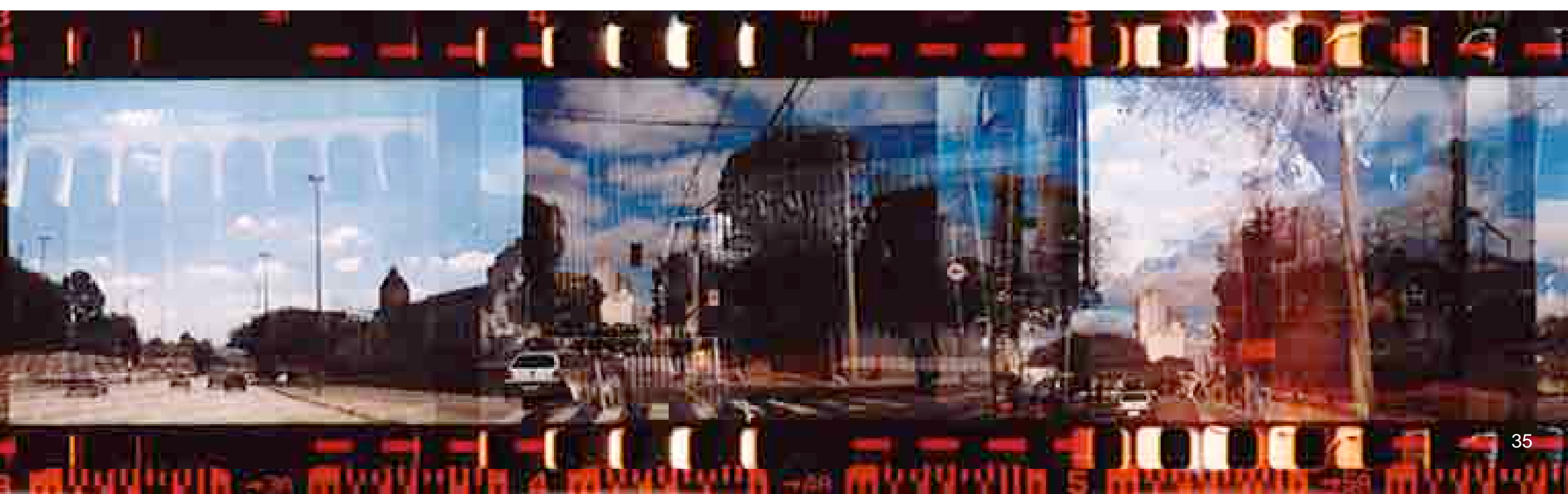


exposição/ registro fotográfico e a "foto-visão" cotidiana das coisas, com tudo o que isso implica de momentâneo e informal ${ }^{16}$.

Nesse sentido, buscamos o pensamento de um outro autor, Argan, que contesta a objetividade fotográfica, afirmando a parcialidade das escolhas do fotógrafo desde as suas características subjetivas - gosto, preferências, cultura - até as suas inclinações estéticas manifestas nos estilos de época.

A fotografia, como recurso ou instrumento técnico, tem especificidades que me atraem: ela permite ver um grande número de coisas que escapam à percepção visual corriqueira, tornando visíveis inúmeras coisas que meu olho orgânico, mais lento e menos preciso, não consegue captar. Além disso, traz à tona as realidades do muito pequeno e do demasiadamente grande (reveladas pelas lentes macro e teleobjetivas) ${ }^{17}$.

Walter Benjamim, sob um outro ponto de vista com relação à técnica, abordará os sentidos implicados na reprodução da obra de arte, para a qual a fotografia e o cinema teriam, segundo ele, um papel fundamental.

16 Meyer SCHAPIRO. Impressionismo: reflexões e percepções, p. 184.

17 Ibid., p. 81.

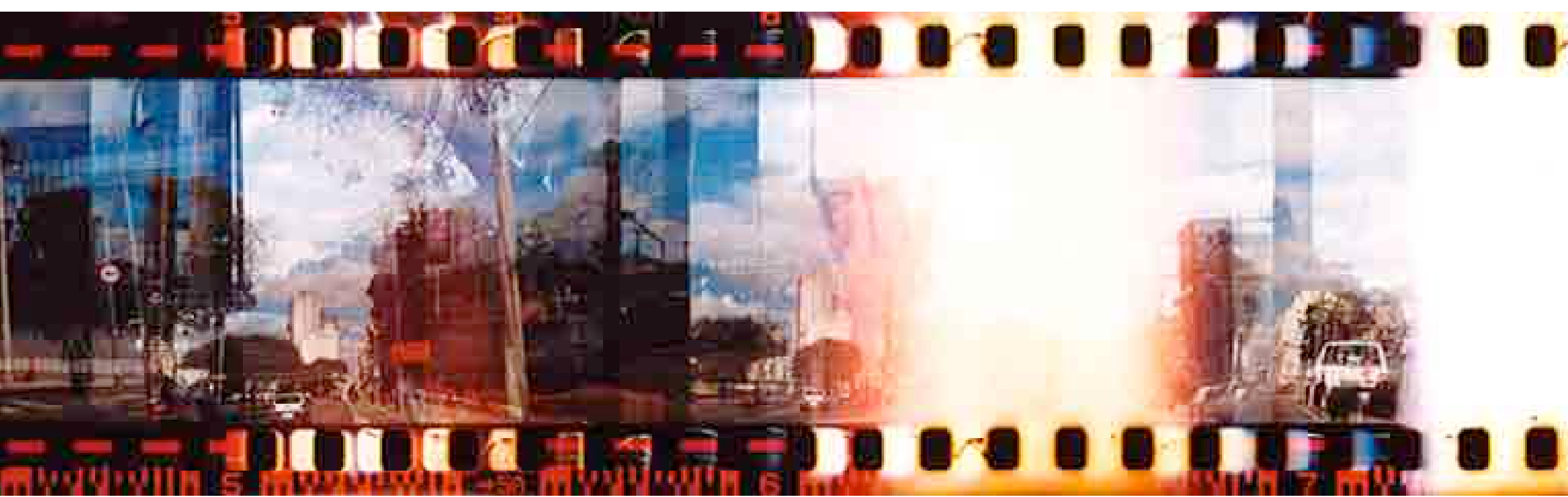


Para Benjamin, a obra de arte sempre foi suscetível de reprodução ${ }^{18}$, mas a diferença é que a sua época, seria marcada por um fenômeno inteiramente novo, as variadas técnicas de reprodução; com a gravura em madeira conseguia-se reproduzir o desenho; com a litografia, o processo de confiar o desenho à pedra era ainda muito mais fiel, mas com a fotografia, a mão liberou-se das tarefas artísticas de reprodução de imagens. Como o olho apreende as imagens muito mais rapidamente do que a mão desenha, a reprodução fotográfica das imagens pôde ser feita, a partir de então, num ritmo mais acelerado e capaz de acompanhar a cadência das palavras ${ }^{19}$.

Benjamin, nesse ponto, está preocupado com o assédio das novas técnicas de reprodução às formas de arte já constituídas anteriormente. Preocupa-se sobretudo, com o fato de se imporem, elas mesmas, como formas originais de arte. Aqui, Benjamin compreende a arte cinematográfica e a reprodução da obra de arte como os maiores reveladores desse assédio, afirmando logo em seguida que, à mais perfeita reprodução, faltará sempre a unicidade da presença da própria obra de arte, no local mesmo onde ela se encontra 20.

18 "Em todas as épocas discípulos copiaram obras de arte a título de exercício; mestres as reproduzi ram para assegurar-Ihes difusão; falsários as imitaram para assim obter um ganho material". Walter BENJAMIN. "A Obra de Arte na Época de sua Reprodutibilidade Técnica". In: LIMA, L. C. (org.). Teoria da Cultura de Massa, p. 210.

19 Walter BENJAMIN. "A Obra de Arte na Época de sua Reprodutibilidade Técnica”. In: LIMA, L. C. (org.). Teoria da Cultura de Massa, p. 211.

20 lbid., p. 212

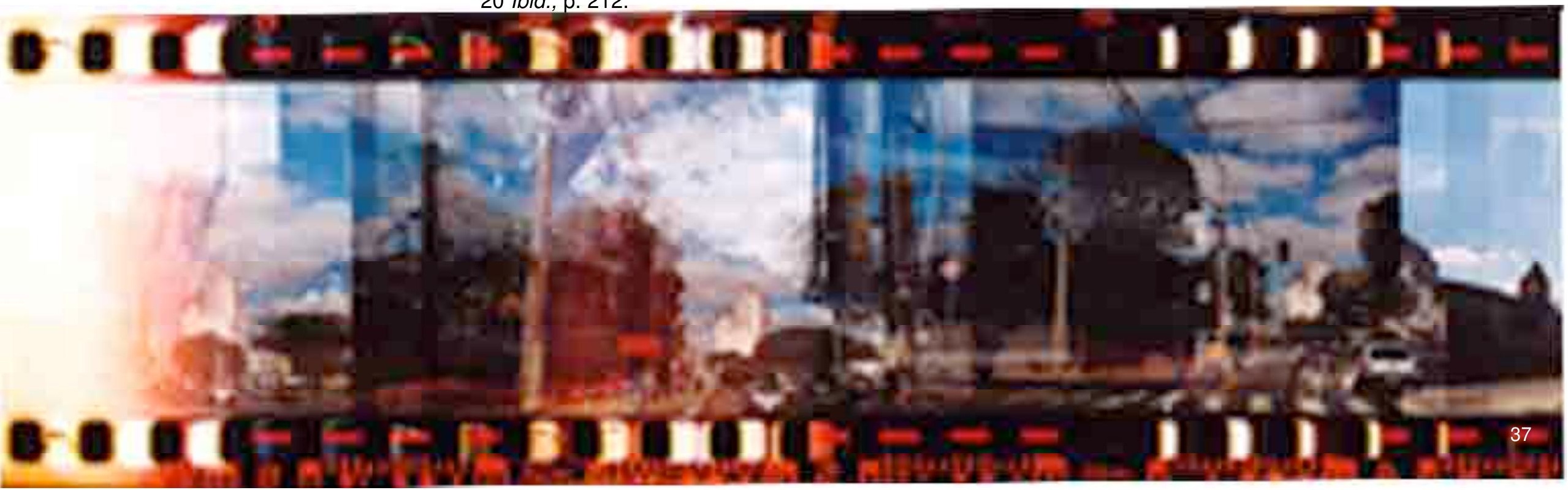


Por hora, não nos aprofundaremos demais nas proposições de Benjamin. Aludiremos apenas à importância de suas considerações no que diz respeito à idéia de reprodutibilidade da obra. Tais considerações, associadas a outros pensadores que a ele se referiram, formam um campo de discussão sobre a idéia de técnica e de tecnologia, que nos foi cara ao longo de toda pesquisa.

De qualquer forma, Benjamin afirma que, para se pensar uma obra de arte na era de sua reprodutibilidade técnica, seria preciso levar em consideração um grande conjunto de relações que culminariam em proposições como uma obra de arte emancipada da função ritualística e que poderia ser concebida justamente para ser reproduzida21.

Benjamin alerta para o fato de que, no caso do cinema, um estúdio de filmagem apresenta um conjunto de atividades que impõem ao olhar os mais diversos elementos estranhos à cena objetiva: máquinas e equipamentos de diferentes tipos e dimensões, instalações e artifícios cenográficos de grandes proporções. Para que o olho possa abstrair esses elementos, ele

21 Walter BENJAMIN. "A Obra de Arte na Época de sua Reprodutibilidade Técnica”. In: LIMA, L. C. (org.). Teoria da Cultura de Massa, p. 217.

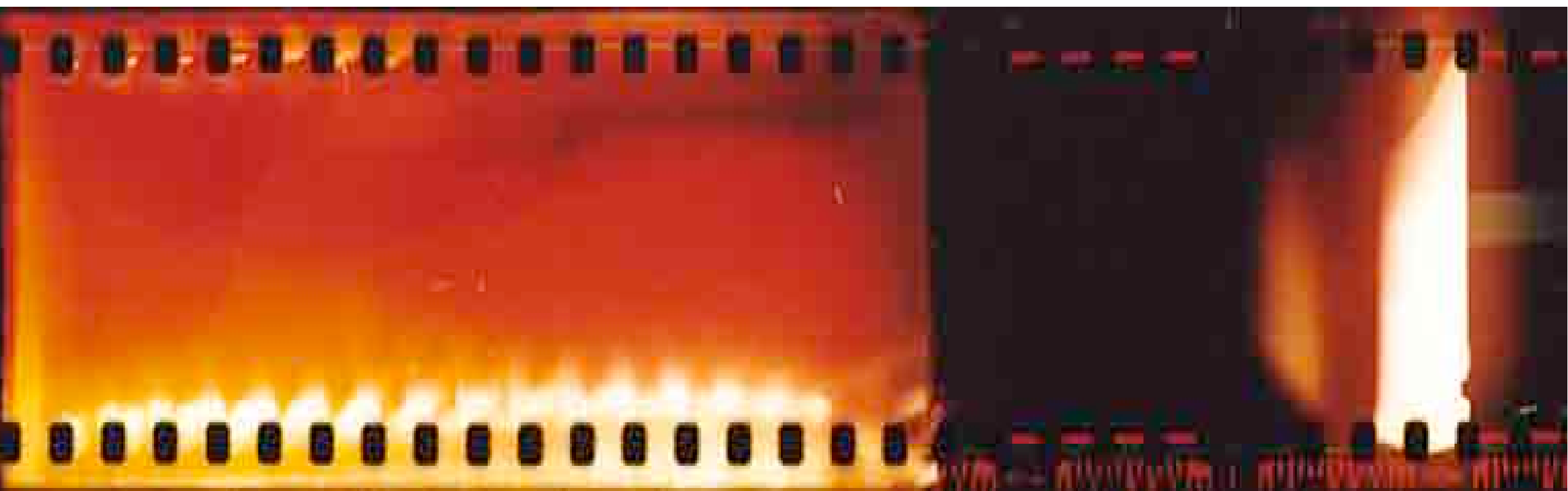


deve confundir-se com o visor da câmera. Por exemplo: para simular a realidade despojada e natural, seria preciso recorrer a procedimentos técnicos específicos nas tomadas de cenas, como a determinação de certos ângulos de visão da câmera que não permitissem a visualização dos fios, refletores e outros aparelhos complementares que lá estivessem. Da mesma forma, a seqüência cronológica do filme não corresponde à seqüência cronológica da filmagem. Assim, a montagem, o "método técnico" inventado pelo cinema, organiza as várias seqüências de imagens, realizadas independentemente umas das outras e confere, desse modo, ao filme todo uma determinada temporalidade. Então, a almejada realidade despojada ou natural na imagem é a mais artificial de todas. Aqui, Benjamin sentencia: "assim, no mundo da técnica, a captação imediata da realidade enquanto tal é agora uma simples quimera"22.

Não desconsiderando as proposições de Benjamin e de alguns de seus mais importantes seguidores e críticos (entre os quais poderíamos distinguir Adorno e Marcuse), Guattari entende as transformações técnicas e

22 Walter BENJAMIN. "A Obra de Arte na Época de sua Reprodutibilidade Técnica”. In: LIMA, L. C. (org.). Teoria da Cultura de Massa, p. 229.

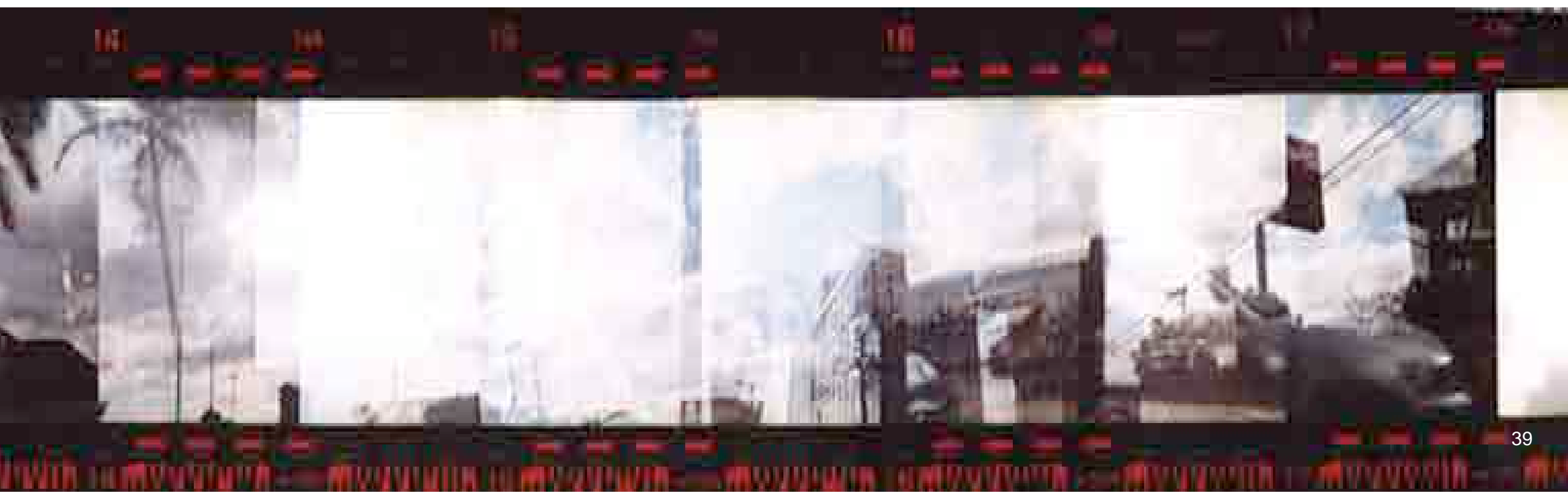


tecnológicas sob o ponto de vista de duas tendências contrárias uma a outra: uma inclinada à força de homogeneização, universalizante e reducionista da subjetividade, e outra propensa a um processo heterogenético e de singularização ${ }^{23}$, evitando qualquer ilusão progressista ou sistematicamente pessimista ${ }^{24}$. Ele encontra na Estética a possibilidade de um novo paradigma, para se pensar o problema da tecnologia e suas implicações relativas à produção cultural contemporânea e é justamente esse o solo em que está desenvolvida esta pesquisa: o paradigma estético processual.

Entendo, com esse trabalho, uma potência da cidade para o sentir, de tal maneira vigorosa, que parece impossível a alguma estrutura de senso comum ou de habito no terreno estético resistir às mudanças vertiginosas. Uma cidade modifica-se continuamente pelas técnicas e tecnologias de captura e edição de imagem na máquina, sou eu quem arquiteta um modo de ser ao mesmo tempo meu e dessa cidade: uma invasão acelerada de um no outro. Não há paisagem que permaneça intacta por muito tempo. O espaço ou os lugares são sempre de passagem. As pessoas a pé, de carro,

23 Félix GUATTARI. Caosmose Um novo Paradigma Estético, p. 15.

24 "A produção maquínica de subjetividade pode trabalhar tanto para o melhor quanto para o pior", afirma Guattari (Ibid., p. 15.).

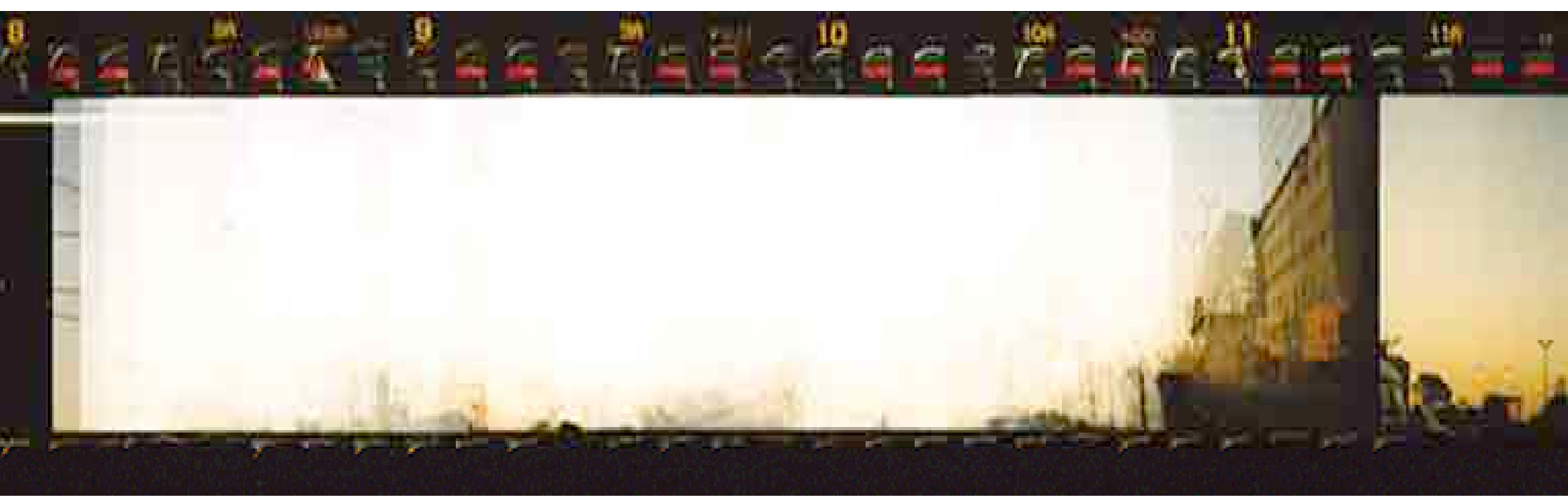


elementos que, em certo sentido, são insubordináveis, que vazam as formas e perturbam os processos de assujeitamento e organização da experiência na cidade.

Nesse sentido, a propensão que o computador tem para renovar as matérias expressivas da imagem e operar uma contaminação direta aos outros campos (que formam com ele um agenciamento, realçando e reavaliando as dimensões criativas que atravessam todos esses demais campos), tornou-o, juntamente com a máquina fotográfica, o instrumento preferencial para 0 desenvolvimento do trabalho. O meio eletrônico e as operações poéticas nele realizadas levaram ao ponto extremo a minha capacidade de invenção de coordenadas mutantes, de engendramento de qualidades de ser inéditas, jamais previstas, jamais imaginadas.

As máquinas empreendidas em além da cortina preta são como próteses que, aliadas ao meu organismo, permitem-me mais do que adentrar a cidade, pois me possibilitam viver os movimentos e transformações urbanas

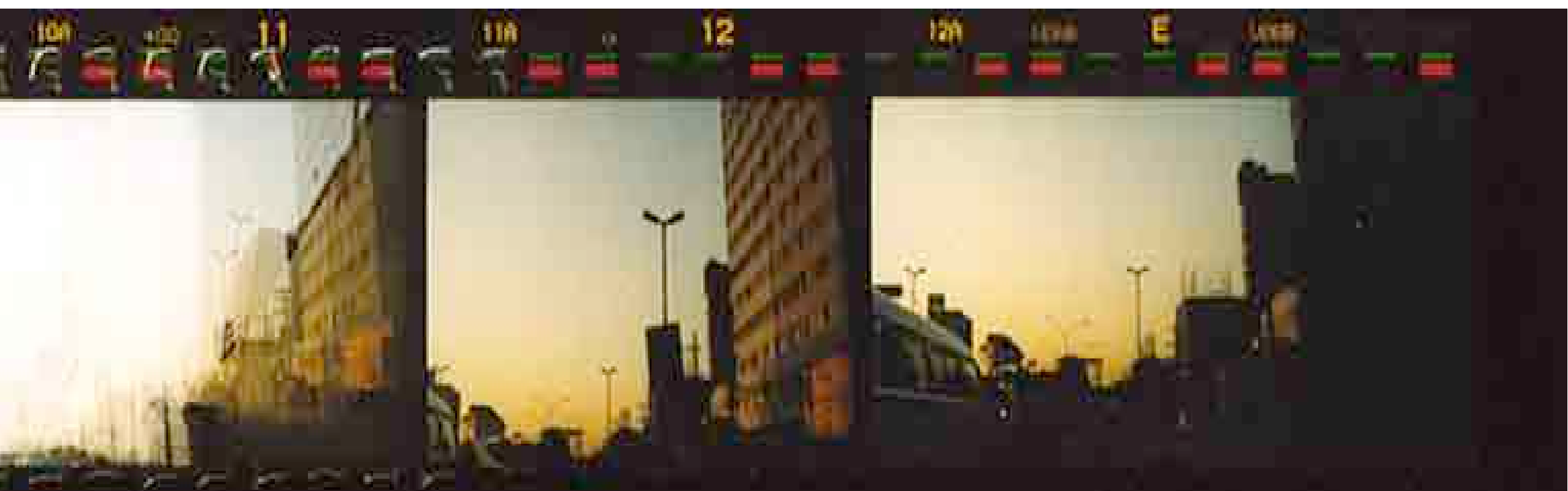


despida de uma visão puramente subjetiva e, além disso, ajuntam os tecnológicos aos aspectos biológicos, informáticos, sociais, teóricos e estéticos. Nesse momento, compreendo as máquinas em sua potência estética processual, e também em relação às possibilidades de outras tecnologias que podem vir ainda disparar. Em nossa época, a idéia de que nada acaba é uma realidade. Tudo é sempre um processamento 25.

Os procedimentos para a realização de além da cortina preta revelam-me um modo de existir e um modo de pensar, antes de qualquer coisa estéticos, que resultam na transversalidade de muitos territórios, é um modo de pensar por captura de imagens inventadas e é, portanto, ele mesmo, uma máquina de visão visionária, que se inventa não num momento privilegiado em que eu desacelero e medito, mas o tempo todo através das vivências banais que se transmutam em vivências fabuladas.

25 Guattari afirma, nesse sentido, que a ciência, a técnica, a filosofia, a conduta humana e a arte defrontam-se todas com resistências de materiais específicos, que elas fazem e articulam, nos limites dados, com a ajuda de códigos de ensinamentos históricos. Cada uma dessas atividades implica relações particulares entre modos finitos de seus materiais e os atributos infinitos dos Universos de Possível, dentre as quais destacamos aqui apenas a arte: nela, a finitude do material sensível torna-se o suporte de uma produção de afetos e de perceptos que tende a se distanciar dos quadros e coordenadas pré-estabelecidos. (Félix GUATTARI. Caosmose Um novo Paradigma Estético, p. 129) 
Se essa rua fosse minha Eu mandava, eu mandava muito bem Se a cidade fosse toda uma Se essa rua fosse sua Que é que tu mandava, nera nada mal Se a cidade fosse toda nossa sócarnaval

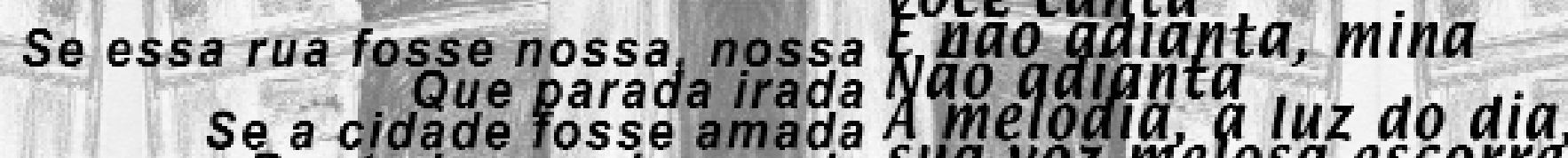
Por todo mundo e cada Por todo mundo e cada mina
Io vendo ngda mina

em entrada nem saida

nora e ma viga e malvada

sol so bate mesmo entre as grades va prisáo que e a cidade voce rima voce rala, você luta, Ece canta nao adianta, mina

vao gdianta volosa escorre sobre a minha, 
4. um modo de ser na cidade

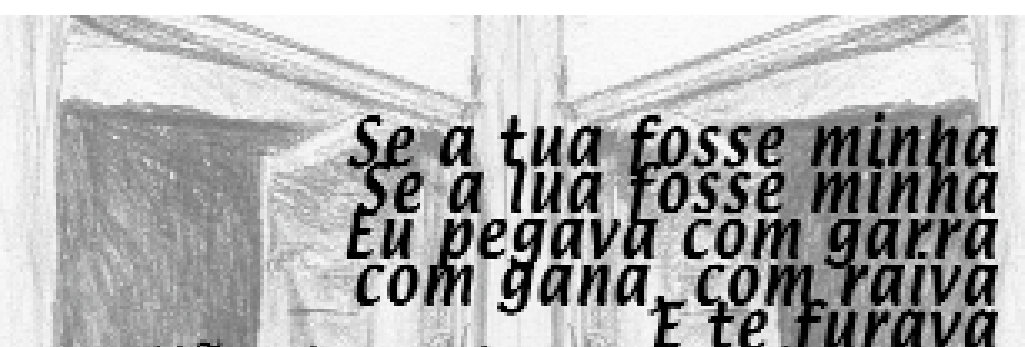

Não de matar, mas de viver eu te amava miña E a gente transformgva a cigdde em quase tudo aquilo que ela nao e a partir de duas pedras
Respeito e prazer prazer e respeito a partir de duas pedras
Respeito e prazer prazere respeito

que segura uma HK

e pro policial que não

sedeixa comprar

Eu rimo pro trabalhadore

bro assassino

Rimo pro menino aue

uinguem viu guem matou

Rimo pra $t$ i jra mim pro meu gmo

Que ainda nado ve saida nem entrada rimo minha rima aura e desesperada Rimo pra tudo mina...

Rimo pra nada

por isso eu rimo pro meu primo.

ESSA RUA

Rappin Houd = Luciand Mello - Cataduu Veluso/ Uns (Nalasha) 
Sergio Paulo Rouanet discute o "Trabalho das Passagens" do flâneur, numa reflexão em que se pergunta se é a cidade que habita os homens ou se são eles que moram nela ${ }^{27}$, problema primordial de além da cortina preta.

Afirma Rouanet que, ao mesmo tempo em que se sente em casa, na cidade, o flâneur aliena-se dela: mesmo tendo nascido ali, a cidade não é mais uma pátria; ela Ihe é tão imanente, que ele pode vê-la como se a visse de longe, estrangeira, "longe-temporal" que faz dela uma cidade antiga28.

Entrevejo o flâneur (obviamente que de um outro tempo e de uma outra cidade) na distância e aproximação justas que todo encontro pressupõe, como uma referência longínqua daquele que já há muito experimenta a cidade e quer descobri-la em um sentido, para além do lugar necessário para se estar ou viver. O interesse na figura do flâneur reside também no fato de que ele é capaz de realizar a percepção da cidade sem se descolar dela. A cidade que o flâneur vê de longe, para a qual ele olha sob um olhar antigo, atualiza-se em além da cortina preta sob a forma de uma cidade que não se pode ver e da qual se é parte. É uma cidade que não

26 Guimarães ROSA. Primeiras Estórias, p.

27 Sérgio Paulo ROUANET. "É a Cidade que Habita os Homens ou são eles que moram nela?"

"No meio do caminho tinha uma pedra 28 Ibid., p. 50. tinha uma pedra no meio do caminho tinha uma pedra no meio do caminho tinha uma pedra

Nunca me esquecerei desse acontecimento na vida de minhas retinas tão fatigadas Nunca me esquecerei que no meio do caminho tinha uma pedra tinha uma pedra no meio do caminho no meio do caminho tinha uma pedra" 
permite ser observada ou percebida sem que já se esteja misturado às suas velocidades e acelerações.

É através do "Trabalho das Passagens", como afirma Rouanet, que o flâneur de Baudelaire e Benjamin vai, pouco a pouco, mostrando a sua cidade, uma "Paris" que não é a dos arquitetos, engenheiros, cidadãos, prédios, feiras, serviços, simples entidade topográfica, mas a de Balzac, a de sonho, dos mistérios noturnos, sensível a todas as vertigens.

A cidade que compreendo também não é a dos arquitetos ou essa entidade topográfica acima referida, porém tampouco é uma cidade reconstituída subjetivamente. Ao contrário, eu apenas ganho existência quando dissolvida na cidade, e são as imagens da cidade, como uma espécie de especularismo, que me constituem de fora para dentro - processo que é paradoxal, porque se trata de um esvaziamento que preenche, de um acúmulo que apaga.

Assim como no trabalho do flâneur, também em além da cortina preta existem encruzilhadas nas quais sinais fantasmagóricos cintilam por meio do tráfego 29 . Inscrevem-se na ordem do dia, acontecimentos incompossíveis entrecruzados de classes diversas, que se mesclam e tornam-se inalienáveis. A cidade me contrai, e eu a ela, em nossa rota diária.

29 Sérgio Paulo ROUANET. "É a Cidade que Habita os Homens ou são eles que moram nela?" p. 51

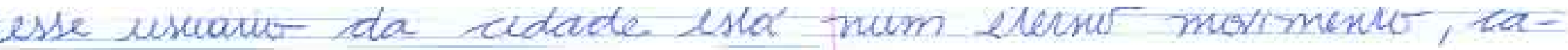
da vey mais uapido: de dentur do zars of muote láfona vîa $x$ poste se funde rom onit, a calcada ista na jamela A veloudade provora um

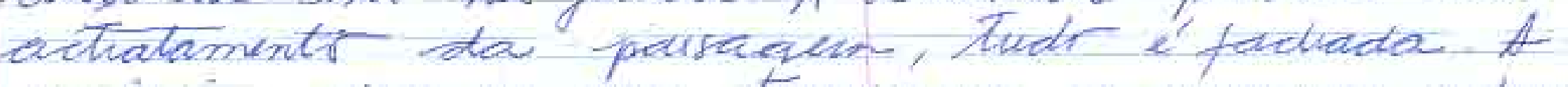

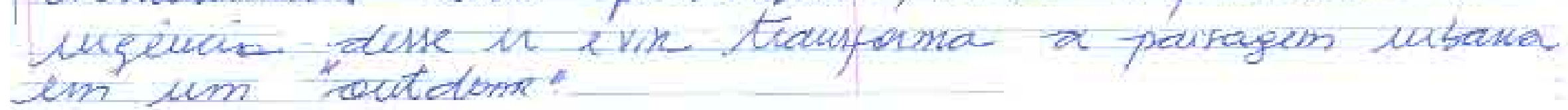



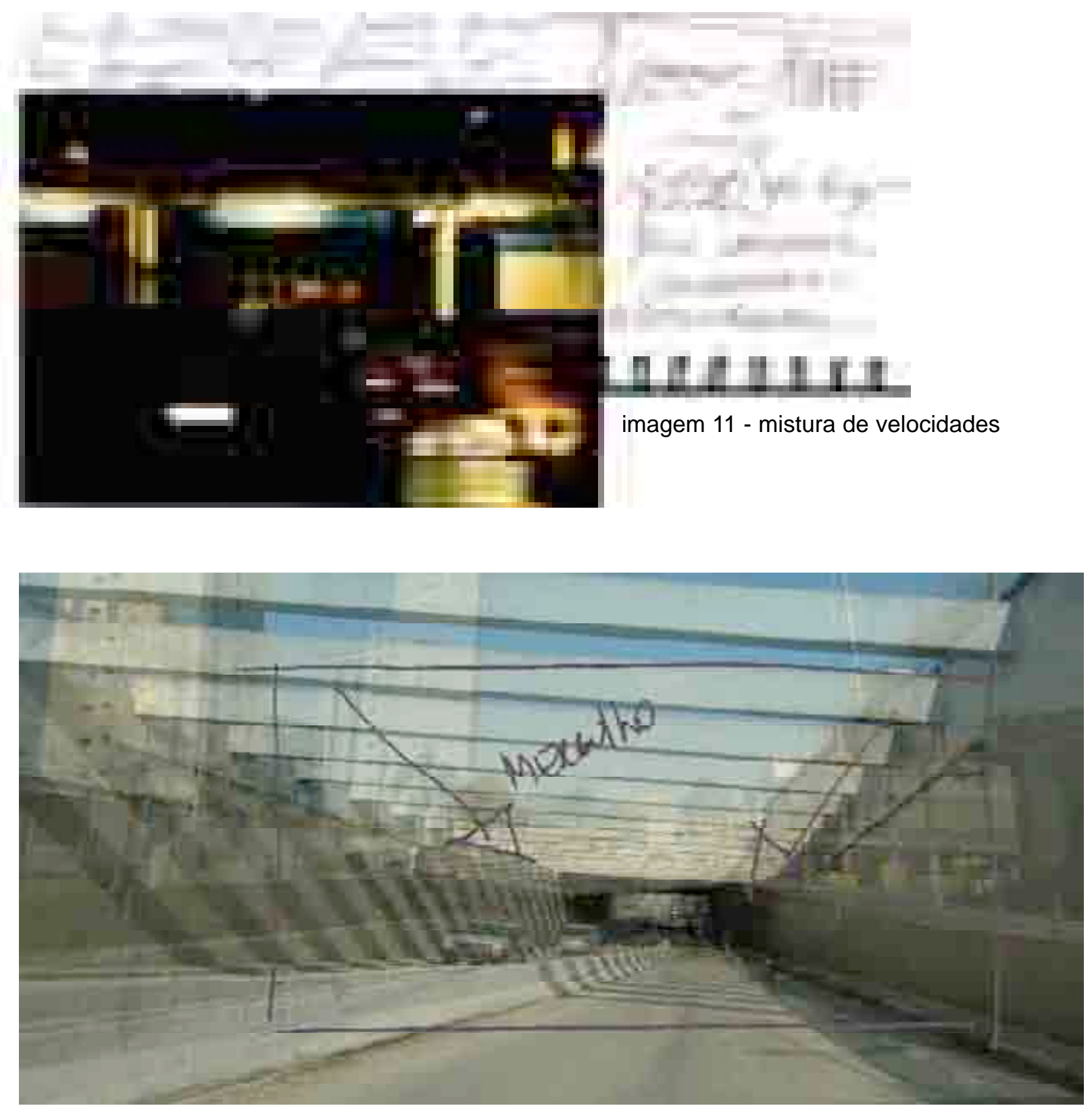

imagem 12 - exercício de imersão

"As coisas que eu sei de mim - são pivetes da cidade Pedem, insistem e eu me sinto pouco à vontade Fechada dentro de um táxi - Numa transversal do tempo Acho que o amor é a ausência de engarrafamento As coisas que eu sei de mim-tentam vencer a distância - E é como se aguardassem feridas - Numa ambulancia As pobres coisas que eu sei - Podem morrer, mas espero Como se houvesse um sinal - Sem sair do amarelo"

Transversal do Tempo - Elis Regina/ Composição: João Bosco/Aldir Blanc 
Diferentemente do flâneur, cuja reflexão sobre a cidade ocorre ao observála com certo distanciamento, é sobre imagens colhidas-fabuladas, em que se atualizam as referências concretas de um eu feito cidade, que reflito e penso. Isso me leva a especular sobre a experiência de ser num aqui/ agora e o tempo todo, mesmo e, principalmente, quando o eu está ausente porém completo - além da cortina preta. O flâneur/ Vera pousa, desce da sua condição aérea e mergulha na realidade líquida da cidade.

O essencial do "Trabalho das Passagens", segundo Rouanet, é que o homem habita uma cidade real e é habitado por uma cidade de sonho: nada mais material que a rua, mas sobre a materialidade do asfalto, surge o sonho do labirinto, que contém o desejo de chegar, o impulso de alcançar o objetivo (e nesse sentido é utopia), e o perigo de transviar-se, o risco de não chegar ao fim (e nesse sentido é mito) ${ }^{30}$.

Tudo isso, afirma Rouanet, numa cidade - Paris - que se configura como uma cidade de espelhos, espelhos olhando espelhos, donde nasce o sonho utópico da cidade-espelho, transparente, em certo sentido a mesma cidade na qual nos encontramos e à qual nos percebemos misturados, sendo permeados por ela, como se também nós fôssemos mais uma superfície transparente a refletir e rebater as outras múltiplas imagens da cidade.

O processo de reflexão deste trabalho tem o objetivo de deixar transparecer

30 Sérgio Paulo ROUANET. "É a Cidade que Habita os Homens ou são eles que moram nela?” p. 67.

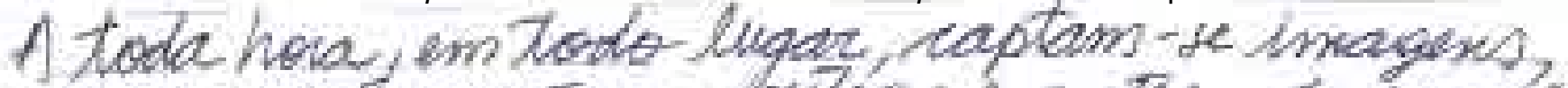

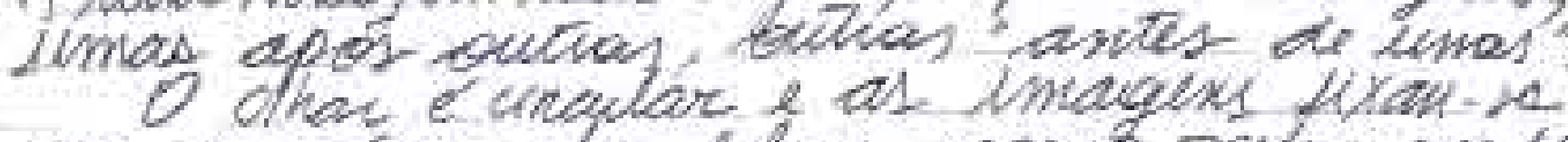

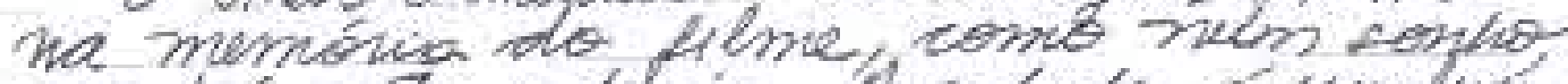

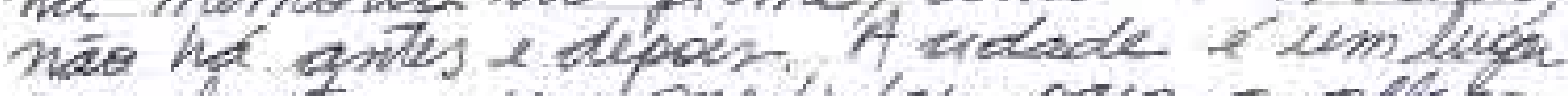

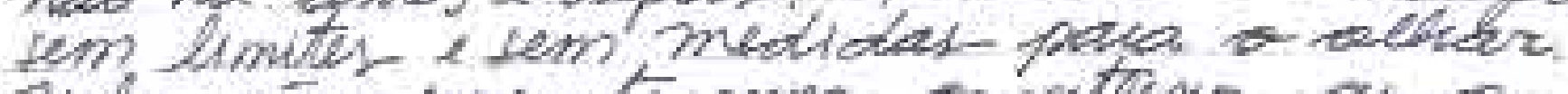

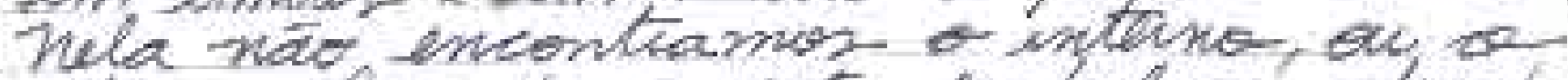

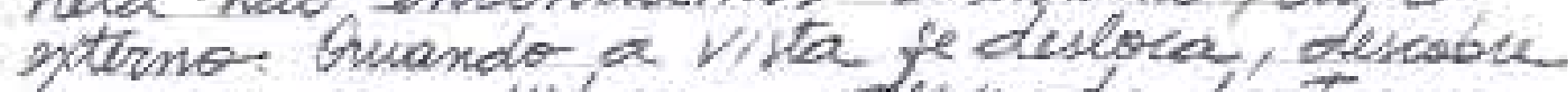

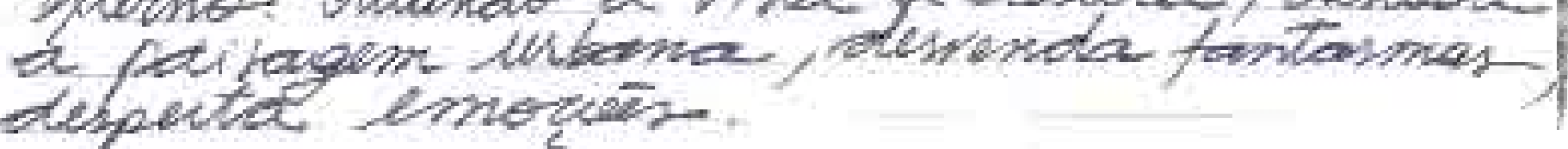


as operações de saturação e abarrotamento realizadas com a finalidade de conferir determinadas qualidades ficcionadas e gradientes intensivos às imagens capturadas. Aquilo que está sobreposto de modo transparente é pura opacidade: não há a placa que supõe um caminho a ser trilhado, e não há a faixa que convide a atravessar uma rua. Não há um caminho aberto a se adentrar e não há, enfim, materialidade no chão.

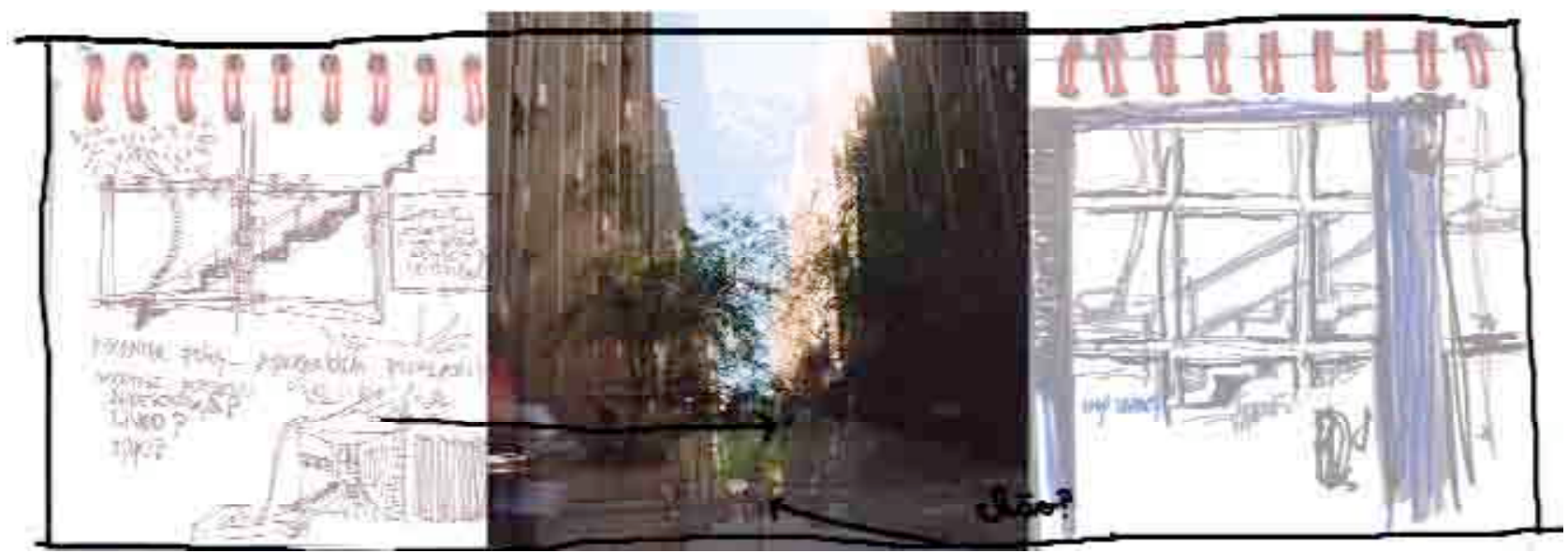

imagem 13 - desmaterialização do caminho

Os procedimentos poéticos são executados para ressaltar a derivação que ocorre no momento em que a fotografia é tirada no trânsito, no congestionamento, no túnel, enfim, em todas essas ocasiões de entrave, em que a sensação de que não há tempo e nem mesmo disposição infiltra-se por toda parte: o contorno, os limites, a resistência, a materialidade concreta; tudo atravessa qualquer coisa e é "atravessável". 


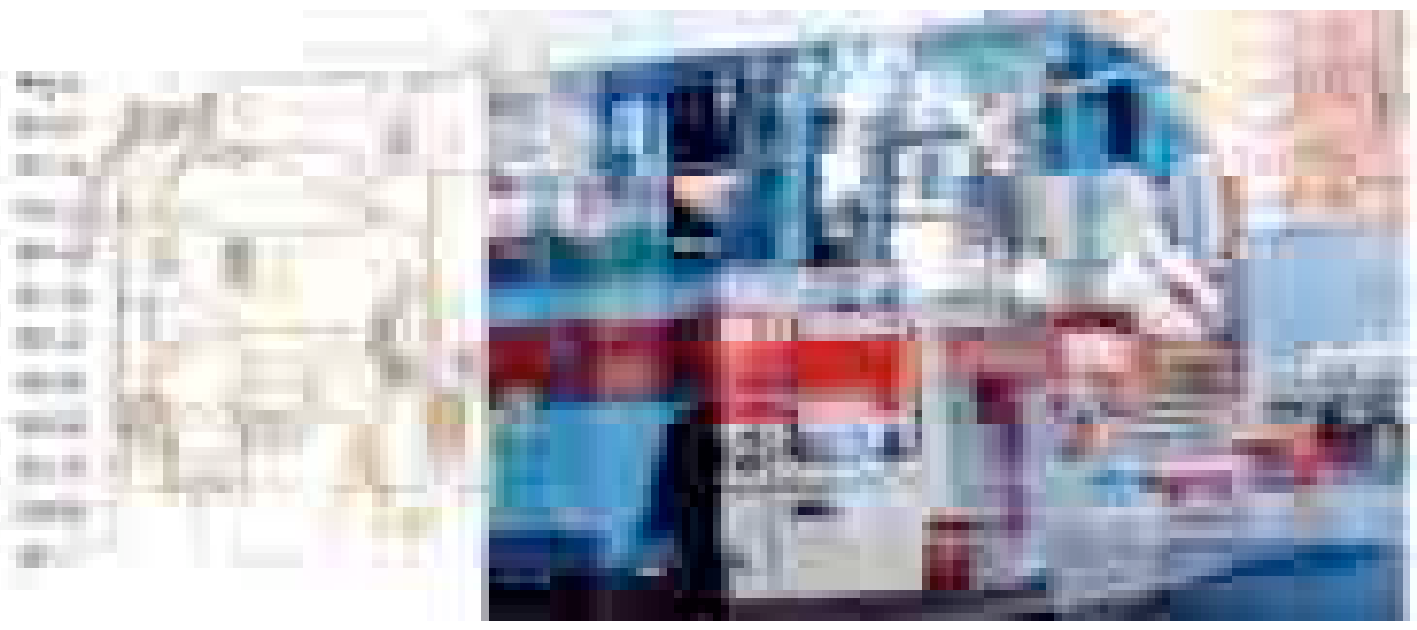

imagem 14 - "atravessável”

Percebo-me circulação desconhecida, ataque, invasão, incursões, viagens... Nunca é uma questão de reconhecimento ou de identificação mas, ao contrário, é um problema de vizinhança. Encontro-me agenciamento, dissolução, mistura, indiscernimento. Trata-se de pura circulação e ressonância: os edifícios em $\mathrm{mim}$ são verticalização e a terra horizontalidade; as coberturas e as grades são em mim estriamento, e as placas, sinais e slogans, deslocamentos - uma cidade divergindo de si própria. Sou, antes de ser, um devir-cidade.

Não é mera casualidade que as imagens capturadas tragam sempre elementos emblemáticos de trânsito - ônibus, automóveis, postes e

SAR. Pavto es una metropote Policentrico, megametrópote, cidate-mosáico de multiplas referencias cultrair, escoss e religiosas. Lugar de imigrantes: pordugueses e dtemaés japoneses e correanes ardas Juateus, glegos a romanos (italianos). comunhas de afficonos, índios a nordestinos - uger de brasiteiro. Sad Paulo de inumeras crencuar, retallio de paixoén, misériva ebeleza

sevá que far Paulo impies uma "ditadura no morimsuto-"

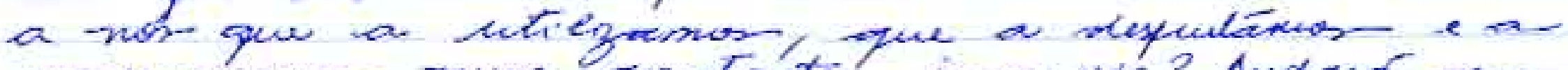
ronsuminos num ronstaute in-e-rik? Andand a 
edifícios, túneis, faixas de pedestre, placas de trânsito - porque estes componentes são espécies de "visualidades médias" de qualquer canto de cidade, de qualquer paisagem urbana. Sua existência decorre do agenciamento "passagem" e da vista de relance.

Se me reconheço nesse contexto, é somente como imagem, entrando desmaterializada na cidade, reflexo e espelho simultaneamente, pura superfície que reflete e contrai ao mesmo tempo, membrana que permeia e é permeada por tudo, numa dimensão temporal selvagem, não-domesticada.

Nesse sentido, a imagem não diz respeito a uma ou outra representação de endereço que tenha sido visto ou visitado. É relativa a uma experiência colhida pela impressão luminosa, na película fotossensível, de um espaço sempre flutuante, de superfícies não definitivas.

Parece haver uma iconografia da cidade, insinuada em meio às vistas mais ou menos turbulentas, em que estão presentes os caminhos e os indícios de passagem do homem pela cidade.

Mas, tanto nesse plano iconográfico quanto num plano indicial ${ }^{31}$, as referências à realidade concreta da cidade são abandonadas durante o processo de execução dos trabalhos: de um lado, a sobreposição das

31 Registrar e fixar no tempo são processos que, na fotografia analógica, envolvem a materialidade do traço ou do o vestígio de uma impressão. Para Rosalind Krauss, a fotografia "revela esta influência a ponto de lhe atribuir valor de sintoma ou índice, ao estilo da solução química que, por redução dos sais de prata expostos à luz em prata metálica, torna-se visível, na etapa da revelação, a imagem latente impressa sobre a placa ou película no fundo da caixa escura e a revela pelo que é: um índice no sentido atribuído pelo filosofo americano Charles S. Pierce, um signo que mantém, com seu referente uma relação direta, física, de derivação, de causalidade." (Rosalind KRAUSS, O Fotográfico, p. 9).

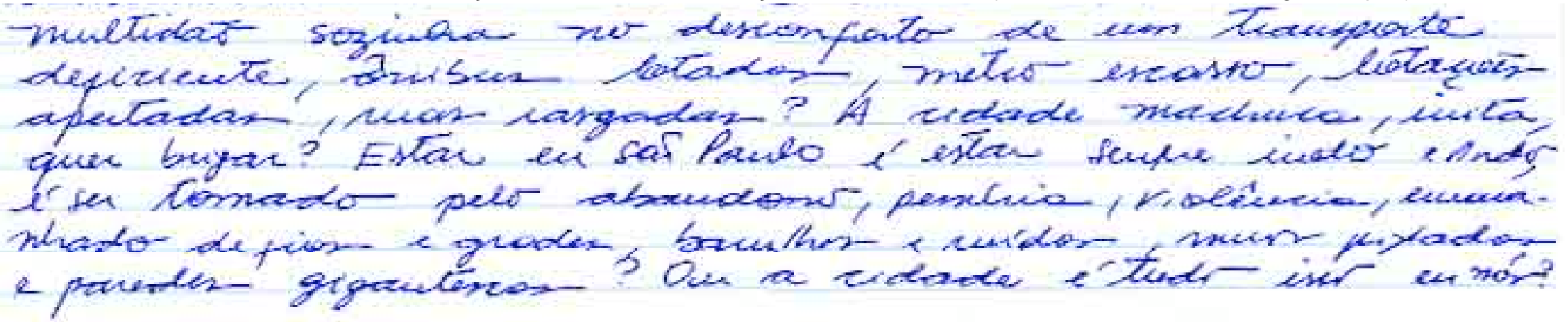


imagens e as interpenetrações que ocorrem já no próprio negativo, não servem como índice de qualquer endereço exato da cidade; de outro lado, os contínuos processos de captura e re-captura da imagem, sobretudo aqueles que envolvem a transcodificação de negativo material para imagem digital, vão pouco a pouco dissolvendo a questão da originalidade e substituindo-a pela do simulacro. Entretanto, só se pode colocar isso numa concepção de simulacro que o compreende como a emancipação da cópia, a cópia que não tem mais original: o índice da luz que iluminava os locais que foram fotografados já não existe mais, talvez nunca tenha existido.

Ainda que a originalidade indicial não seja uma questão aqui, haveria uma espécie de "indicialidade" na imagem, que poderia ser alegada: mesmo que reprodutível, um retrato fotográfico que apresenta o irmão de Napoleão, por exemplo, poderia sentenciar que vemos os olhos que viram Napoleão ${ }^{32}$.

Entretanto em minhas imagens não há um olho, mas vários, e também "cegueiras" (imagens que eu não vi e que foram apenas vistas pelo olho mecânico ou eletrônico das máquinas), "vesguices" (cruzamentos de olhares distintos, ou olhos olhando um para cada lado), o que significa dizer que, dificilmente, alguém poderá afirmar, em além da cortina preta que "viu o olho 
que viu este ou aquele canto da cidade". Não há vestígios concretos, só sensações: passageiras, efêmeras, híbridas; as imagens não possuem caráter documental para formar uma "memória de visão". Mas, na máquina fotográfica que captura essas imagens da cidade, por meio de um procedimento de composição e recomposição vertiginosa, o olhar desvenda uma imaginação coletiva.

O método dessas experimentações é a tradução dos diversos conteúdos captados, digitais e analógicos, por diferentes dispositivos maquínicos, em uma única "linguagem/ meio expressivo" - a eletrônica. Primeiro, tudo é passado para o computador e, depois, para os equipamentos de impressão digital.

Há algo da cidade que, já de início, está flagrado no trabalho. É um certo modo de ser por impulso ou movimento, e uma espécie de agenciamento improvisado de dimensões temporais, espaciais e corporais distintas que desagrega toda organização e suspende qualquer planejamento. A dissolução da forma concorre para a sensação de fluidez, de liquidez: as coisas bóiam, flutuam, passam a existir num sistema de circulação sígnica. Correntes distintas de tempo desacomodam as imagens e, a partir daí, no 

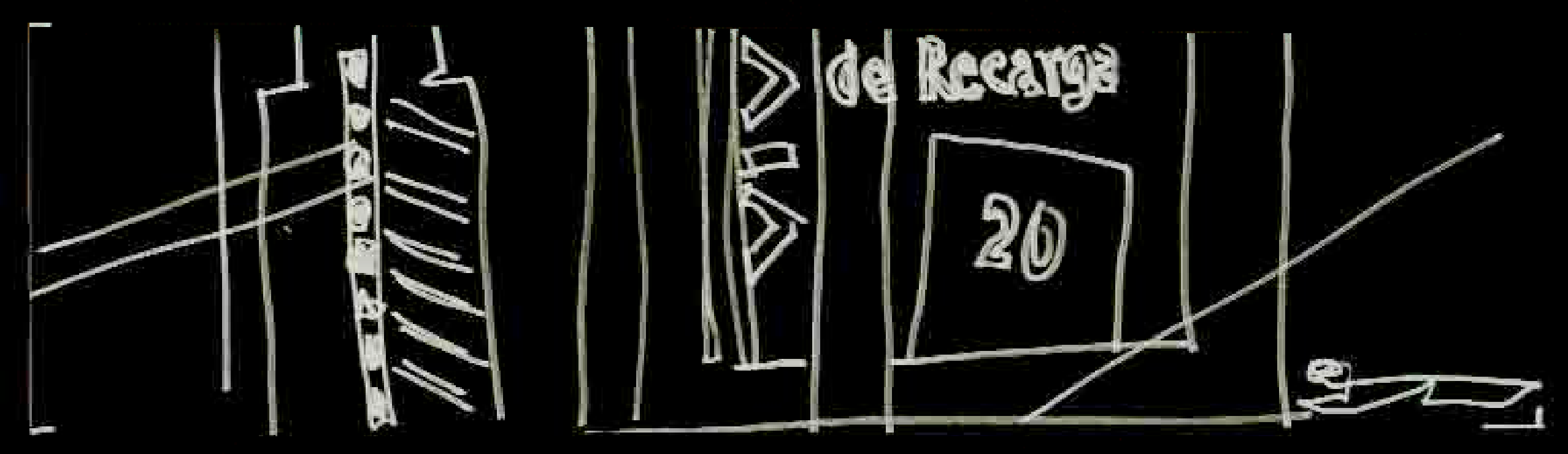
5. um tema possível

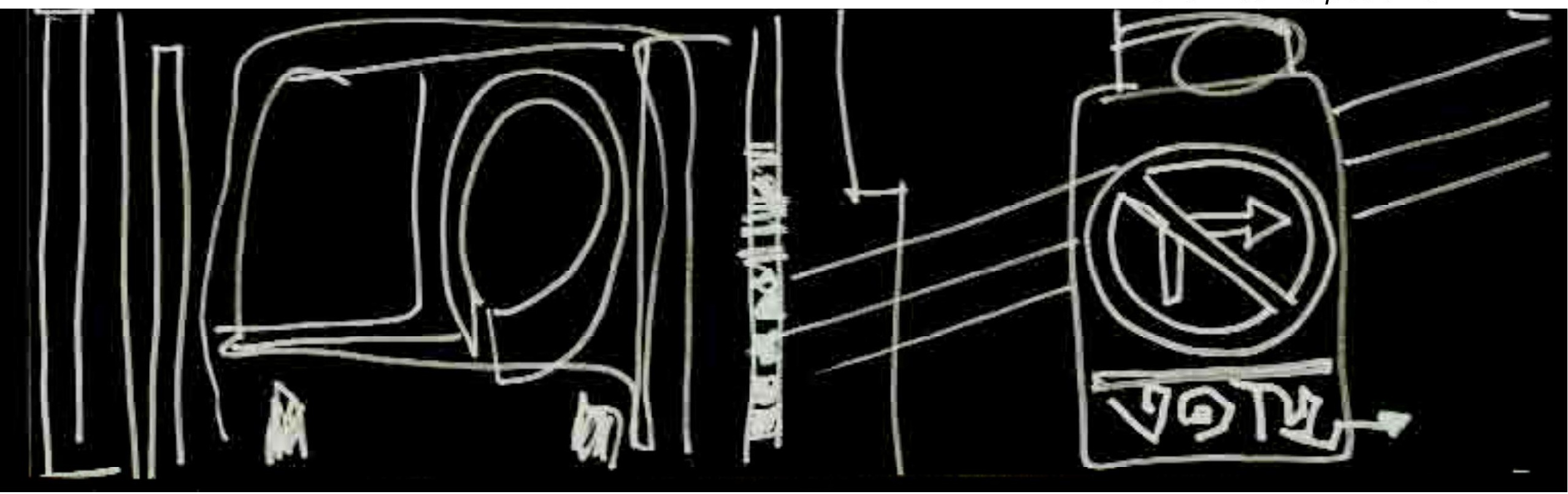


"sigo o anuncio e vejo em forma de desejo o sabonete em forma de sorvete acordo e durmo na televisão creme dental, saúde, vivo num sorriso o paraísoq uase que jogado, impulsionado no comercial (...) E na rua sou mais um cosmonauta patrocinador - Chego atrasado, perco o meu amor - Mais um anuncio sensacional" - Elis Regina - Comunicação (Edson Alencar/ Hélio Matheus) 
...ela não faz todo o dia tudo sempre igual, mas certamente quero que você venha comigo...

"O chão que não se pisa", "o solo que é flutuante", "a escrita no céu", "a nuvem na janela". Sensações de imagens e imagens de sensações. Vagar pela cidade dentro dos percursos já mais ou menos definidos. "Olhar por olhar", "olhar de sobrevôo", "olhar de submersão", exercício constante de ver e não ver. A cidade, em sua visualidade, tem uma maneira de se expressar, ela mesma, por navegação.

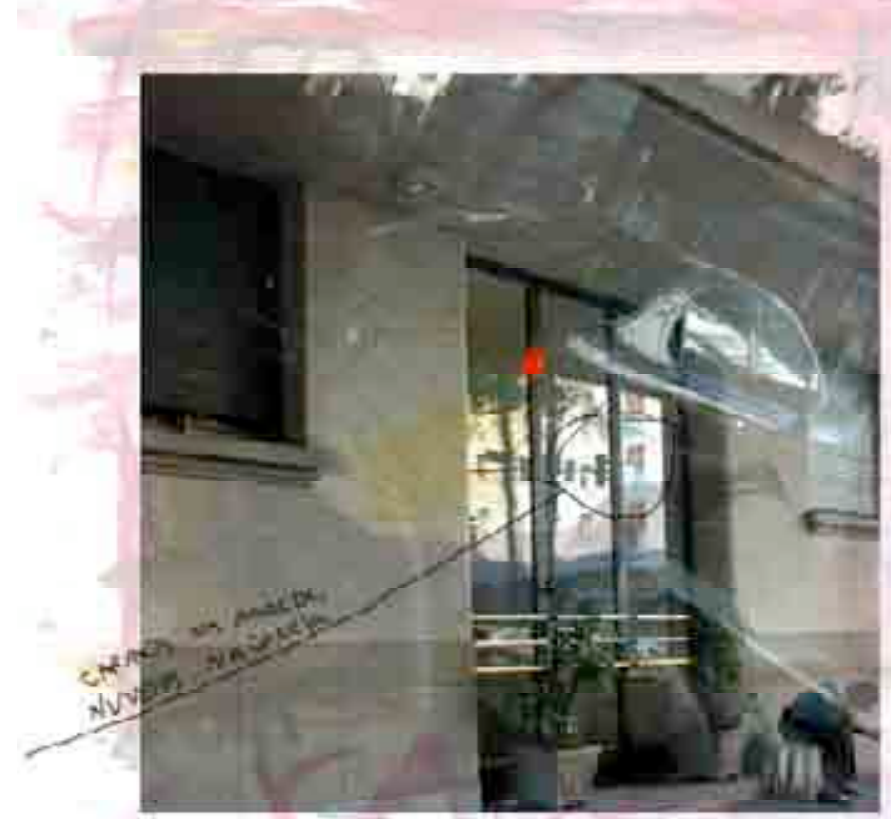

imagem 16 - flutuações verticais

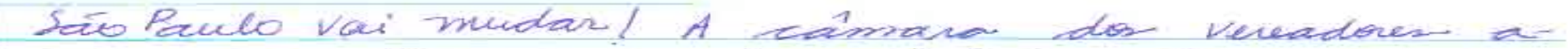

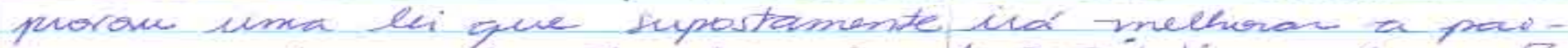

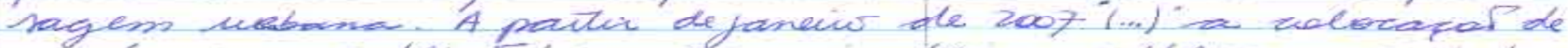

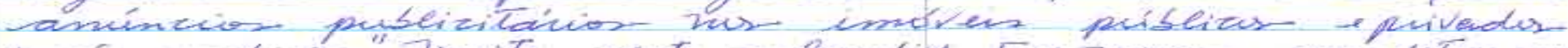

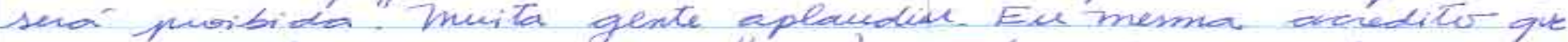

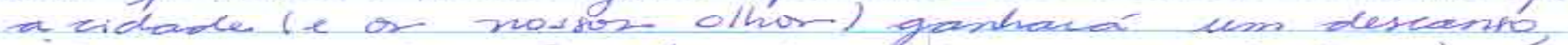

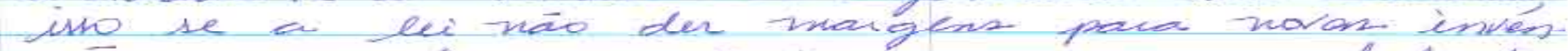

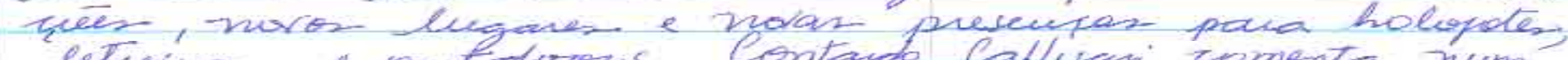

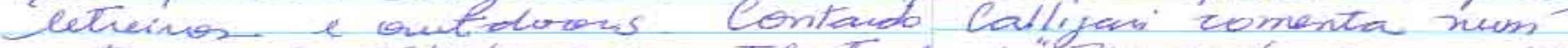

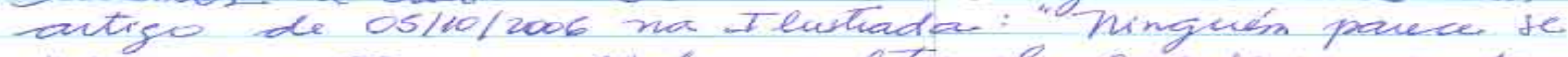

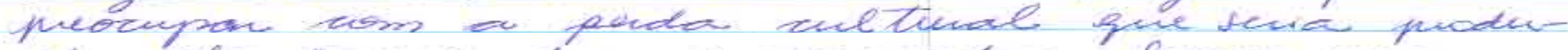

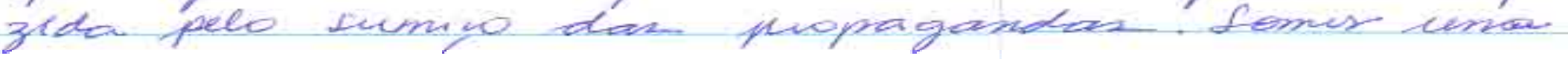


Estou quase sempre em movimento, e uma vez que tudo aquilo que vejo aparece e desaparece nas fugas de cada esquina, então não existo, estou sempre existindo ou sempre em vias de diferir de mim mesma nas dobras das ruas.

Não há unidade, mas apenas superfícies sem fundo somadas; tal é o chão que não se pisa, o prédio que não impede a passagem de luz, a escrita no céu, o carro que atravessa o outro.
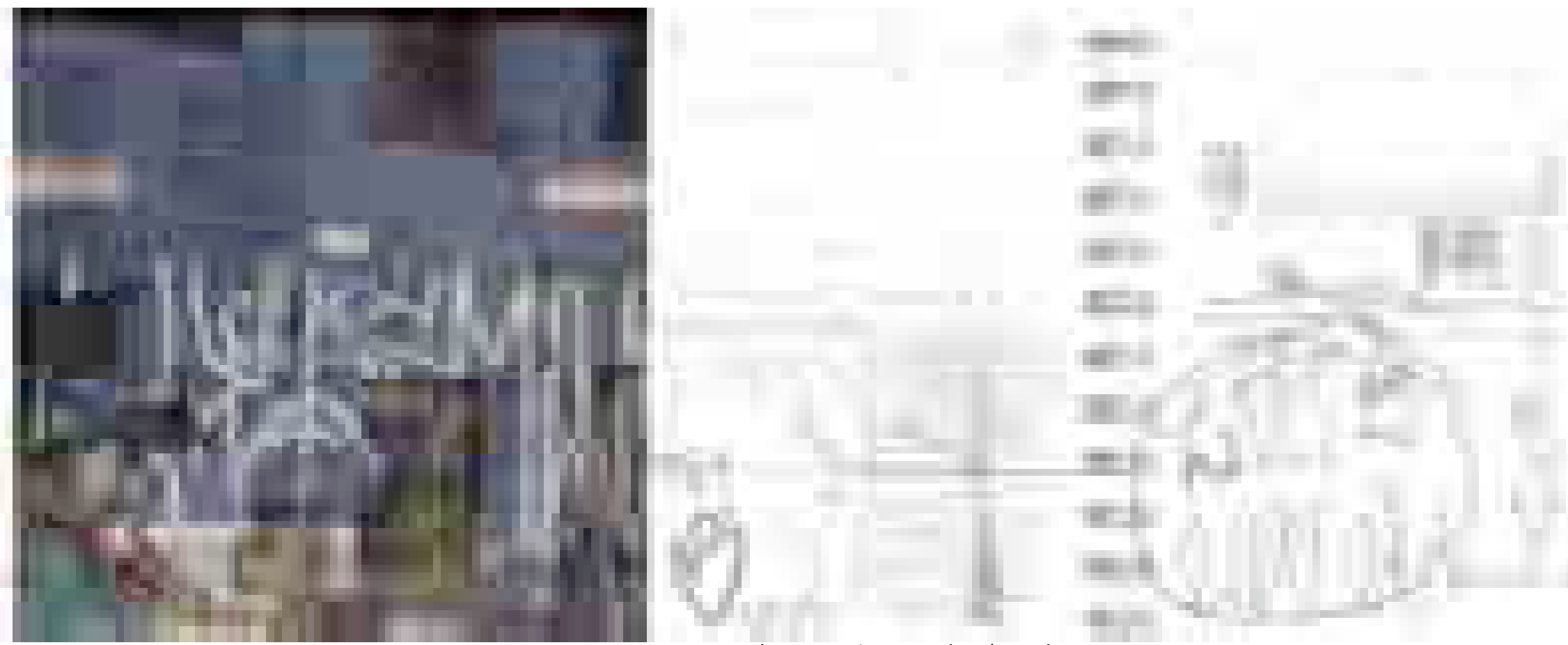

imagem 17 - escritas/ escrituras

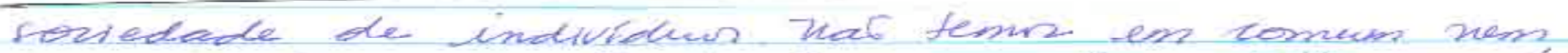

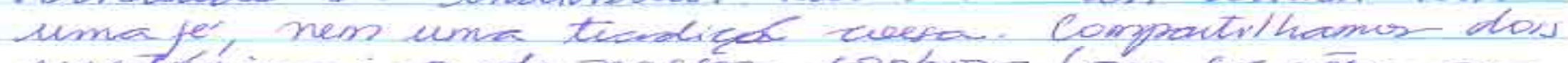

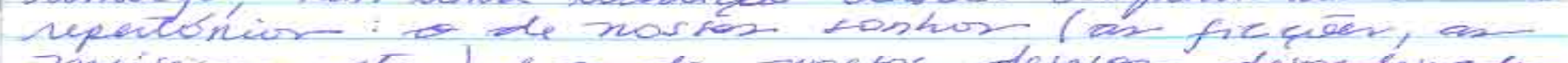

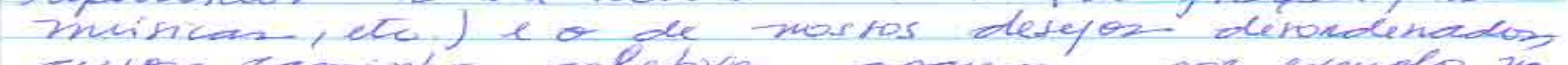

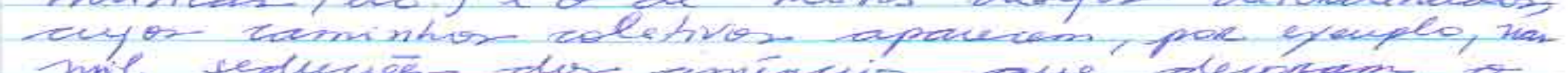

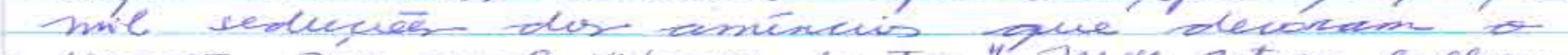

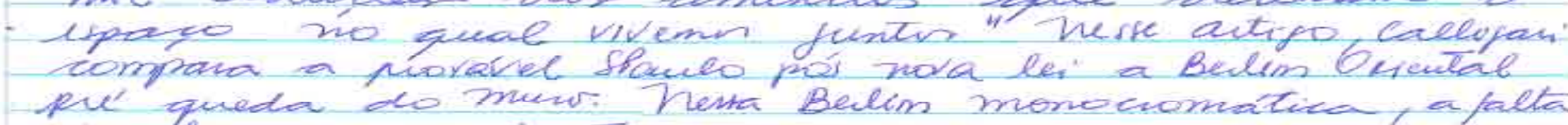

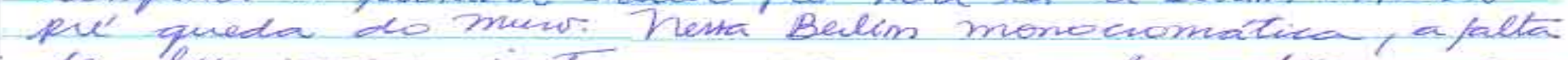

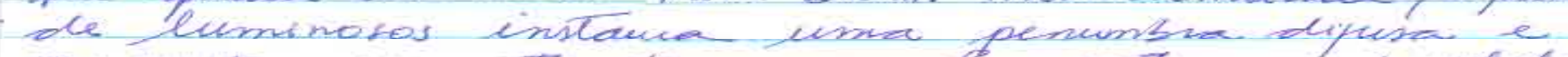

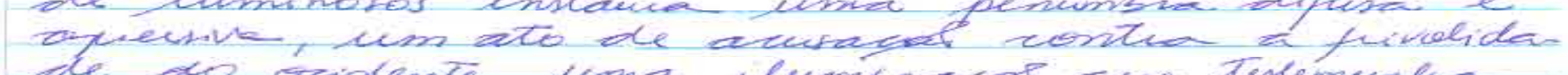

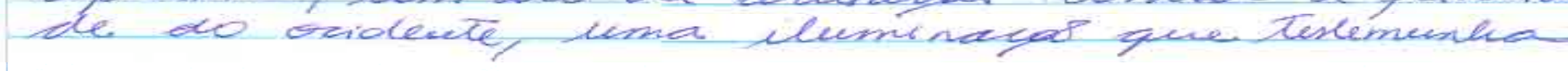


É sempre a mesma pergunta: qual visualidade mistura tantas e tão distintas perspectivas visuais, que não a da cidade? Como colocar tantas e tão diferentes imagens em uma só superfície? Como, numa só visada, sobrepor todas as miradas e criar uma perspectiva individual? Estou sempre sujeita à cidade, ou ela é que se instala em mim? Ou isso tudo é pura ilusão subjetiva?

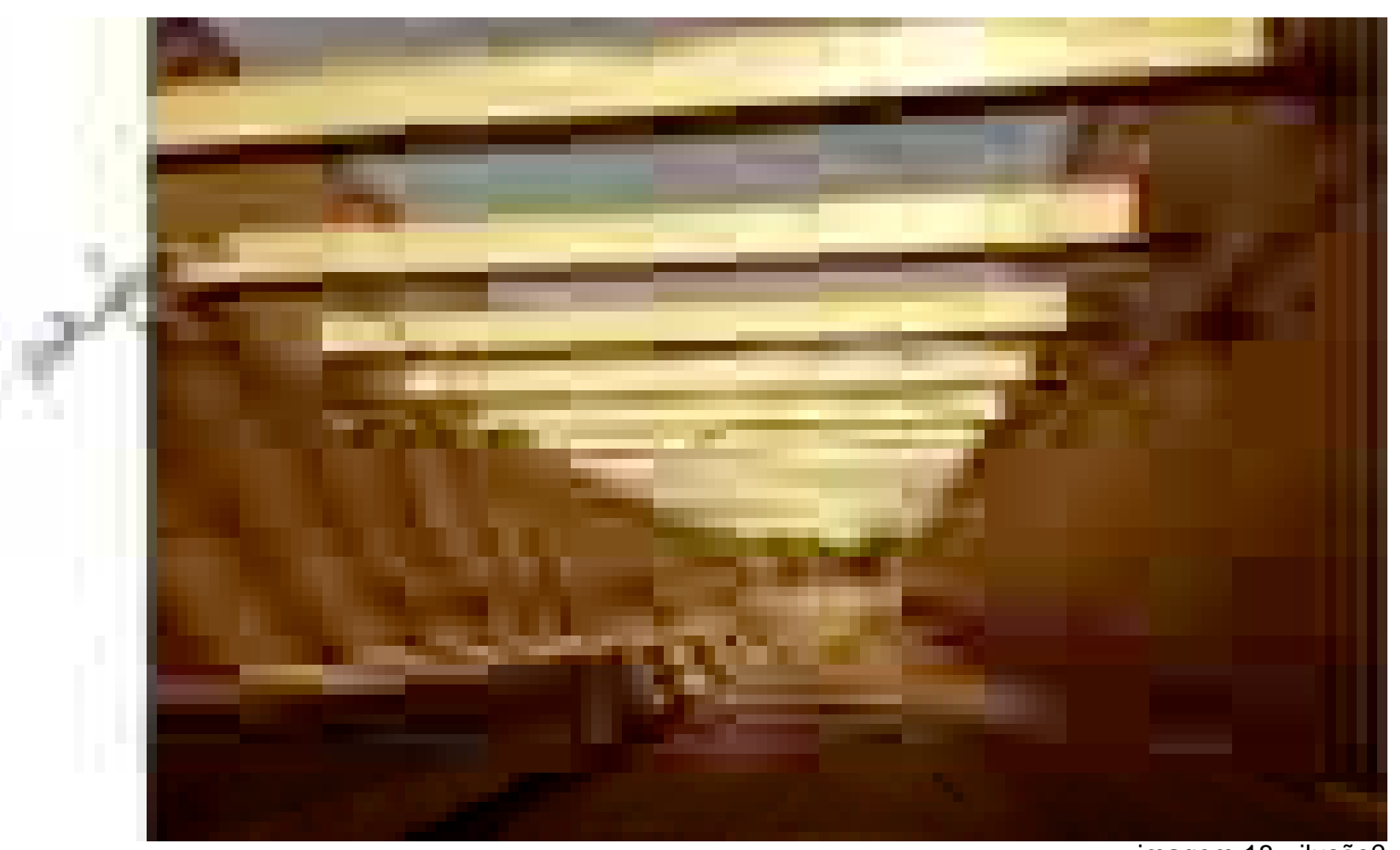

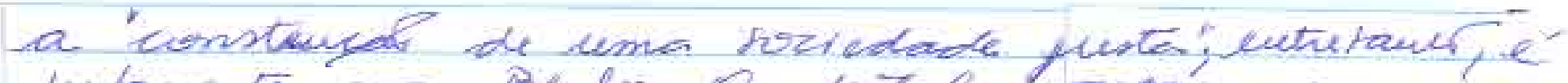

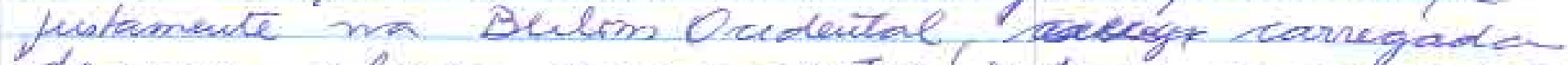

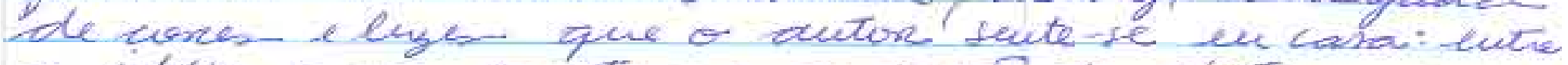

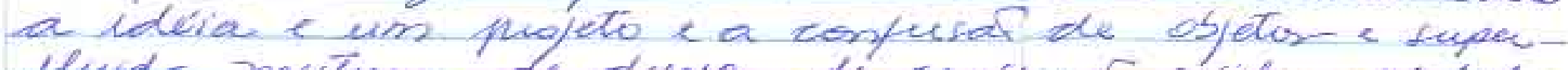

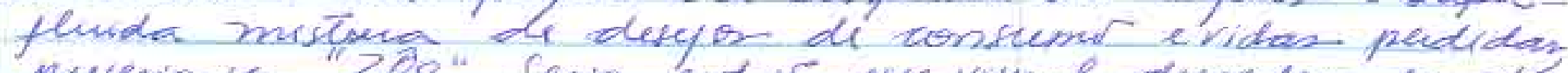

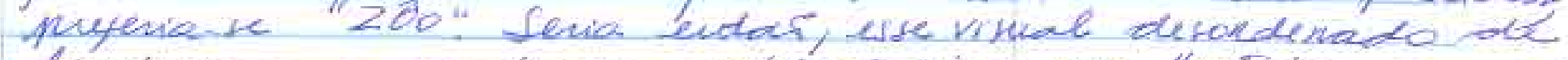

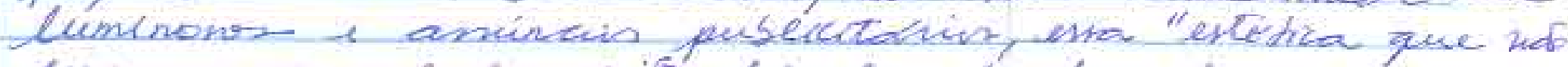

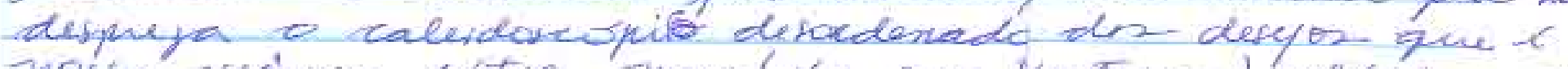

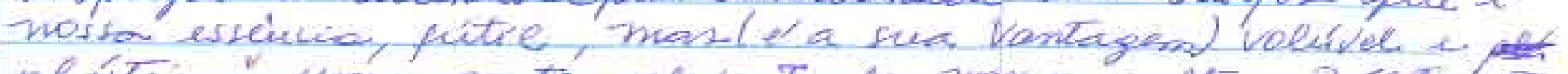

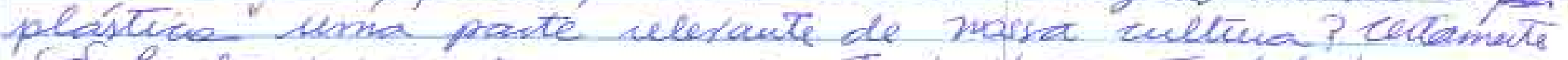

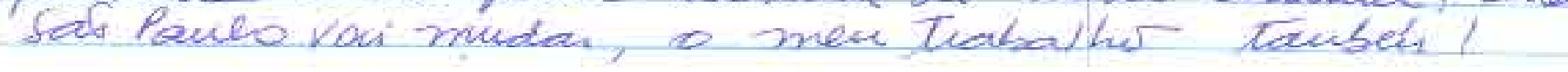




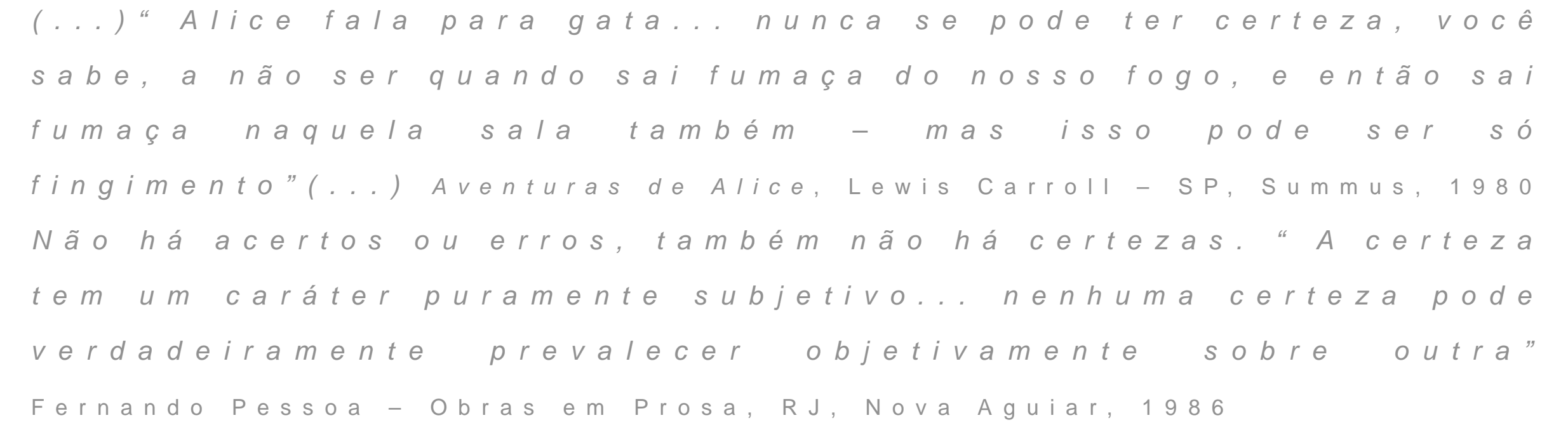


6. acidentes na rotina

"O homem provavelmente é a espécie mais misteriosa do planeta. Um mistério de perguntas sem respostas. Onde estamos? De onde viemos? Para onde vamos? De onde sabemos o que achamos que sabemos? Como acreditamos nas coisas? Inúmeras perguntas em busca de uma resposta. Uma resposta que levará a outra pergunta... cuja resposta levará à outra pergunta e assim por diante. Mas no final, não é sempre a mesma pergunta? E sempre a mesma resposta? A bola é redonda, o jogo dura 90 minutos. Isso é um fato. Todo oresto é teoria... ( introdução do filme Corra Lola, Corra) 
"Estar no universo fotográfico implica viver, conhecer, valorizar e agir em função de fotografias. Isto é: existir em mundo-mosaico. Vivenciar passa a ser recombinar constantemente experiências vividas através de fotografias. Conhecer passa a ser elaborar colagens fotográficas para se ter visão de mundo". FLUSSER, Vilém, Filosofia da Caixa Preta: ensaios para uma futura filosofia da fotografia, Relume/ Dumará, Rio Janeiro 2002 
"A vida não é a que a gente viveu, e sim a que a gente recorda e como recorda para contá- la "34

Em determinados momentos, a criação ocorre por uma conjunção de acidentes, logo, acasos e erros convertem-se em procedimentos constituintes do trabalho e talvez mereçam ser mais detidamente discutidos.

O uso da câmera fotográfica para registrar sensações da visualidade pressupõe muitas variáveis, e a escolha dentre elas já constitui uma atividade operativa: intervenção no enquadramento, no tempo de exposição do filme ${ }^{35}$, na abertura do diafragma ${ }^{36}$ e no tipo de material e equipamento a ser utilizado ${ }^{37}$.

Quando se está a pé na cidade e a lentidão é maior, pode-se usar a câmera reflex analógica (uso uma Rolleiflex) que, apesar de exigir mais atenção para as combinações de foco/ velocidade/ asa (sensibilidade do filme), possibilita a obtenção de maior qualidade quanto à luminosidade, à saturação

34 Gabriel Garcia MARQUES. Viver para Contar, p. 05.

35 A principal função do obturador é controlar a luz que atinge o filme: enquanto ele está fechado, o filme não é atingido pela luz, e quando se aciona o propulsor, ele se abre. Quanto mais tempo o obturador permanece aberto, mais luz atinge o filme.

36 O controle da abertura em geral é feito através de um anel situado na armação da objetiva. Conforme ele é girado uma série de lâminas superpostas abrem-se ou fecham-se a fim de mudar a quantidade de luz que atravessa a lente. Esse mecanismo denomina-se "diafragma",e o orifício através do qual passa a luz, "abertura".(Michael BUSSELLE, Tudo sobre Fotografia)

37 As câmeras utilizadas ao longo deste trabalho são: Olympus IS-50, Rolleiflex SL35, Hasselblad $500 \mathrm{c} / \mathrm{m}$, Sony Cyber-Shot DSC-P9 $4.0 \mathrm{mp}$ e Nikon D70. A Olympus IS-50 $35 \mathrm{~mm}$ é uma máquina automática com um obturador de plano focal. A Rolleiflex SL35 é uma câmera reflex monobjetiva que utiliza também utiliza filme de $35 \mathrm{~mm}$. Seu mecanismo é manual, o que permite alterações no seu manuseio. A Hasselblad $500 \mathrm{c} / \mathrm{m}$ é uma câmera reflex monobjetiva de formato grande. $O$ filme em rolo(120 mm), é acondicionado em um chassi traseiro intercambiável. No visor de capucho, a imagem formada sobre a retícula é invertida em sentido lateral. A Sony Cyber-Shot DSC-P9 é uma câmera digital automática com dispositivo de imagem CCD a cores de 8,98 mm equipada com uma lente de zoom automático f=8-24,0mm. Por fim, a Nikon D70 é câmera reflex digital de lentes intercambiáveis. 
de cores e à definição da imagem; a máquina digital, por ser mais leve e automática, é utilizada nos momentos em que é exigida prontidão, velocidade para capturar imagens; no trânsito, a vista que se poderá ter da cidade já sofre enquadramentos prévios pelas janelas e vidros do automóvel. Com o carro em movimento, muitas vezes, nem se pode olhar o que a máquina vai capturando "às cegas".

Minha experiência com a fotografia na cidade começou com o uso de uma câmera quebrada38 e foi a partir daí que passei a dar mais atenção às possibilidades poéticas que se encontram por trás do erro e do acaso.

38 Um imprevisto danificou o obturador da máquina automática Olympus IS-50, o que possibilitou uma peculiar sensibilização da película fotográfica. O mecanismo deste obturador baseia-se num sistema de duas cortinas metálicas de movimento vertical, situado diretamente na frente do filme. A cortina metálica partiu, e aconteceu... atrás da cortina preta é o trabalho que deu inicio ao meu "fazer fotográfico". Com um filme de alta sensibilidade, Fujicolor Superia 400 (O filme negativo colorido, tipo luz do dia, de alta sensibilidade ISO 400 apresenta alto contraste e alta saturação de cores, que proporcionam imagens vivas e brilhantes. O seu uso é indicado para câmeras fotográficas automáticas como a Olympus IS-50), foram registradas as cenas urbanas. Depois de revelado normalmente, algumas imagens foram ampliadas nas dimensões de $125 \times 84 \mathrm{~cm}$, em papel fotográfico brilhante e, posteriormente, montadas em placa de PVC branco de $3 \mathrm{~mm}$. O acidente instigou para o conhecimento do aparelho e das múltiplas sensibilidades dos filmes. Isso gerou uma multiplicação de formas de impressionar o filme, antes desconhecidas. O olho é incapaz de adivinhar aonde a falha do obturador se revelará após a captação da imagem, o visor permanece inalterado.

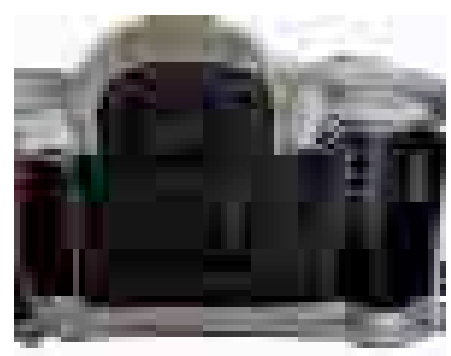

obturador normal

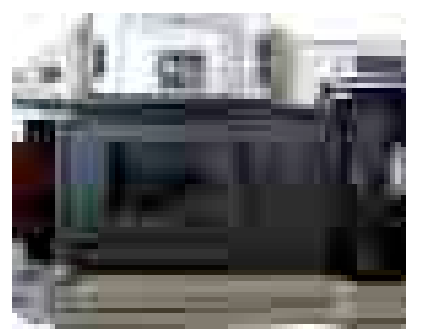

obturador danificado 
Tratar expressivamente a rotina na cidade que impõe desvios repentinos de percursos e conduz a perspectivas visuais desconhecidas de um momento para o outro (há irrupção de novos luminosos e outdoors, brotam subitamente inscrições em paredes inteiras ou em edifícios sóbrios e monumentos públicos...) significa conservar uma espécie de reserva de experiências visuais desconhecidas de um momento para o outro (há irrupção de novos luminosos e outdoors, brotam subitamente inscrições em paredes inteiras ou em edifícios sóbrios e monumentos públicos...) significa conservar uma espécie de reserva de experiências visuais tanto imaginadas ou inventadas e produzidas, quanto vividas efetivamente, e é somente desses pontos de vistas plurais especulares que reflito materialmente os espaços urbanos, públicos e privados.

As possisilidades epvestivar da fotopatia de Mon Day agucauam minha

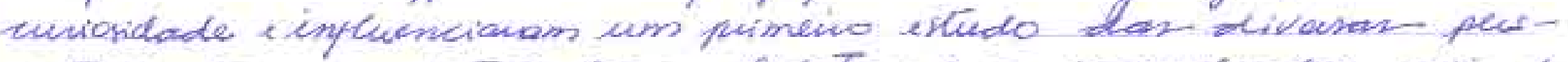

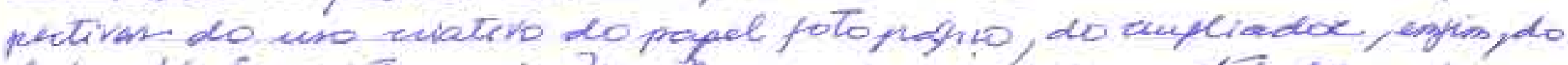

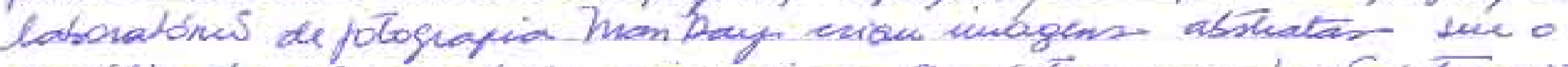

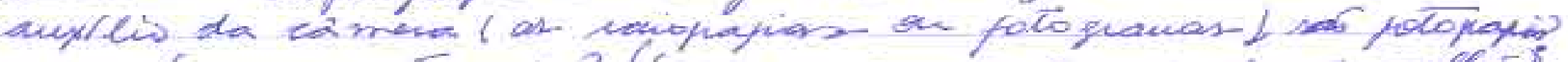

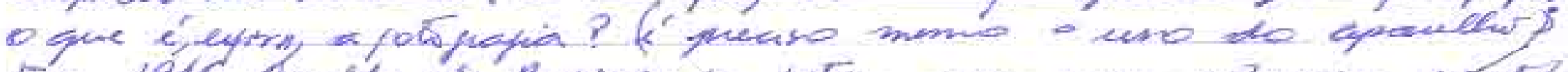

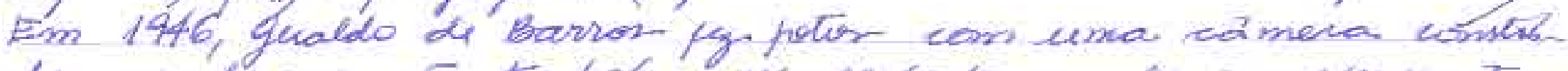

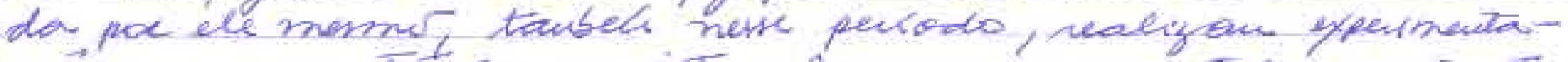

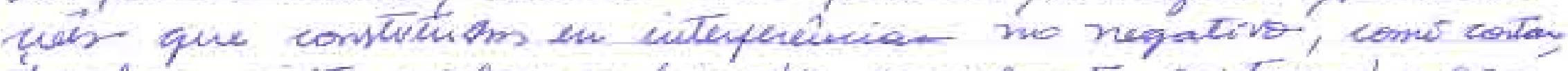

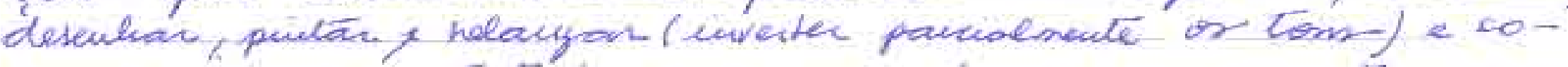
prepere imagens. Estude cada um desses procedimentos, fiz.

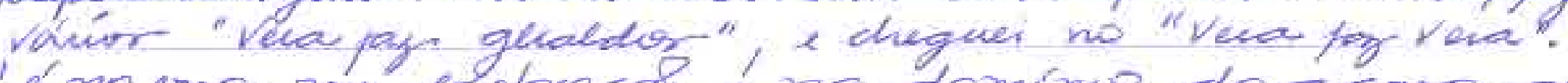
"l' noerno, na efplorach é no domino do acaso, que

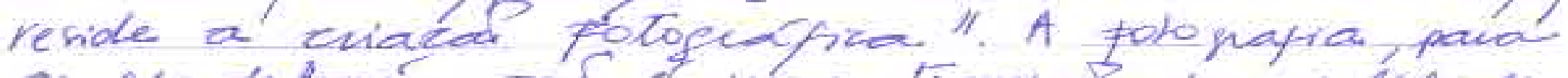

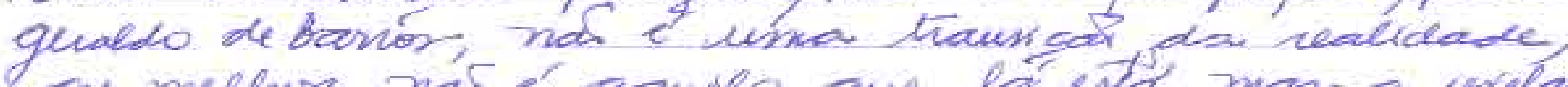
ou mellwe, nár é aquild que la'estó, mas a crelacol

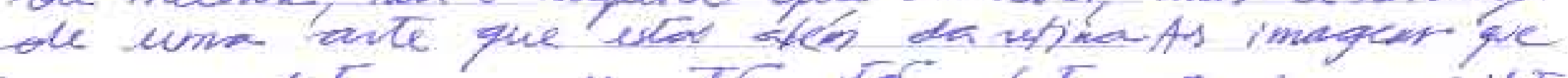

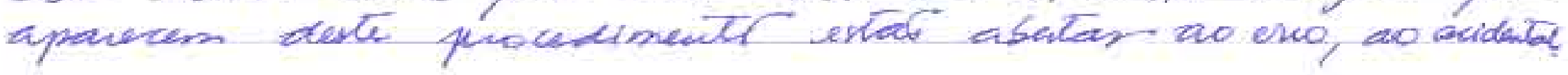

69 

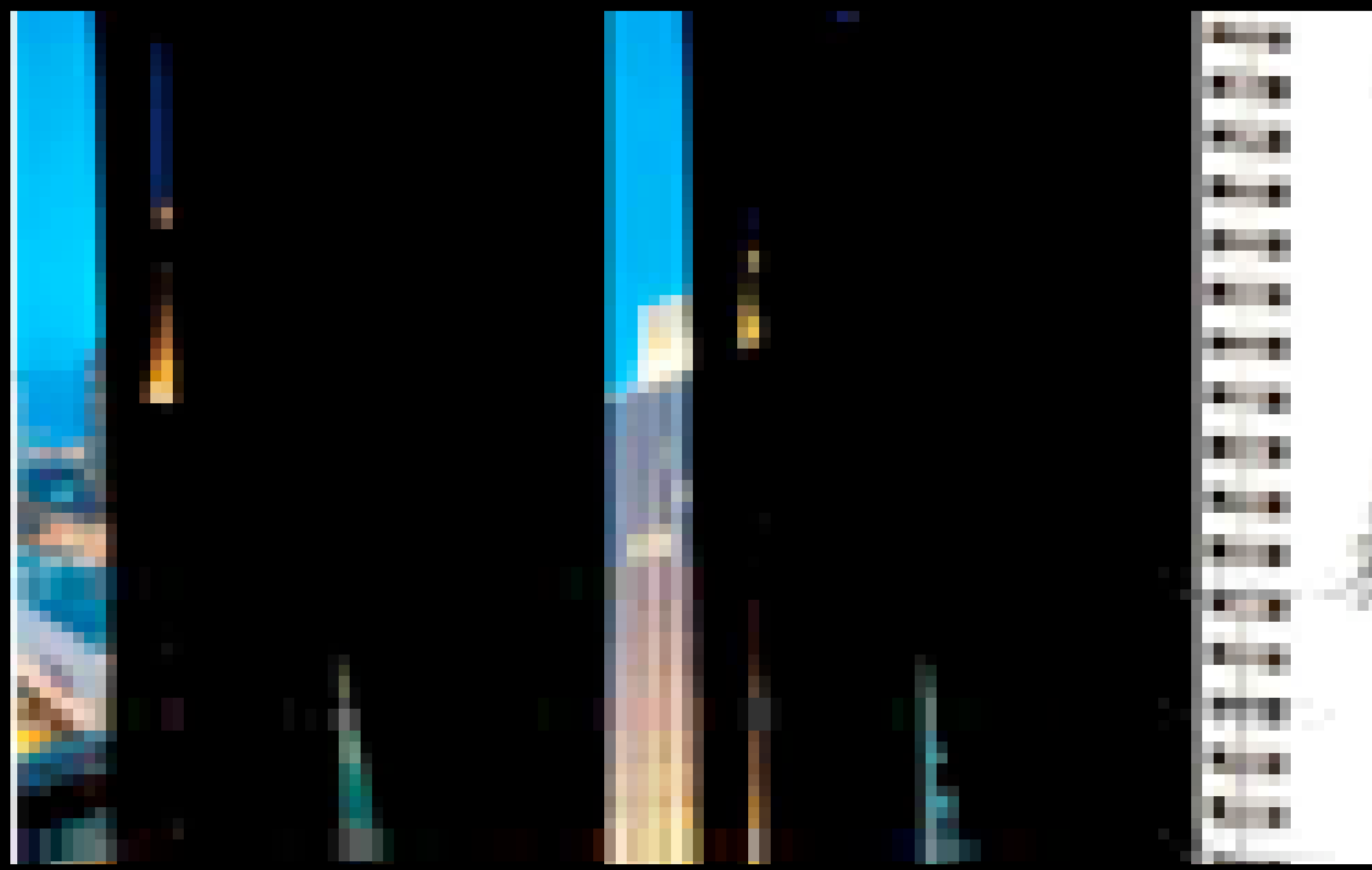

imagem 19 - anatações para atrás da cortina preta 


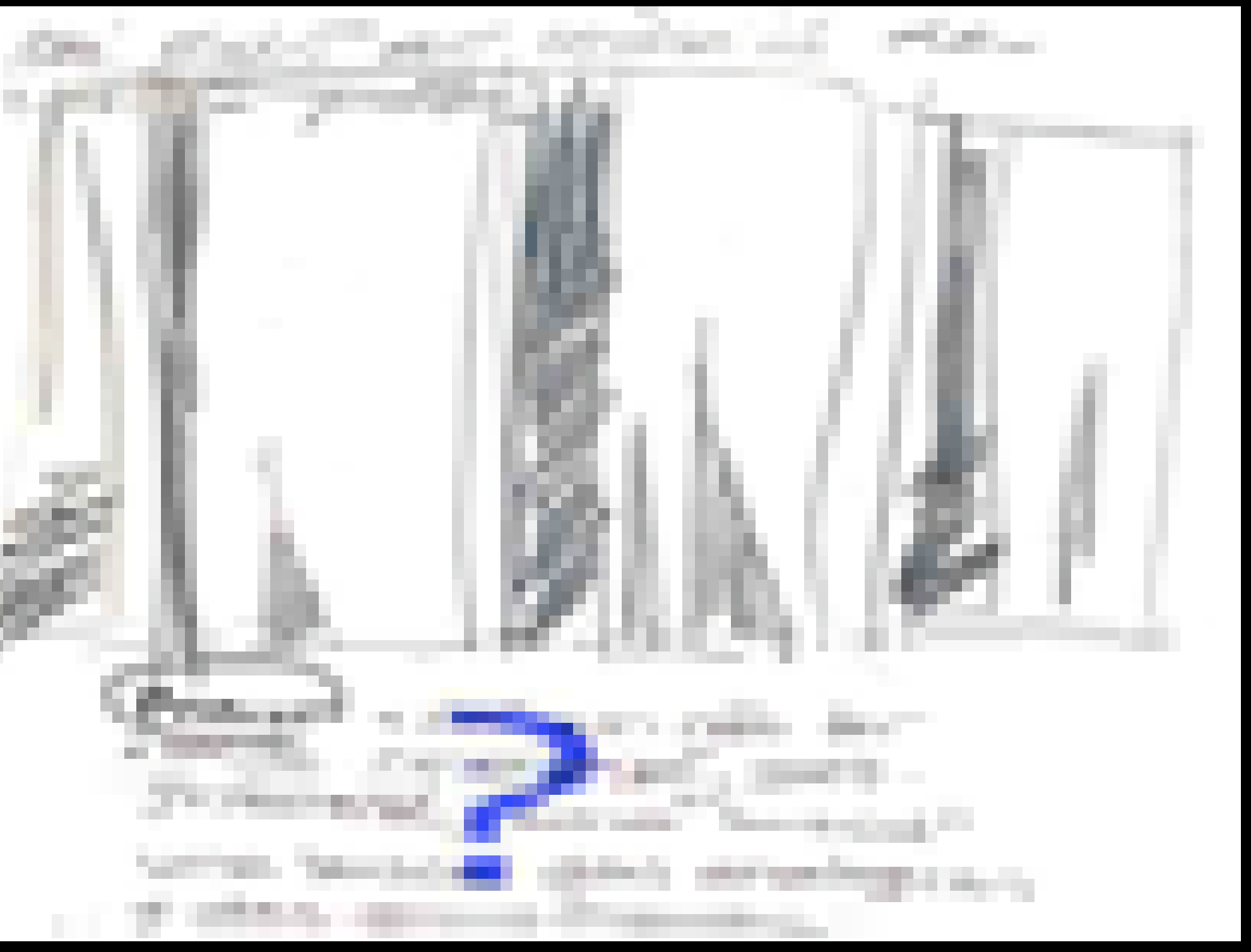


O movimento imprime-se pela luz na matéria fotossensível do filme, "entreimagens"; as manchas traçadas e os fantasmas apresentam-no: são informações de dissolvências. Cada registro de deslocamento é experimentação de mecanismos técnicos para a experimentação de uma existência estética

No caso de além da cortina preta, retomar o percurso inverso dos seus procedimentos formativos abrange um esforço de complexa escavação não linear do tempo, que é simultaneamente uma experiência de desestratificação pessoal. Trata-se de conceber uma geologia, um estudo da formação das sucessivas transformações da subjetividade/ cidade constituída por sobreposição e justaposição de camadas territoriais de imagens. Essas imagens estão, simultaneamente, em contínua composição/ estratificação e decomposição/ desestratificação. São vistas plurais, captadas, digitalizadas em camadas, metamorfoseadas, intensificadas, acumuladas e comprimidas numa única impressão, cuja dimensão corresponde ao deslocamento mínimo necessário para provocar a sensação de imersão. Uma dimensão que não pode ser abarcada de um só golpe, de uma só "visada", é necessário deslocar-se para experimentá-la.

além da cortina preta é um conjunto de imagens compostas de outras imagens de: sinalizações de trânsito, cartazes, muros escritos, edifícios, estabelecimentos, luzes, sombras, desenhos, gente, calçadas, chão, gráficos ou

Vefo, nas imagens de Wulr-

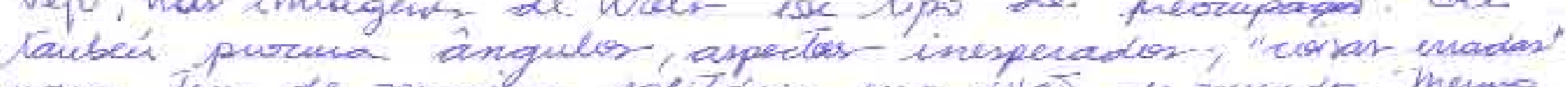

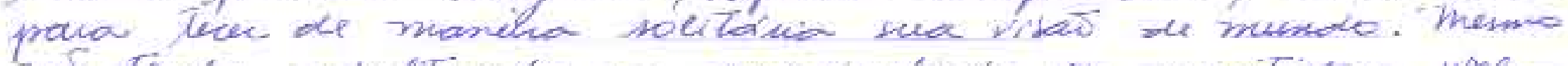

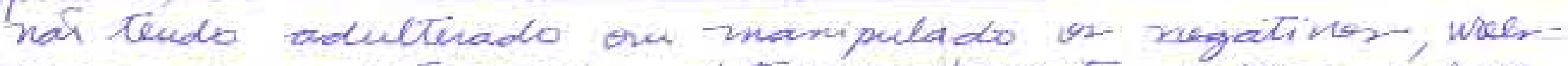

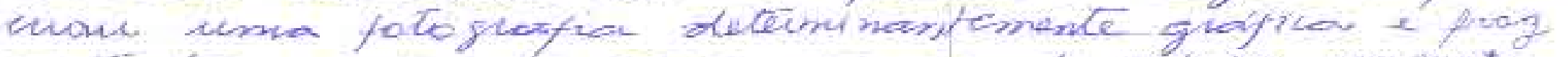

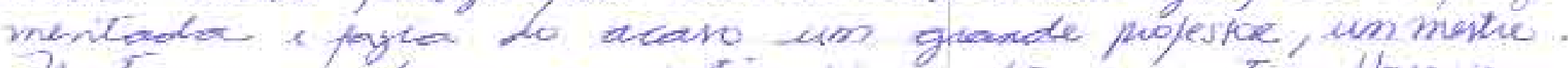

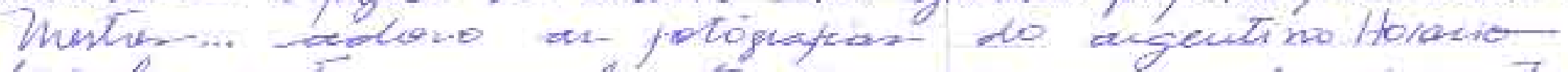

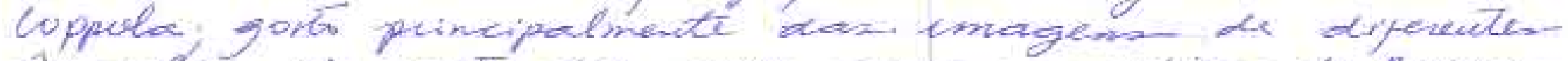

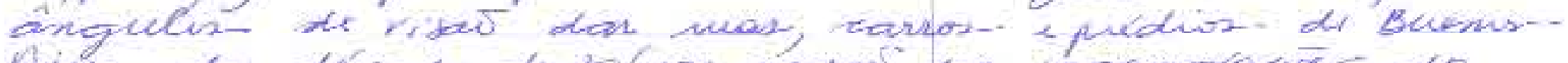

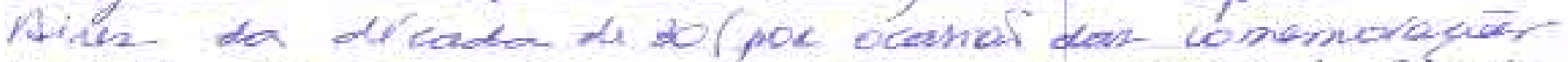

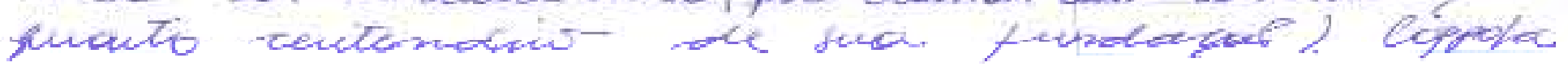


"graficáveis" da cidade que povoam, de relance, a experiência visual. Nada é tomado em sua individualidade ou em suas características descritivas e narrativas.

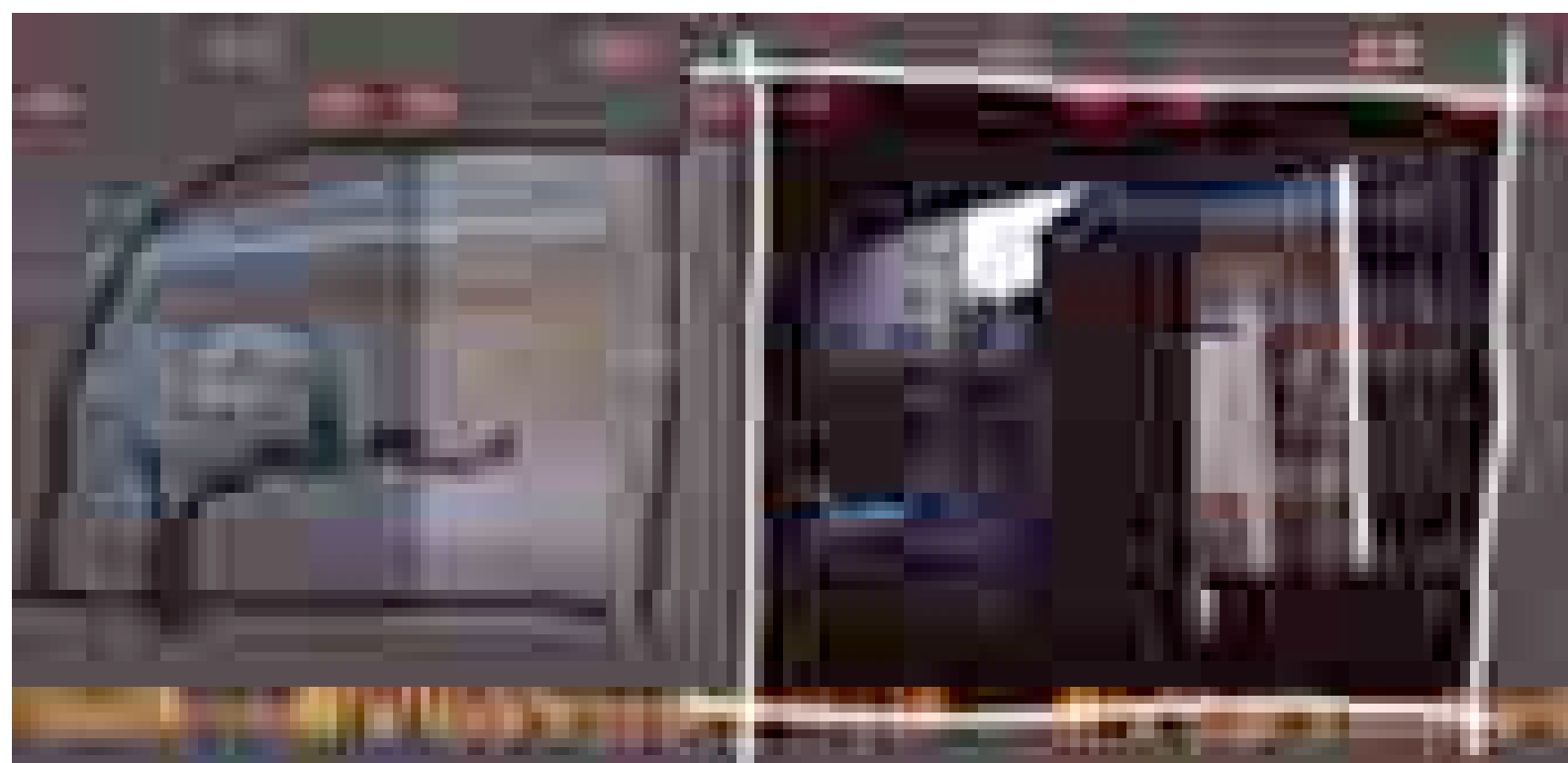

imagem 20 - enquadramento da janela do carro

O trabalho corresponde à sensação de uma tomada de fôlego e subseqüente imersão na realidade normal cotidiana: visualidade líquida. É uma respiração presa, enquanto percorro, fluindo "liquidamente", o fundo de um lago/ cidade, infiltrando-me, desde o ponto de partida até o ponto de chegada, em lugares preestabelecidos determinados pelas regras circunstanciais.

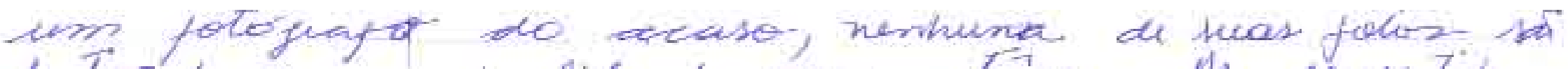
fuito de ina pasualidade rnomentanea. As perspetivan-

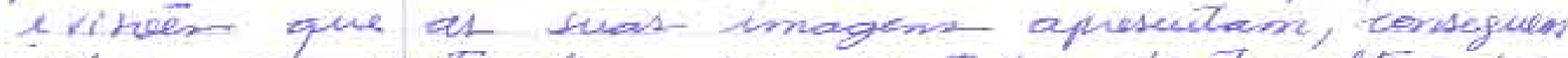
Ablar as particulas spanfratilas do tumula da

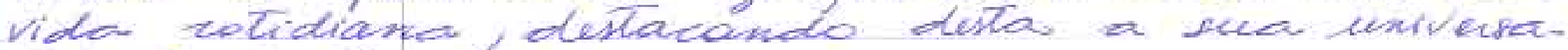

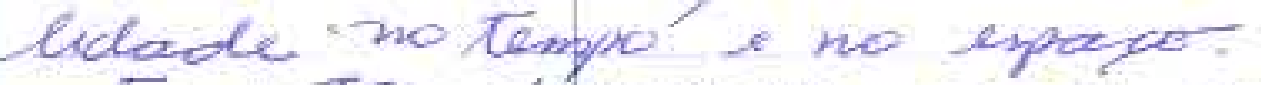

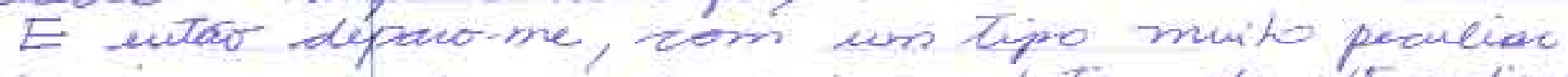

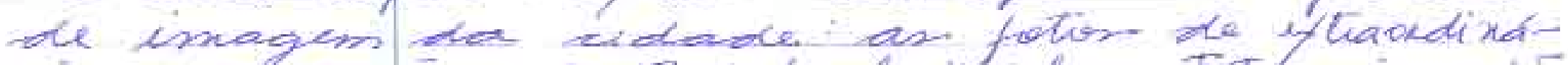

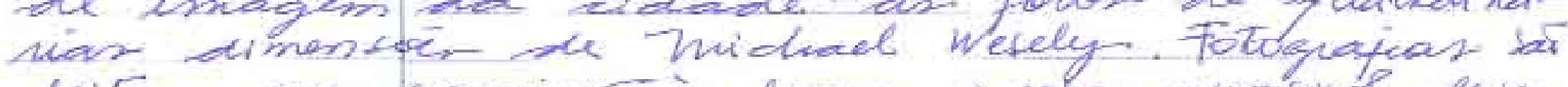

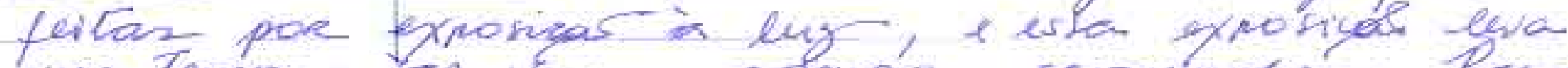

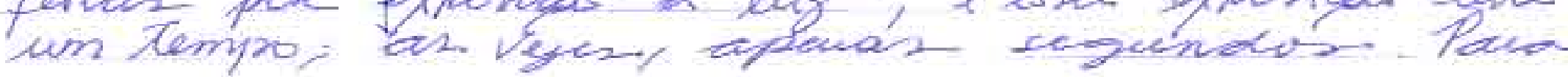


A observação da cidade é de dentro dela, mas além da cortina preta é o trabalho de tornar a decorrência dessa observação duplamente interna - de dentro para dentro, em mim - uma pura exterioridade, mas imersa invaginação da exterioridade que me torna individual.

Submersa no meio da cidade e de relance, procuro encontrar não o edifício, mas um plano de cor vertical; não uma faixa de trânsito, mas um plano rítmico, não as ruas ou calçadas, solo firme sobre o qual se pode andar, mas extensões intercaladas por onde se pode passar.
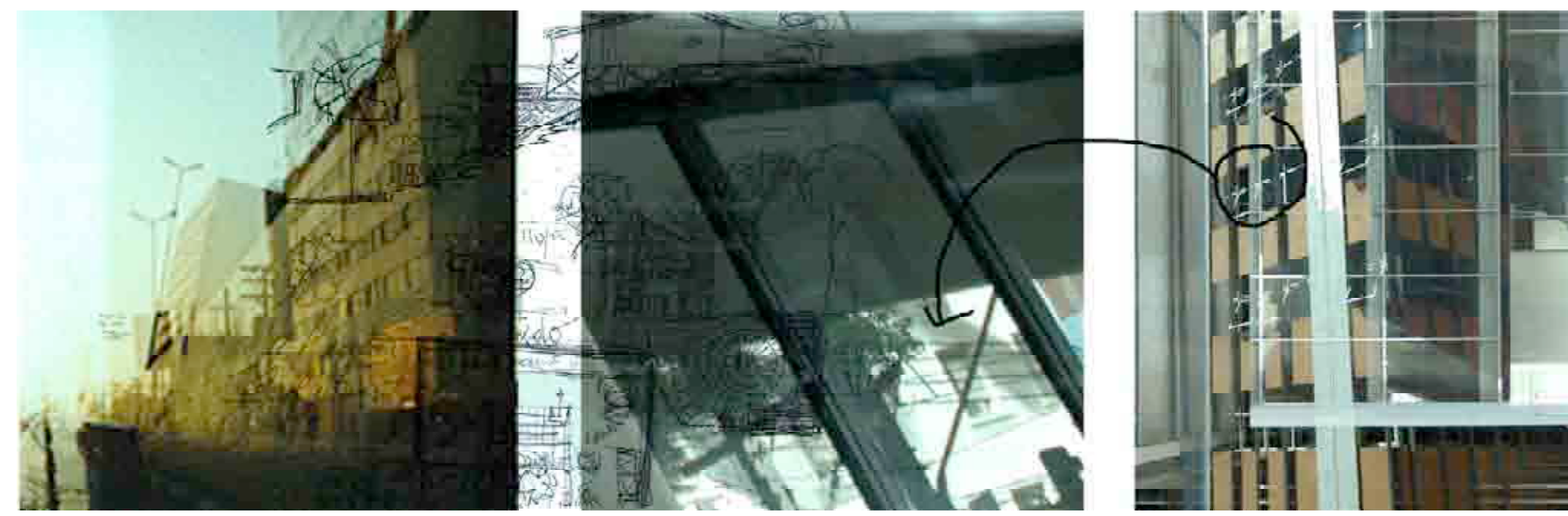

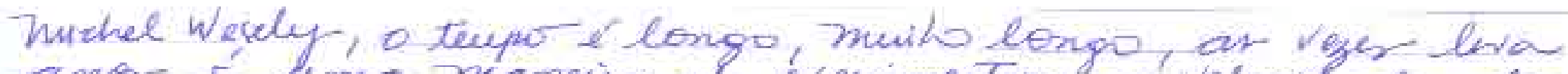
anor E luma maneisa de experimantac a velovidade da

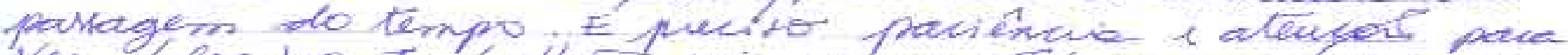

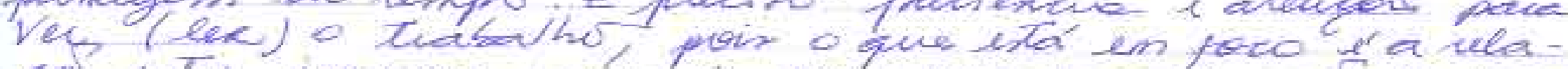

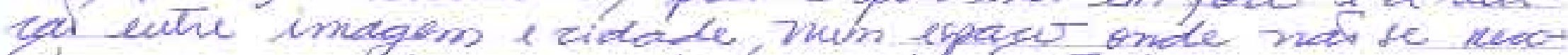

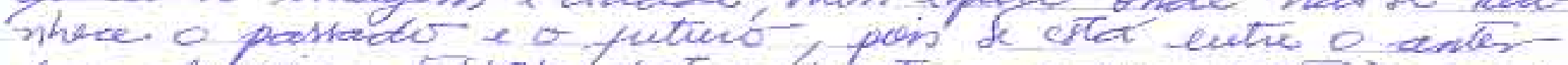

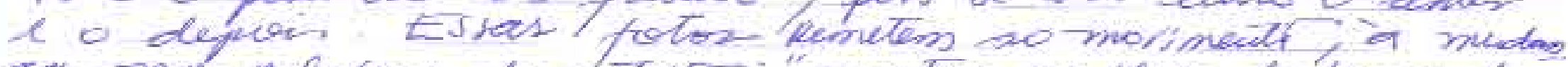

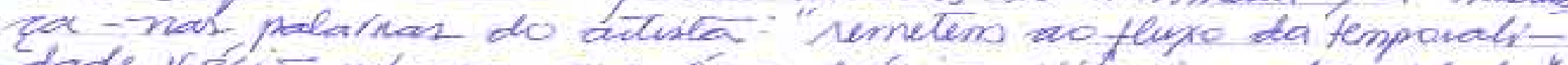

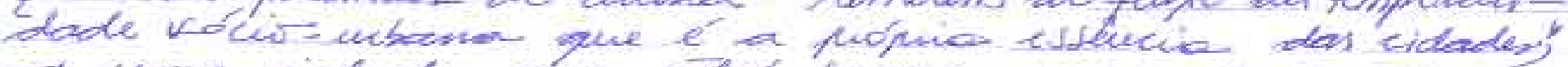

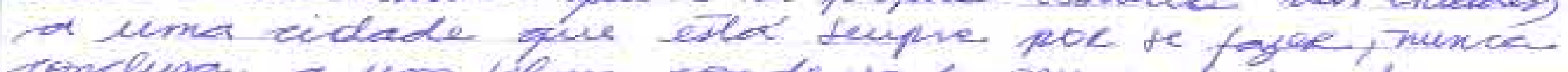

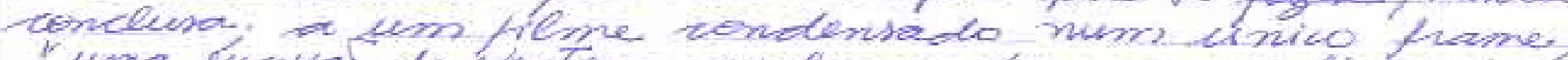

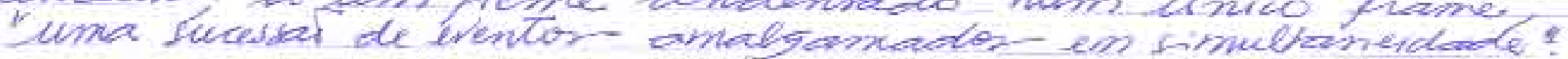


além da cortina preta são polifonias da cidade empilhadas em planos comunicantes e em camadas de contra-informações ${ }^{39}$ que se amontoam desfazendo pré-visões futuras; é o texto visual que uma Penélope atualizada vive a tecer numa "tramação" inesgotável de urgências mais urgentes.

Haveria ainda, como sugerira o flâneur, outras reconstruções subjetivas dessa cidade atual? Talvez, para mim, novas possibilidades apresentem-se apenas por meio de infiltrações de luz, além da cortina preta...

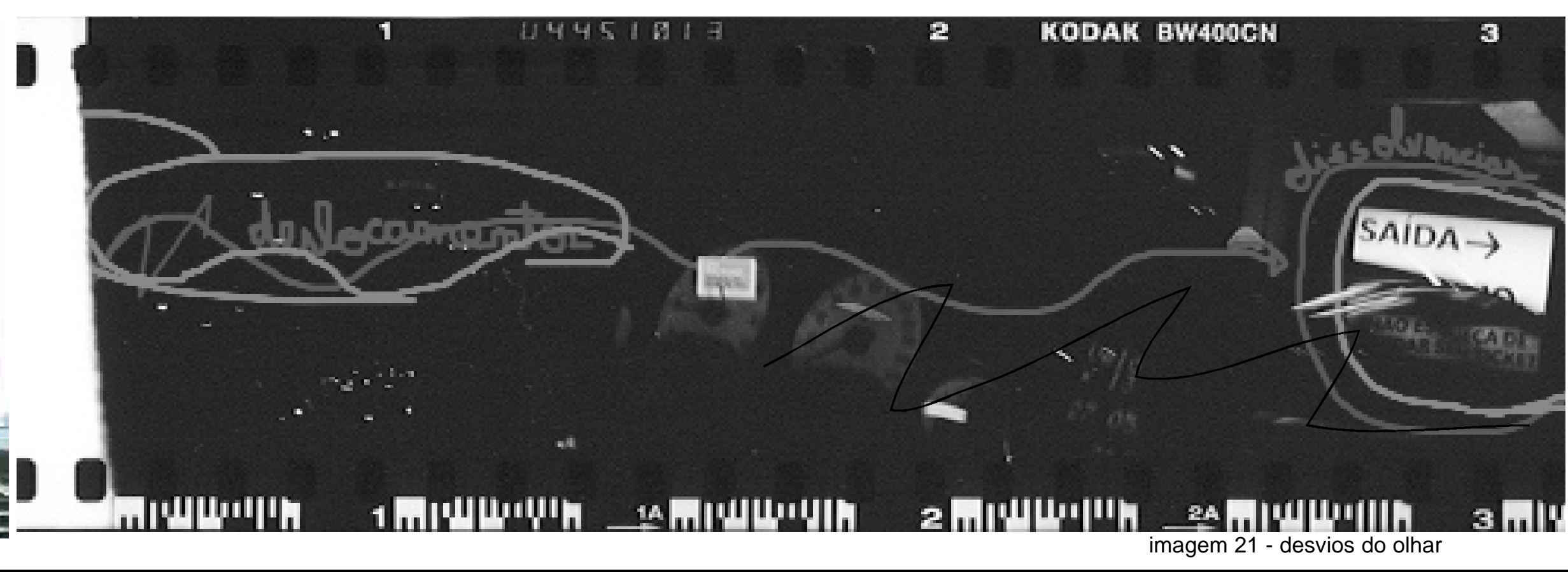

39 "... uma via expressa construída sobre o rio, recoberta por um jardim. O vale, o viaduto e os grandes edifícios vão acrescentando outras camadas num verdadeiro palimpsesto urbano". (Nelson Brissac PEIXOTO. Paisagens Urbanas, p. 3.). 
Toda Sexta-feira à noite começa o Shabat para a tradição judaica. Shabat é o conceito que propõe descanso ao final do ciclo semanal de produção, inspirado no descanso divino no sétimo dia da Criação. Muito além de uma proposta trabalhista, entendemos a pausa como fundamental para a saúde de tudo o que é vivo. A noite é pausa, o inverno é pausa, mesmo a morte é pausa. Onde não há pausa, a vida lentamente se extingue. Para um mundo no qual funcionar 24 horas por dia parece não ser suficiente, onde o meio ambiente e a terra imploram por uma folga, onde nós mesmos não suportamos mais a falta de tempo, descansar se torna uma necessidade do planeta. Hoje, o tempo de 'pausa' é preenchido por diversão e alienação. Lazer não é feito de descanso, mas de ocupações 'para não nos ocuparmos'. A própria palavra entretenimento indica o desejo de não parar. E a incapacidade de parar é uma forma de depressão. $O$ mundo está deprimido e a indústria do entretenimento cresce nessas condições. Nossas cidades se parecem cada vez mais com a Disneylândia. Longas filas para aproveitar experiências pouco interativas. Fim de dia com gosto de vazio. Um divertido que não é nem bom nem ruim. Dia pronto para ser esquecido, não fossem as fotos e a memória de uma expectativa frustrada que ninguém revela para não dar o gostinho ao próximo... Entramos no milênio num mundo que é um grande shopping. A Internet e a televisão não dormem. Não há mais insônia solitária; solitário é quem dorme. As bolsas do Ocidente e do Oriente se revezam fazendo do ganhar e perder, das informações e dos rumores, atividade incessante. A CNN inventou um tempo linear que só pode parar no fim. Mas as paradas estão por toda a caminhada 
e por todo o processo. Sem acostamento, a vida parece fluir mais rápida e eficiente, mas ao custo fóbico de uma paisagem que passa. O futuro é tão rápido que se confunde com o presente. As montanhas estão com olheiras, os rios precisam de um bom banho, as cidades de uma cochilada, o mar de umas férias, o Domingo de um feriado... Nossos namorados querem 'ficar', trocando o 'ser' pelo 'estar'. Saímos da escravidão do século XIX para o leasing do século $X X I$ - um dia seremos nossos? Quem tem tempo não é sério, quem não tem tempo é importante. Nunca fizemos tanto e realizamos tão pouco. Nunca tantos fizeram tanto por tão poucos. Parar não é interromper. Muitas vezes continuar é que é uma interrupção. O dia de não trabalhar não é o dia de se distrair - literalmente, ficar desatento. É um dia de atenção, de ser atencioso consigo e com sua vida. A pergunta que as pessoas se fazem no descanso é 'o que vamos fazer hoje?' - já marcada pela ansiedade. E sonhamos com uma longevidade de 120 anos, quando não sabemos o que fazer numa tarde de Domingo. Quem ganha tempo, por definição, perde. Quem mata tempo, fere-se, mortalmente. É este o grande 'radical livre' que envelhece nossa alegria: - o sonho de fazer do te mpo uma mercadoria. Em tempos de novo milênio, vamos resgatar coisas que são milenares. A pausa é que traz a surpresa e não o que vem depois. pausa é que dá sentido à caminhada. A prática espiritual deste milênio será viver as pausas. Não haverá maior sábio do que aquele que souber quando algo terminou e quando algo vai começar. Afinal, por que o Criador descansou? Talvez porque, mais difícil do que iniciar um processo do nada, seja dá-lo como concluído... (Nilton Bonder) 

O porte de uma máquina fotográfica na cidade é algo muito comum: nada é mais corriqueiro do que testemunhar alguém "tirando fotos" por aí. Um lugar tão afeito às imagens parece estimular a própria ação de captura delas, assim como uma resposta que se dá a uma questão qualquer sobre qualquer coisa.

A diferença em relação ao meu trabalho está em uma função que não é informativa. As imagens que eu capturo nunca servem como pontos referenciais ou "localizadores" - não se trata de explorar a "iconografia paulistana". O trabalho ocorre pela potencialização das propriedades estéticas e metamórficas dos grandes centros urbanos, que têm a efemeridade como característica comum: ninguém pode indicar o endereço de sua casa ou de seu escritório a partir de "pontos" que, no dia seguinte, poderão não mais estar lá. Esses elementos só servem de orientação efêmera, no momento em que se está construindo um caminho provável, uma "rota de fuga", um "lançar-se imediato" para um destino possível - é o que ocorre quando, ao pararmos num posto de gasolina para pedirmos alguma informação, ouvimos: "está vendo aquela faixa amarela? Então, é logo ali!".

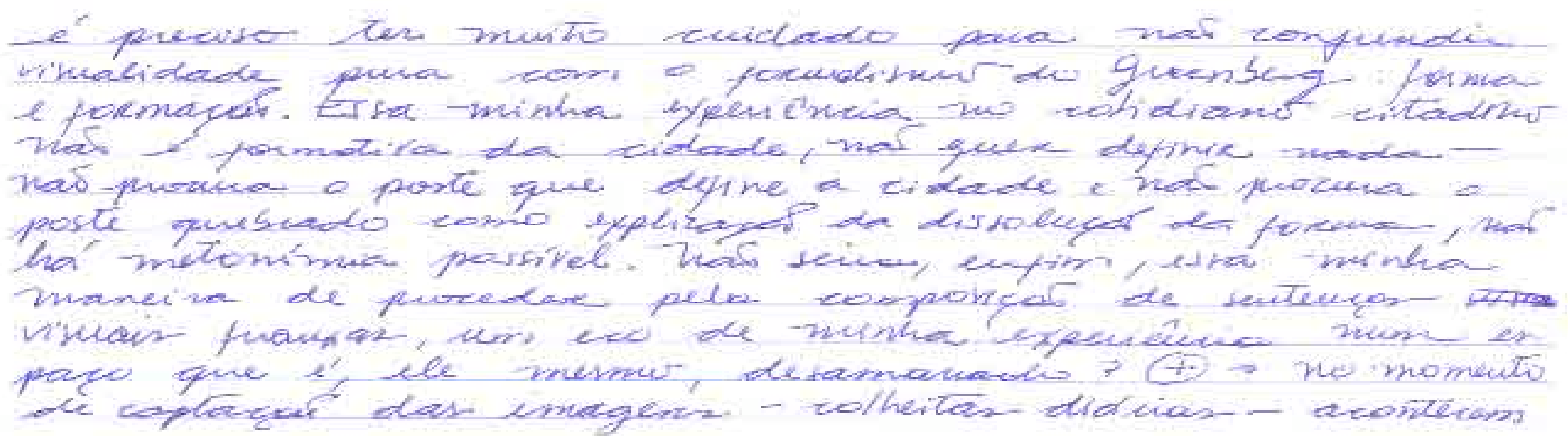


além da cortina preta não visa o monumento, aquilo que se individua na cidade, que tem vida longa e que se faz ponto referencial. O trabalho visa, desde o princípio, aquilo que não é referência alguma, mas que diz respeito às afecções e paixões experimentadas singularmente na cidade.

"Depois da árvore roxa que está em baixo do poste quebrado, virar à esquerda no semáforo ao lado do outdoor azul e, passando por detrás daquele ônibus, entrar naquele negócio verde em que o carro branco acabou de virar". Trata-se de uma experiência que existe, deixa de existir e transforma-se completamente, em pouquíssimos instantes e que se repete centenas e centenas de vezes em nosso dia a dia.

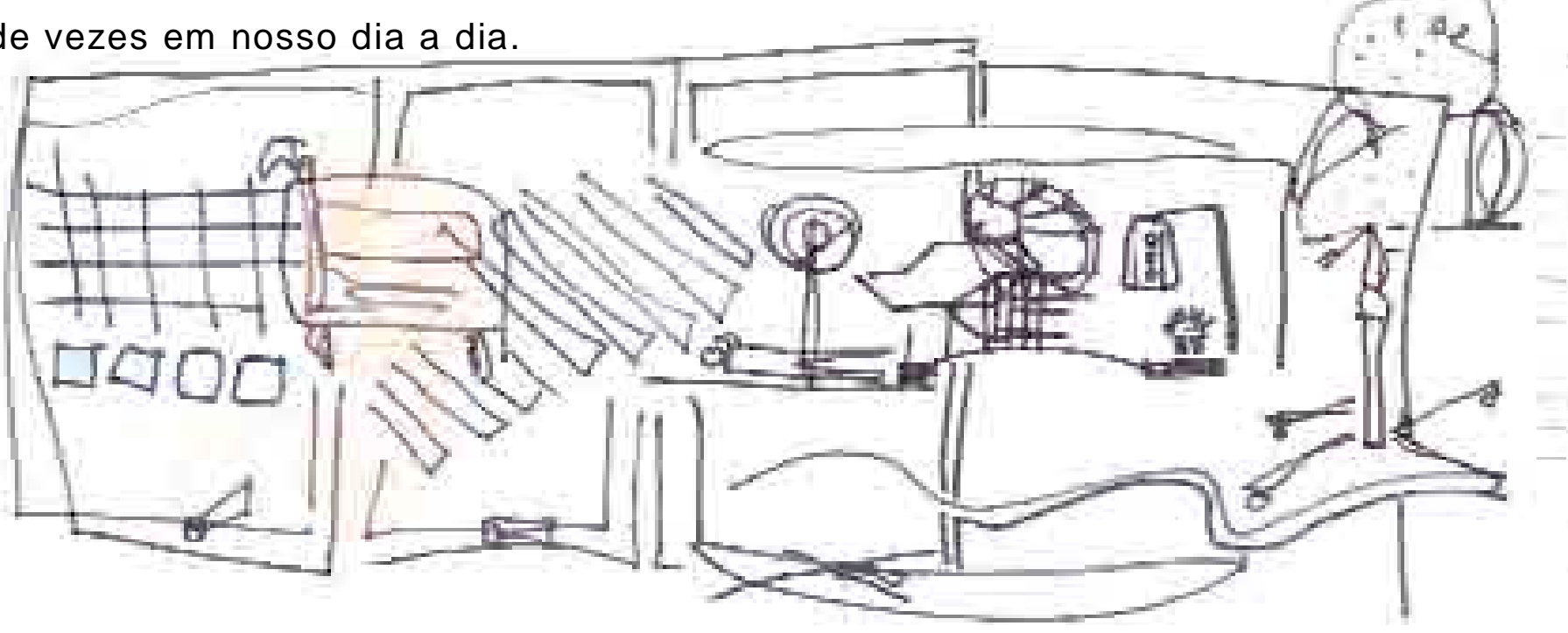

40 Eu estou dentro do teto no copo de água que vou beber, e estou dentro da construção que também está atrás de mim na janela do meu carro - a imagem congela coisas que existiram de fato.

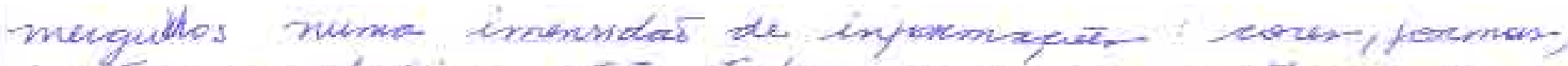

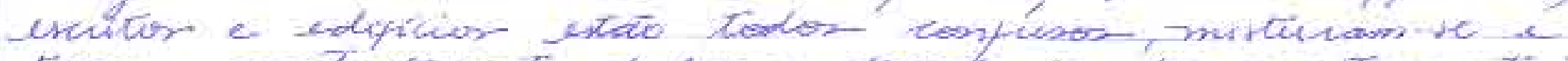

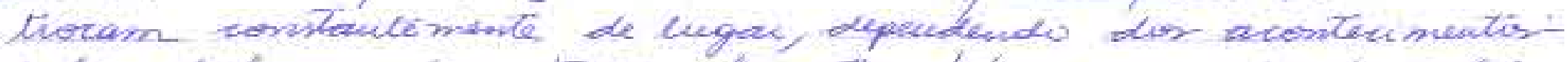

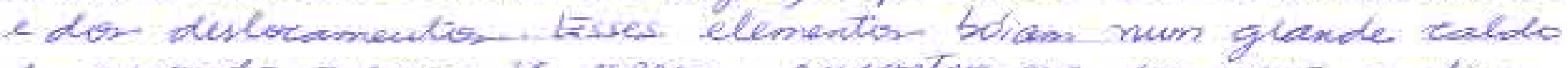

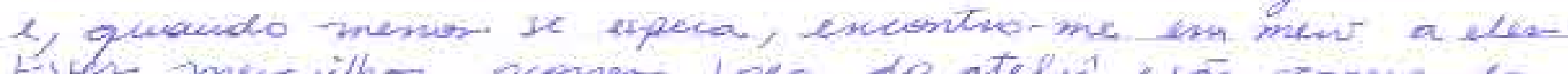

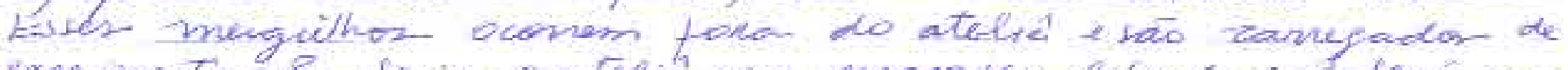

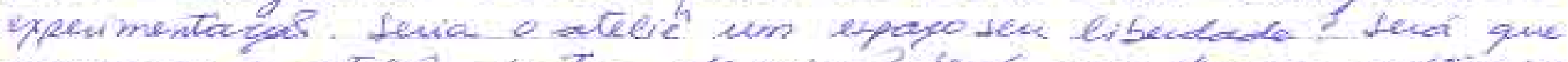

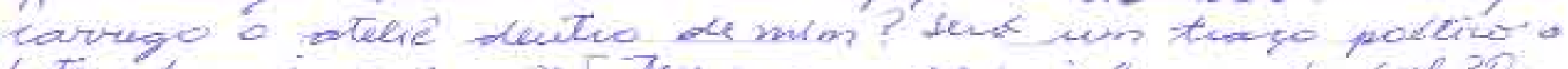

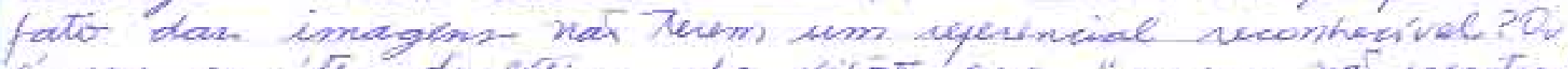

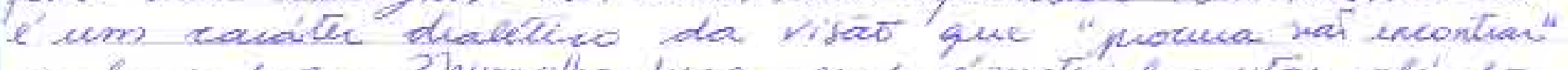

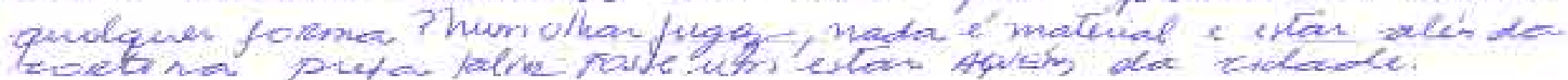


Tal experiência é o processo próprio formativo das imagens que compõem o trabalho e é nela e por ela que, igualmente, tomam corpo as impressões e sensações que são expressas materialmente: "o céu azul e quadriculado", "ônibus de barraca de água laranja cortado por faixa de pedestres", "homem de placa sob calçada no lado de cá da rua". São experiências tão comuns e banais quanto esperar um semáforo abrir ou o trânsito melhorar — de relance, nada existe tão decididamente.
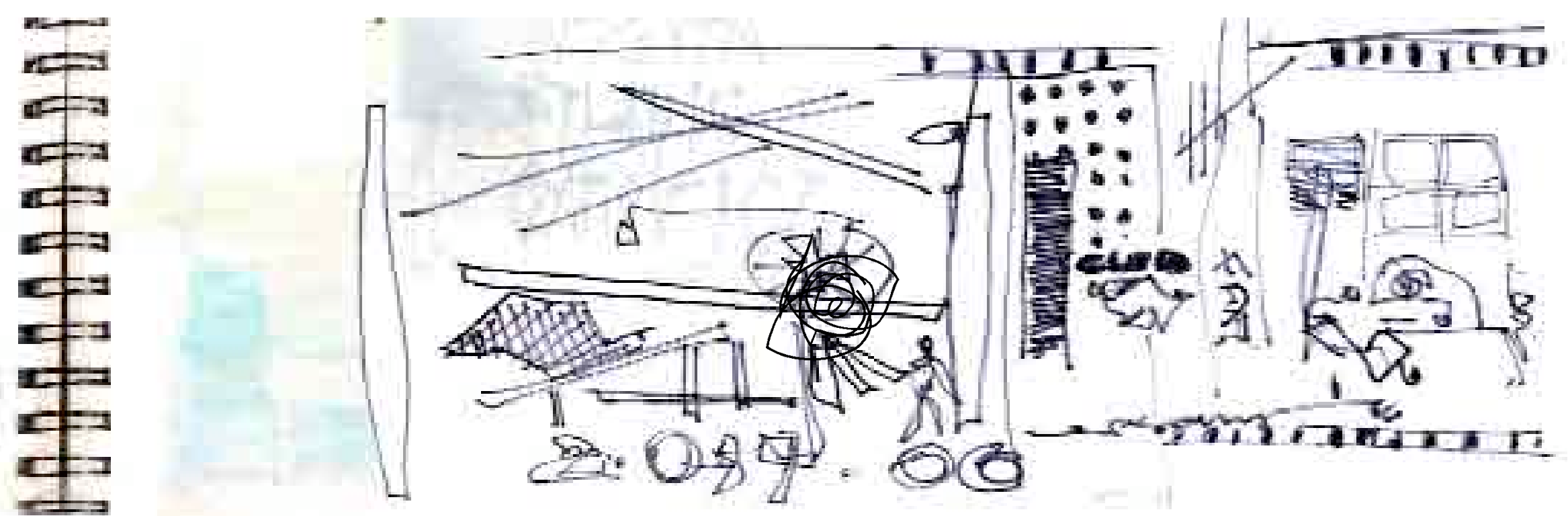

índice de imagens 

imagem

1.

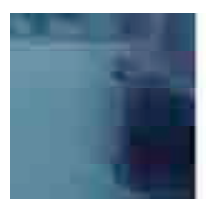

2.

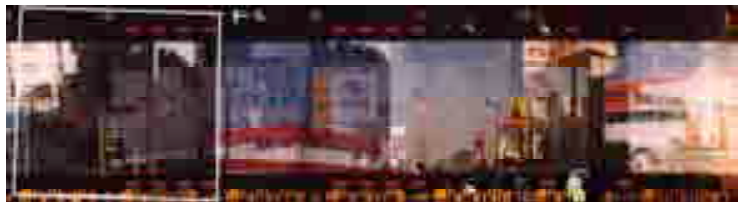

3.

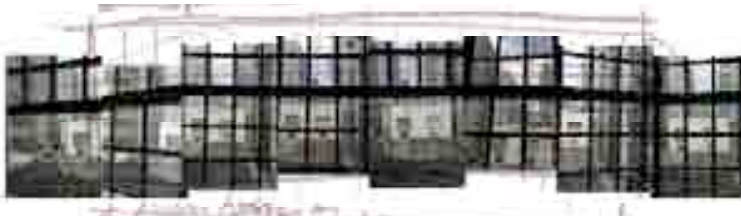

+

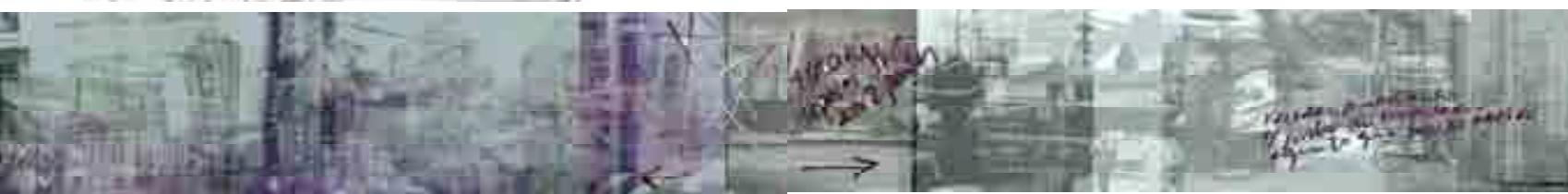

4

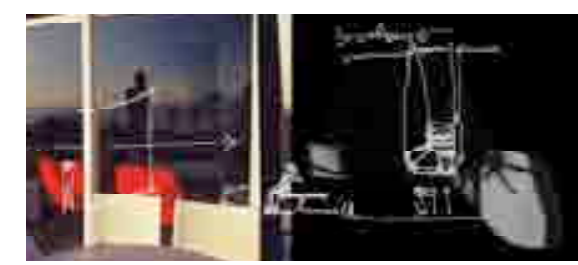

6.

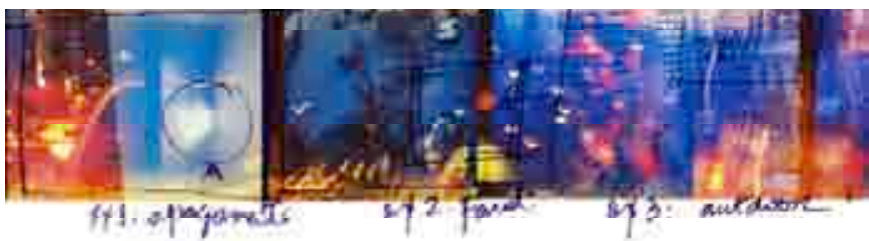

7.

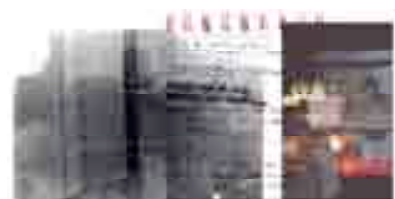

2003

$20 \times 20 \mathrm{~cm}$

sony cybershot

05

tira de negativo

2006

$4 \times 20 \mathrm{~cm}$

rolleiflex sl35

montagem digital

2005

$80 \times 370 \mathrm{~cm}$

nikon D70

montagem digital

2004

$20 \times 200 \mathrm{~cm}$

rolleiflex sl35

2004

$40 \times 50 \mathrm{~cm}$

rolleiflex sl35

2003

$40 \times 135 \mathrm{~cm}$

rolleiflex sl35

2003

$20 \times 30 \mathrm{~cm}$

rolleiflex sl35 
página

23

25

2005

$80 \times 640 \mathrm{~cm}$ nikon D70

27

49

49

51
2006

$40 \times 180 \mathrm{~cm}$

rolleiflex sl35

$2005 \quad 2003$

$50 \times 125 \mathrm{~cm}$

nikon D70
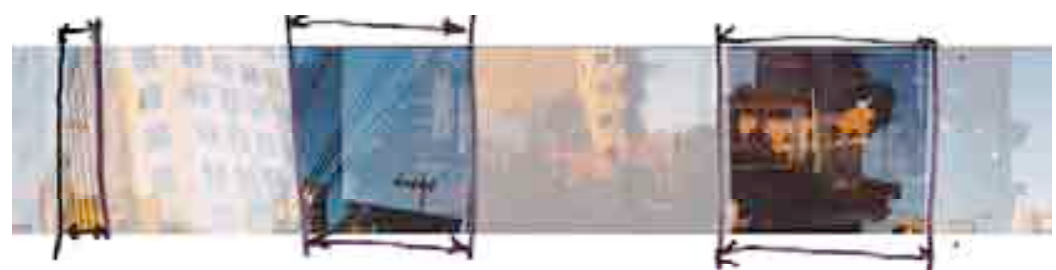

imagem

$40 \times 80 \mathrm{~cm}$

rolleiflex sI35

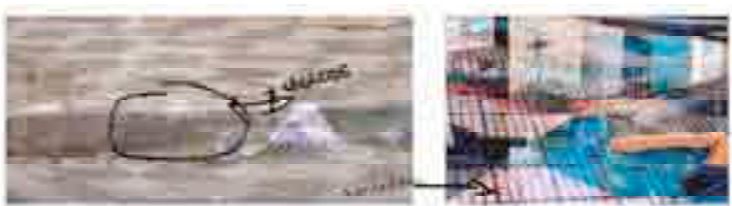

8.

9.
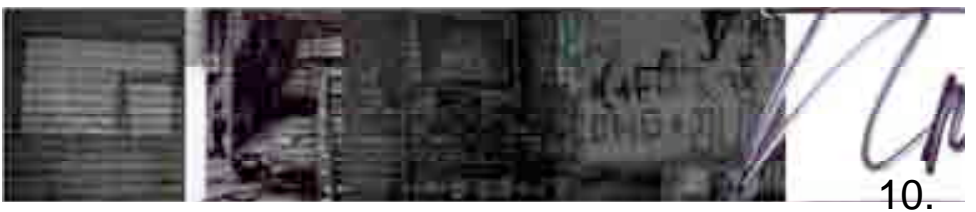

2003

$40 \times 20 \mathrm{~cm}$

rolleiflex sl35

2006

$50 \times 100 \mathrm{~cm}$

nikon D70

200

$40 \times 40 \mathrm{~cm}$

hasselblad

2003

$60 \times 40 \mathrm{~cm}$

rolleiflex sl35

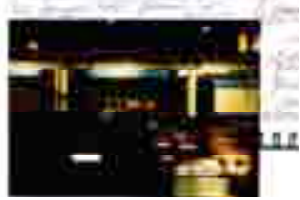

11.

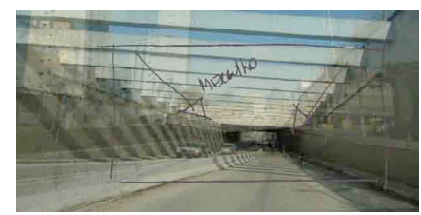

12.

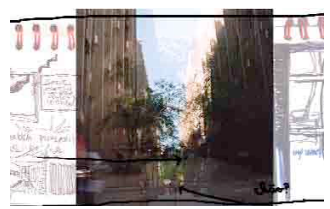

13.

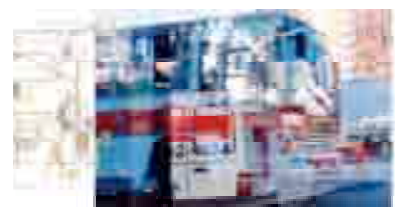

14. 
imagem

15.

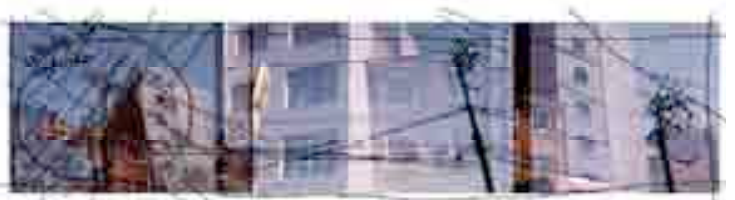

16.

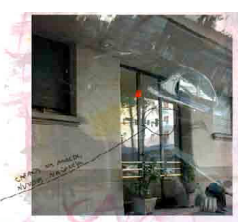

17.

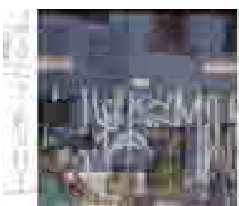

18.

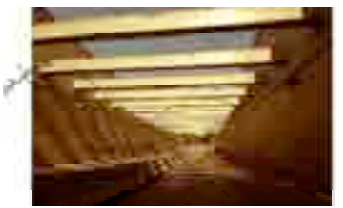

2006

$50 \times 100 \mathrm{~cm}$

nikon D70

2005

$80 \times 80 \mathrm{~cm}$

nikon D70

200

$80 \times 80 \mathrm{~cm}$

hasselblad

2005

$80 \times 640 \mathrm{~cm}$

nikon D70

2003

$135 \times 90 \mathrm{~cm}$

rolleiflex sl35

2003

$60 \times 40 \mathrm{~cm}$

rolleiflex sl35

20.

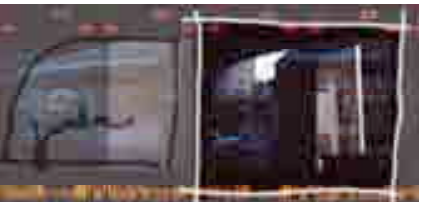

21.

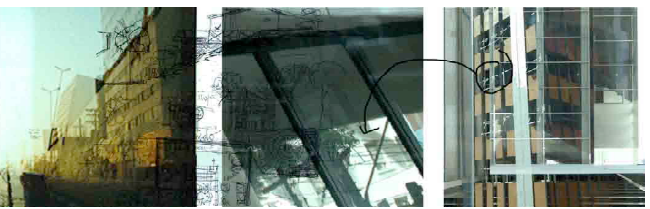

página

56

61

62

63

70

73

$2006 \quad 2005 \quad 2005$

$80 \times 80 \mathrm{~cm} \quad 80 \times 80 \mathrm{~cm} \quad 80 \times 6800 \mathrm{~cm}$

nikon D70 nikon D70 nikon D70 


ARGAN, Giulio Carlo. A história da arte com história da cidade.São Paulo: Martins Fontes, 1993.

AUMONT, Jacques. A Imagem. Campinas: Papirus, 2004.

BARTHES, Roland. A Câmara Clara. Rio de Janeiro: Nova Fronteira, 2003.

BENJAMIN, Walter. Magia e técnica, arte e política: ensaios sobre literatura e história da cultura.

São Paulo: Brasiliense,1994.

"A Obra de Arte na Época de sua Reprodutibilidade Técnica". In: LIMA, L. C.

(org.). Teoria da Cultura de Massa. Rio de Janeiro: Ed. Paz e Terra, 1978.

BERGER, John. Modos de Ver. Rio de Janeiro: Rocco,1999.

CALVINO, Ítalo As Cidades Invisíveis. São Paulo: Companhia das Letras,1999.

CATTANI, Icleia. "Arte Contemporânea: O Lugar da Pesquisa". In: Brites, Blanca, Tessler, Elida (org.). O meio como ponto zero - Metodologia da pesquisa em Artes Plásticas. Porto Alegre: Editora da UFRGS, 2002. pp. 35 - 50

COSTA, Helouise \& SILVA, Renato Rodrigues da. A Fotografia Moderna no Brasil. São Paulo: Cosac Naify, 2004.

COSTA, Lúcio. Registro de uma Vivência. São Paulo, Empresa das artes, 1995.

CRIMP, Douglas. On the Museum's Ruins. Mass.: MIT Press,1993.

DELEUZE, Gilles \& GUATTARI, Félix. O que é Filosofia? São Paulo: Editora 34, 1992.

DIDI-HUBERMAN, Georges. O que Vemos, O que nos Olha. São Paulo: Editora 34, 2005.

DUBOIS, Philippe. O Ato Fotográfico e Outros Ensaios. Campinas: Papirus, 2003.

Cinema, Vídeo, Godard. São Paulo: Cosac Naify, 2004.

FABRIS, Annateresa. Fragmentos Urbanos. São Paulo: Studio Nobel, 2000. 
FERRARA, Lucrecia D'alessio. Ver a Cidade: Cidade, Imagem, Leitura. São Paulo: Nobel, 1988.

FLUSSER,Vilém. Filosofia da Caixa Preta - Ensaios para uma Futura Filosofia da Fotografia. Rio de Janeiro: Relume Dumará, 2002.

GUATARRI, Felix. Caosmose - Um Novo Paradigma Estético. São Paulo: Editora 34, 1992.

KRAUSS, Rosalind E. The Originality of the Avant-garde and Other Modernist Myths. Mass.: MIT Press, 1988.

O Fotográfico. Barcelona: Gustavo Gili, 2002.

MACHADO, Arlindo. A Ilusão Especular -Introdução à Fotografia. São Paulo: Brasiliense/ Funarte, 1984.

Pré-cinemas e Pós Cinemas. Campinas: Papirus, 2002.

MEISTER, Sara Hermanson. Michel Wesely - Open Shutter. Nova lorque: MOMA, 2004.

MOTTA, Flávio. Textos Informes. São Paulo: FAU/USP, 1973.

MUNARI, Bruno Das Coisas Nascem Coisas. São Paulo: Martins Fontes, 1998.

MUSEUM LUDWIG DE COLÔNIA. A Fotografia do Século XX. Cologne:Taschen, 1988.

NOVAES, Adauto (org.). O Olhar. São Paulo: Companhia das Letras, 2003.

PEIXOTO, Nelson Brissac. Paisagens Urbanas. São Paulo: Senac/ Marca D'Água,1998.

PERFECT SQUARES SERIES. Man Ray. Londres: Grange Books, 2005.

RUIZ, Castor Bartolomé. Os Paradoxos do Imaginário. São Leopoldo: Unisinos, 2004.

SANTOS, Alexandre. "Da cidade como resposta à cidade como pergunta: a fotografia como dispositivo de representação/apresentação do espaço urbano". In: \& SANTOS, Maria Ivone dos. (org.). A Fotografia nos Processos Artísticos Contemporâneos. Porto Alegre: Unidade Editorial da Secretaria Municipal de Cultura/ Editora da UFRGS, 2004. pp. 38 - 60.

SCHAPIRO, Meyer. Impressionismo: Reflexões e Percepções. São Paulo: Cosac \& Naify, 2002 
SNOW, C.P. As Duas Culturas e Uma Segunda Leitura. São Paulo: Edusp, 1995.

SONTAG, Susan. Sobre Fotografia. São Paulo: Companhia das Letras, 2004.

VIRILIO, Paul. O Espaço Crítico e as Perspectivas do Tempo Real. São Paulo: Editora 34, 1999.

ZEVI, Bruno. Saber Ver a Arquitetura. Lisboa: Arcádia, 1966.

\section{Outros Livros}

ANDRADE, Carlos Drummond de. Sentimento do Mundo. Rio de Janeiro: Record, 1999.

BANDEIRA, Manoel. Estrela da Vida Inteira. Rio de Janeiro: Nova fronteira, 1995.

BAUDELAIRE, Charles, As Flores do Mal . Rio de Janeiro: Nova Fronteira, 2004.

CARROL , Lewis Aventuras de Alice. São Paulo: Summus, 1980.

MARQUES, Gabriel Garcia. Viver para contar. São Paulo/ Rio de Janeiro: Editora Record, 2003.

PESSOA, Fernando. Obras em Prosa. Rio de Janeiro: Nova Aguiar, 1986. Obra poética. Rio de Janeiro: Nova Aguiar,1983.

RILKE, Rainer Maria, Cartas a um jovem poeta. São Paulo: Globo, 1989.

ROSA, João Guimarães. Primeiras Estórias. Rio de Janeiro: ed. Nova fronteira. 2001.

SARAMAGO, José. Ensaio Sobre a Cegueira. São Paulo: Cia das Letras, 1996.

WATTERSON, Bill. Os dez anos de Calvin e Haroldo vol 2. São Paulo: Best Expressão Social e Editora Ltda., 1995. 


\section{Periódicos}

BUREN, Daniel. "The Function of the Studio". In: October, v. 10, 1979. pp. 51-58.

FABRIS, Annateresa. "Redefinindo o conceito de imagem". In Revista Brasileira de História. São Paulo, v.18, no 35,1998 . pp. 217-224.

FERRARA, L. D. "As Mascaras da Cidade". In: Revista da USP, v. 05, 1990. pp. 3-10.

ROUANET, Sérgio Paulo . "É a cidade que habita os homens ou são eles que moram nela?" In: Revista USP, n. 15, set-out-nov. 1992. pp. 50 - 75.

\section{Catálogos}

18 BIENAL Internacional de São Paulo : catalogo geral. São Paulo : Fundação Bienal de São Paulo, 1985. (Catálogo de exposição)

ARTE/Cidade. São Paulo : Marca D'agua, 1994. (Catálogo de exposição)

SANTOS, Laymert Garcia dos. "Configurações". In: BUUSSO, V. D. (cur.) Rede de Tensão. São Paulo: Imprensa Oficial do Estado/ Paço das Artes, 29/05 a 19/08 de 2001. pp. 17-24. (catálogo de exposição)

\section{$\underline{\text { Consulta aos Sites }}$}

BONDER, Nilton. Milênio e Shabat. Disponível em:

<http://www.cjb.org.br/khokhma/shabat/shabat_mil.htm>. Acesso em: 25 out. 2006.

CALLIGARIS, Contardo. Av. Faria Lima, Berlim Leste: Graças a uma nova lei da Prefeitura de São Paulo, logo viveremos felizes em Berlim Leste. Folha de São Paulo - Ilustrada 05/10/2006. Disponível em: <http://www1.folha.uol.com.br/fsp/ilustrad/fq0510200628.htm>. Acesso em: 25 out. 2006.

FABRIS, Annateresa. Redefinindo o conceito de imagem. Disponível em: <http://www.scielo.br/php?script=sci_arttext\&pid=SO102-01881998000100010\&lng=en\&nrm=iso.ISSN 0102-188>. Acesso em: 25 out. 2006. 
MACHADO, Arlindo. A Fotografia como Expressão do Conceito. Disponível em: <www.studium.iar.unicamp.br>. Acesso em: 25 out. 2006.

Filme

CORRA Lola Corra. Direção de Tom Tykwer. São Paulo: Columbia TriStar Films distribuidora, 1998. 1 DVD (81 min): DVD, son., Color., Legendado. Port.

\section{Músicas}

ALENCAR, Edson/ MATHEUS, Hélio. Comunicação. In: Em Pleno Verão, Philips, 1970 (Interpretação de Elis Regina).

BOSCO, João/ BLANC, Aldir. Transversal do Tempo. In: Elis, Phonogram, 1977. (Interpretação de Elis Regina).

CAETANO Veloso. Peter Gast. In: Uns, Polygram, 1983.

Se Essa Rua. In: Meu Tio Matou um Cara, Universal, 2004. (interpretação de Rappin'Hood e Luciana Mello).

Você Não Entende Nada. In: Caetano e Chico - juntos e ao vivo. Polygram, 1972. 

ficha técnica e cronologia das obras 



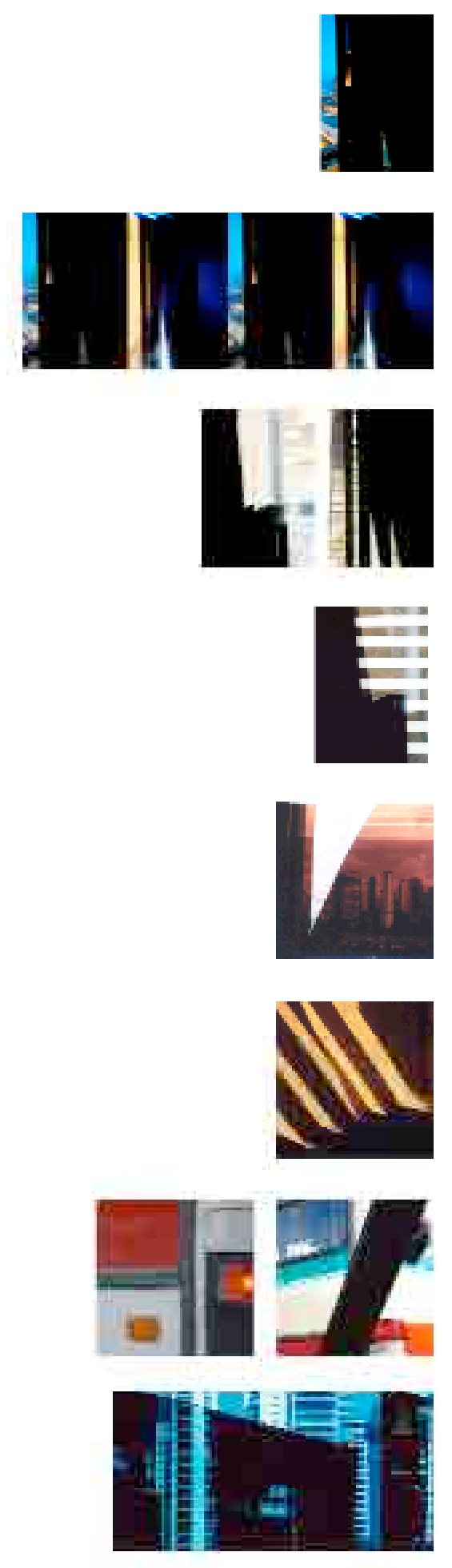

atrás da cortina preta 1 2002

$135 \times 90 \mathrm{~cm}$

olympus IS-50

atrás da cortina preta 1/2/3/4 2002

4 imagens $135 \times 90 \mathrm{~cm}$

olympus IS-50

atrás da cortina preta 26/17 2002

2 Imagens $135 \times 90 \mathrm{~cm}$

alympus IS-50

atrás da cortina preta 21

2002

$135 \times 90 \mathrm{~cm}$

olympus IS-50

sem título

2002

$15 \times 15 \mathrm{~cm}$

hasselblad

sem titulo

2002

$15 \times 15 \mathrm{~cm}$

hassciblad

sem titulo

2002

2 imagens $15 \times 15 \mathrm{~cm}$

hasselblad

sem título

2002

$30 \times 15 \mathrm{~cm}$

olympus IS-50 


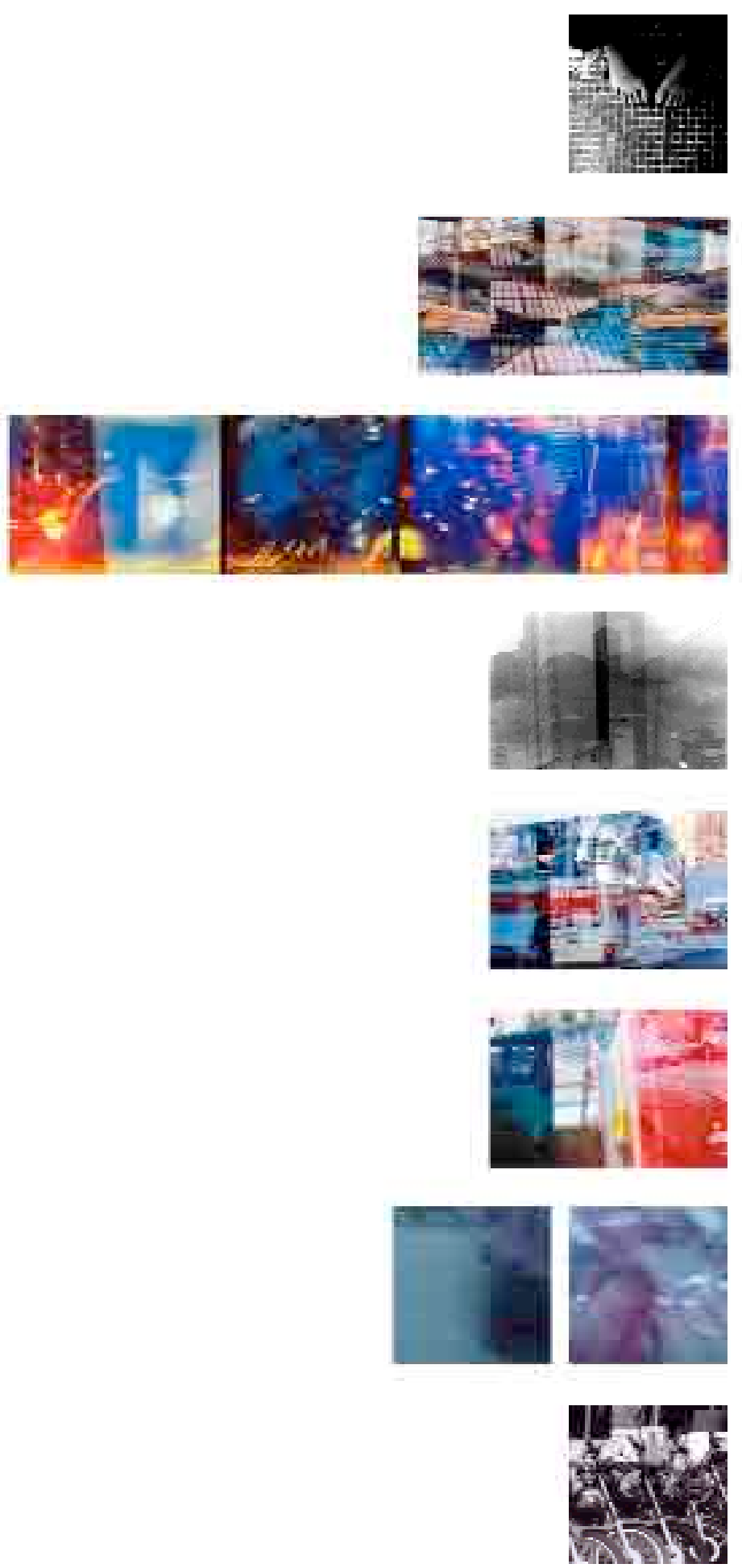

sem titulo

2003

$20 \times 20 \mathrm{~cm}$

hasselblad

sp450

2003

$40 \times 80 \mathrm{~cm}$

rolleiflex

sp 450.2

2003

$40 \times 136 \mathrm{~cm}$

rolleiflex

sem titulo

2003

$20 \times 30 \mathrm{~cm}$

rolleiflex

sem titulo

2003

$40 \times 60 \mathrm{~cm}$

rolleifiex

sem titulo

2003

$40 \times 60 \mathrm{~cm}$

rolleiflex

sem titulo

2003

2 imragens $20 \times 20 \mathrm{~cm}$

sony cybershot

sem fítulo

2003

$40 \times 40$

sony cybershot 


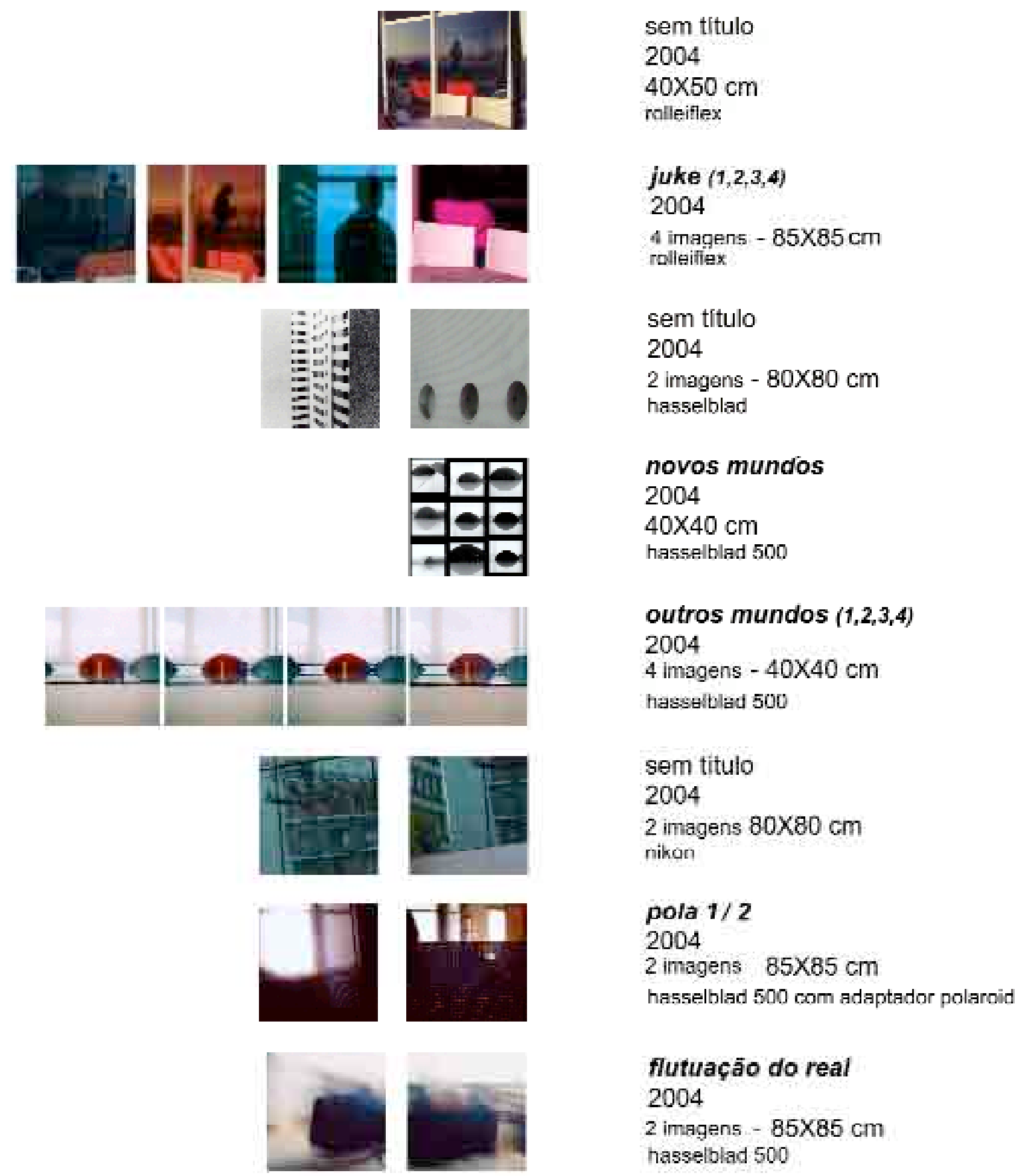



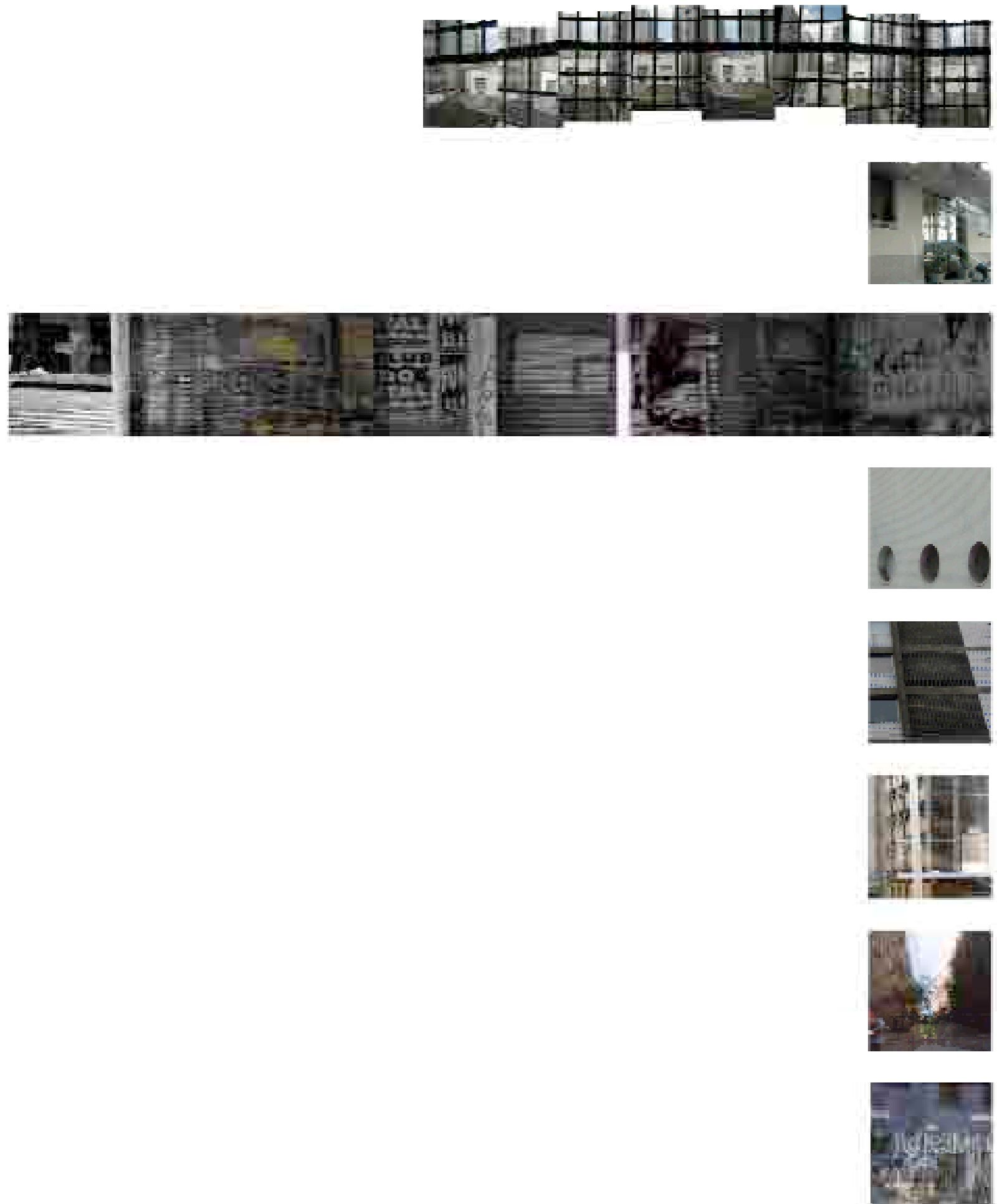

sem título

2005

$80 \times 370 \mathrm{~cm}$

nikonD70

sem título

2005

$80 \times 80 \mathrm{~cm}$

nikon D70

sem título

2005

$80 \times 640 \mathrm{~cm}$

nikon D70

sem título

2004

$80 \times 80$

hasselblad 500

sem título

2005

$80 \times 80 \mathrm{~cm}$

nikon D70

sem titulo

2005

$80 \times 80 \mathrm{~cm}$

nikon D70

sem títula

2005

$80 \times 80 \mathrm{~cm}$

hasselblad

sem titulo

2005

$80 \times 80 \mathrm{~cm}$

rolleiflex s! 36 


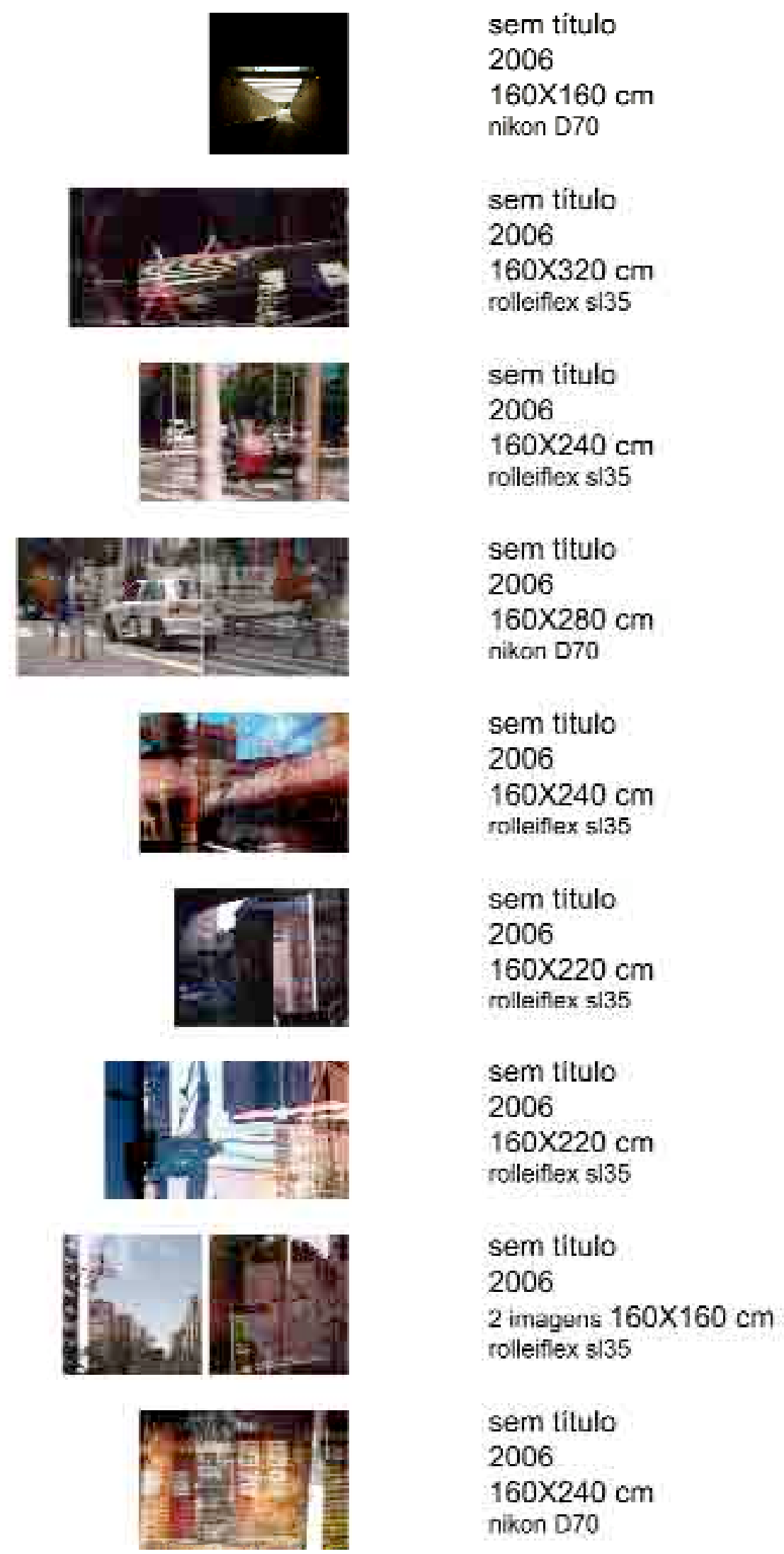






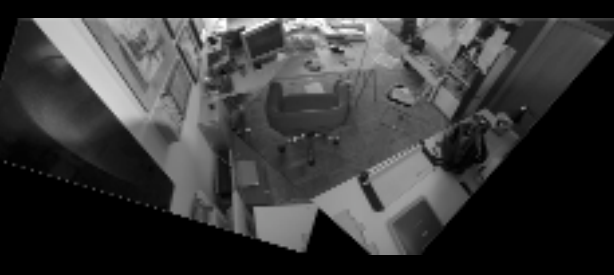

este livro tem projeto gráfco de

Vera Pilnik Sanovicz, revisão

ortográfica de Márcia Ungaretti e

ortográfica de Márcia Ungaretti e

1IImpressão em papel Couché $150 \mathrm{~g}$

2006 




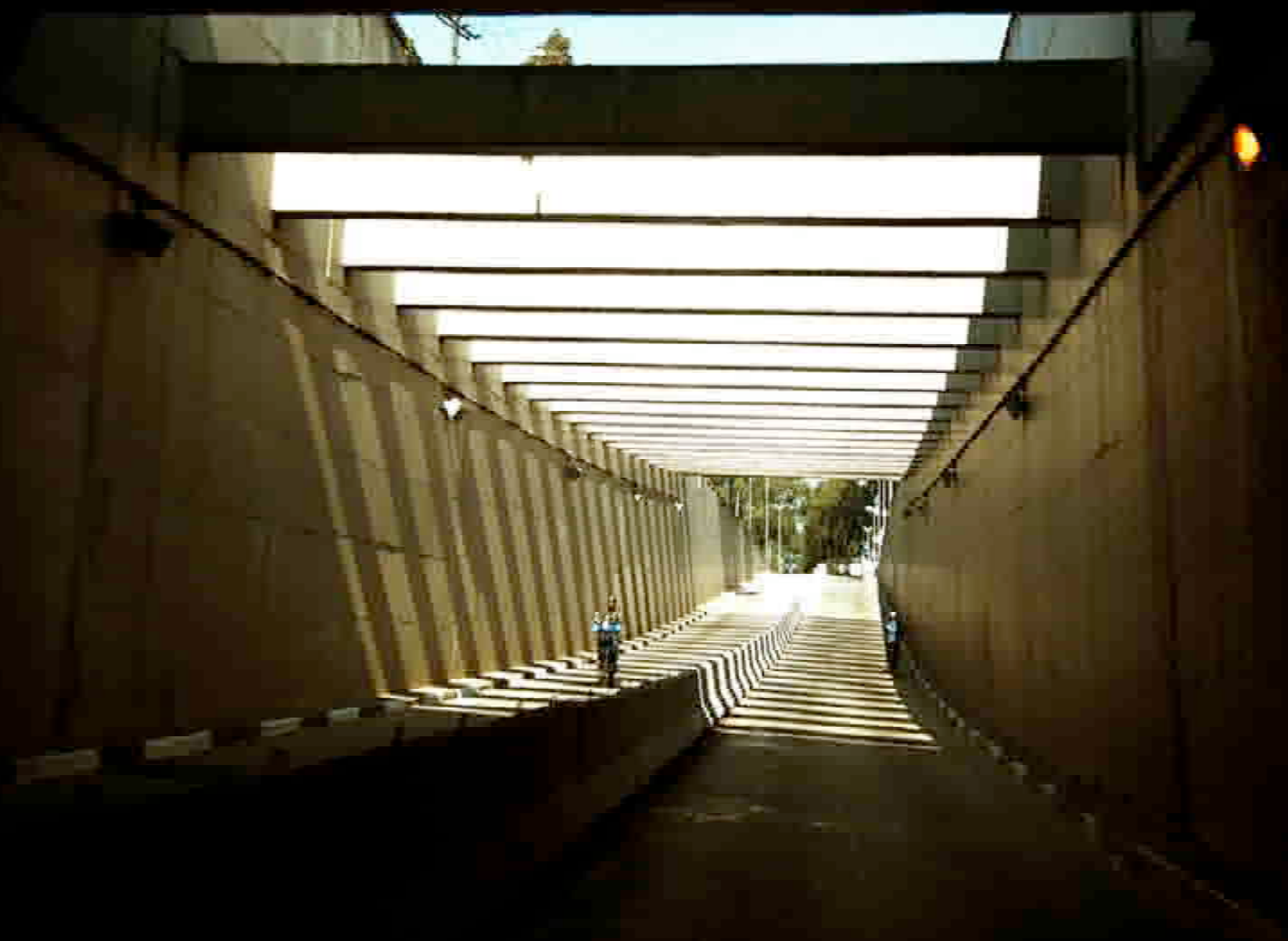



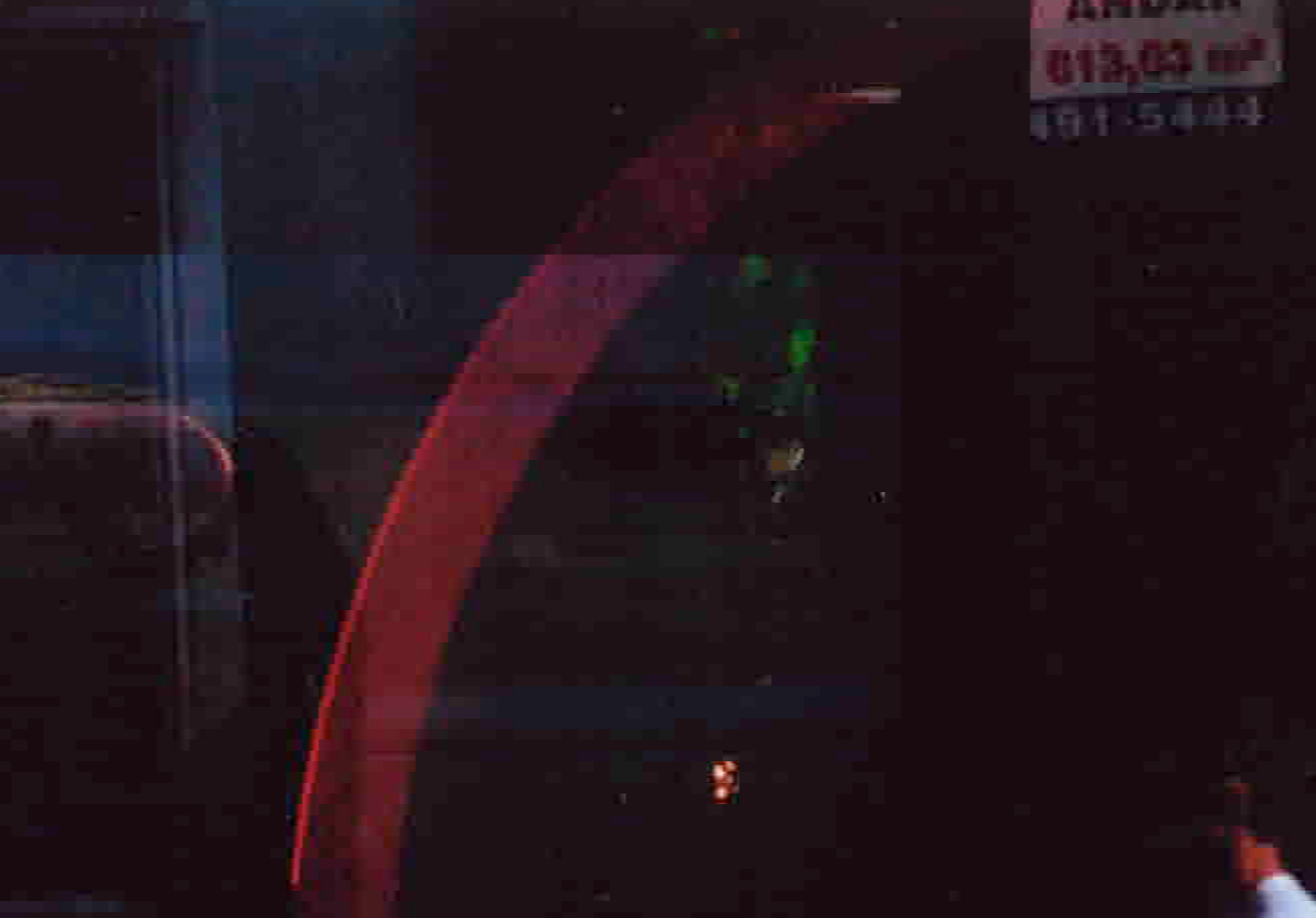

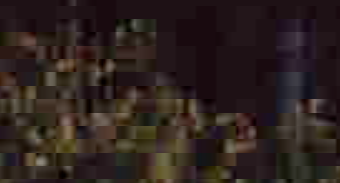

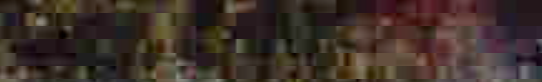

was

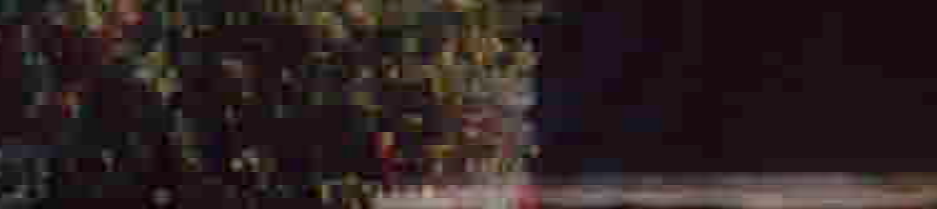

Pativg

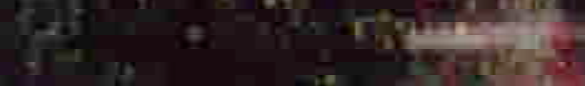

$x$ n nithing

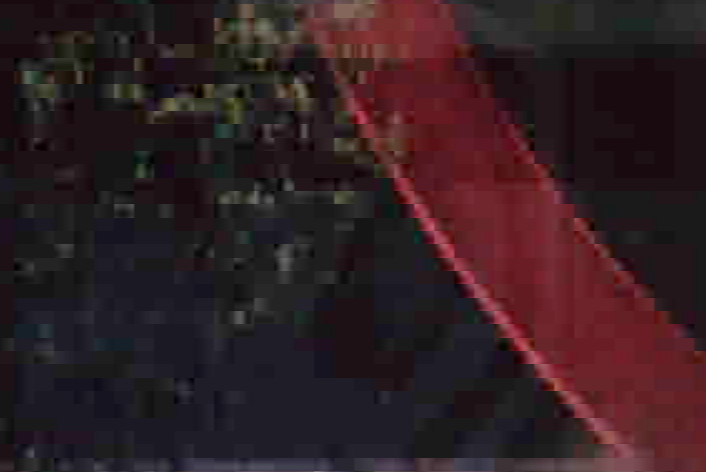

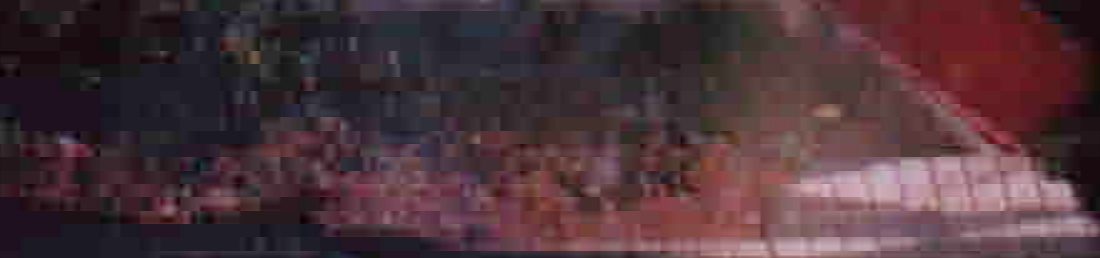

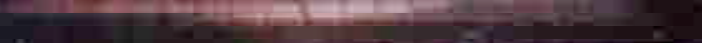

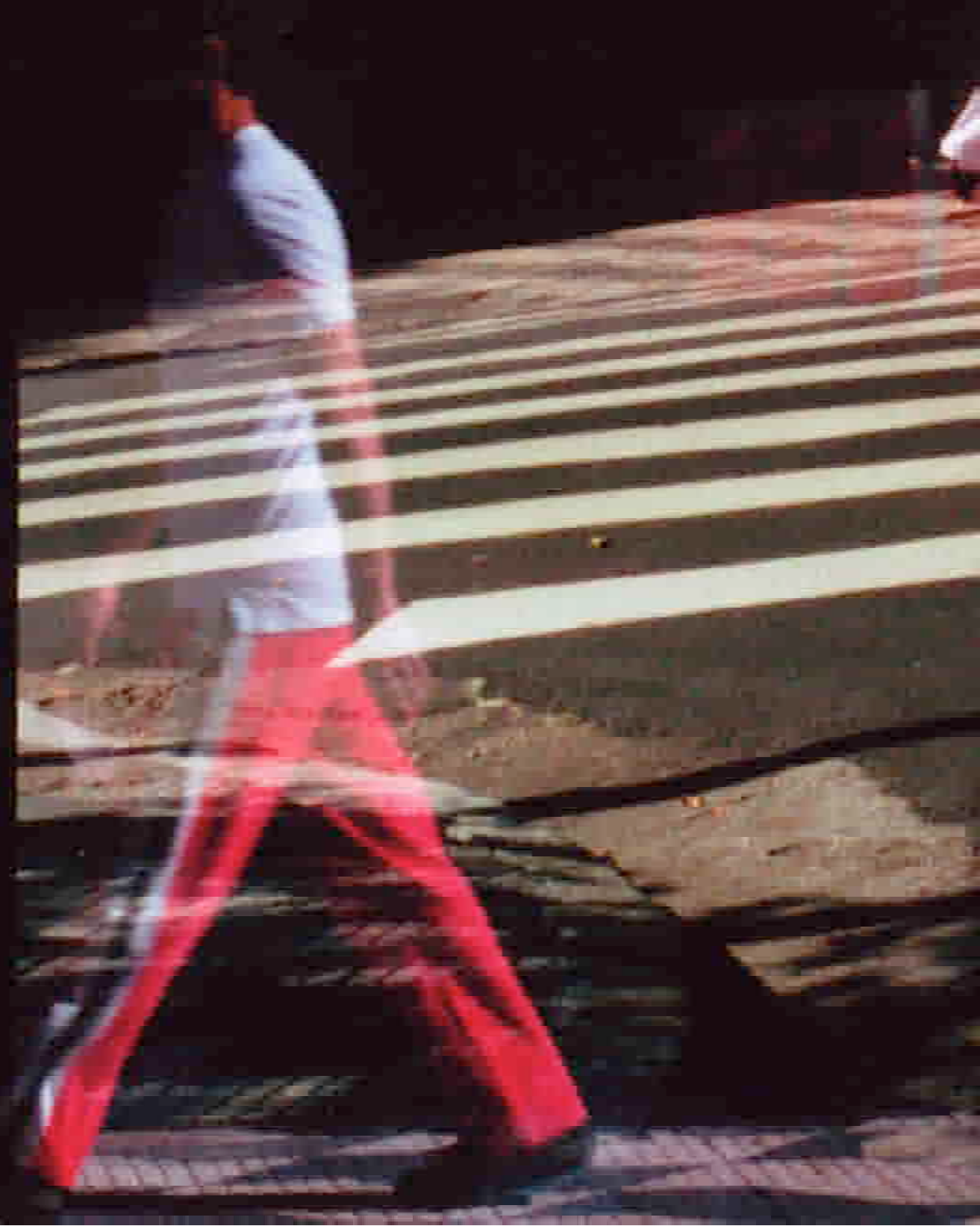




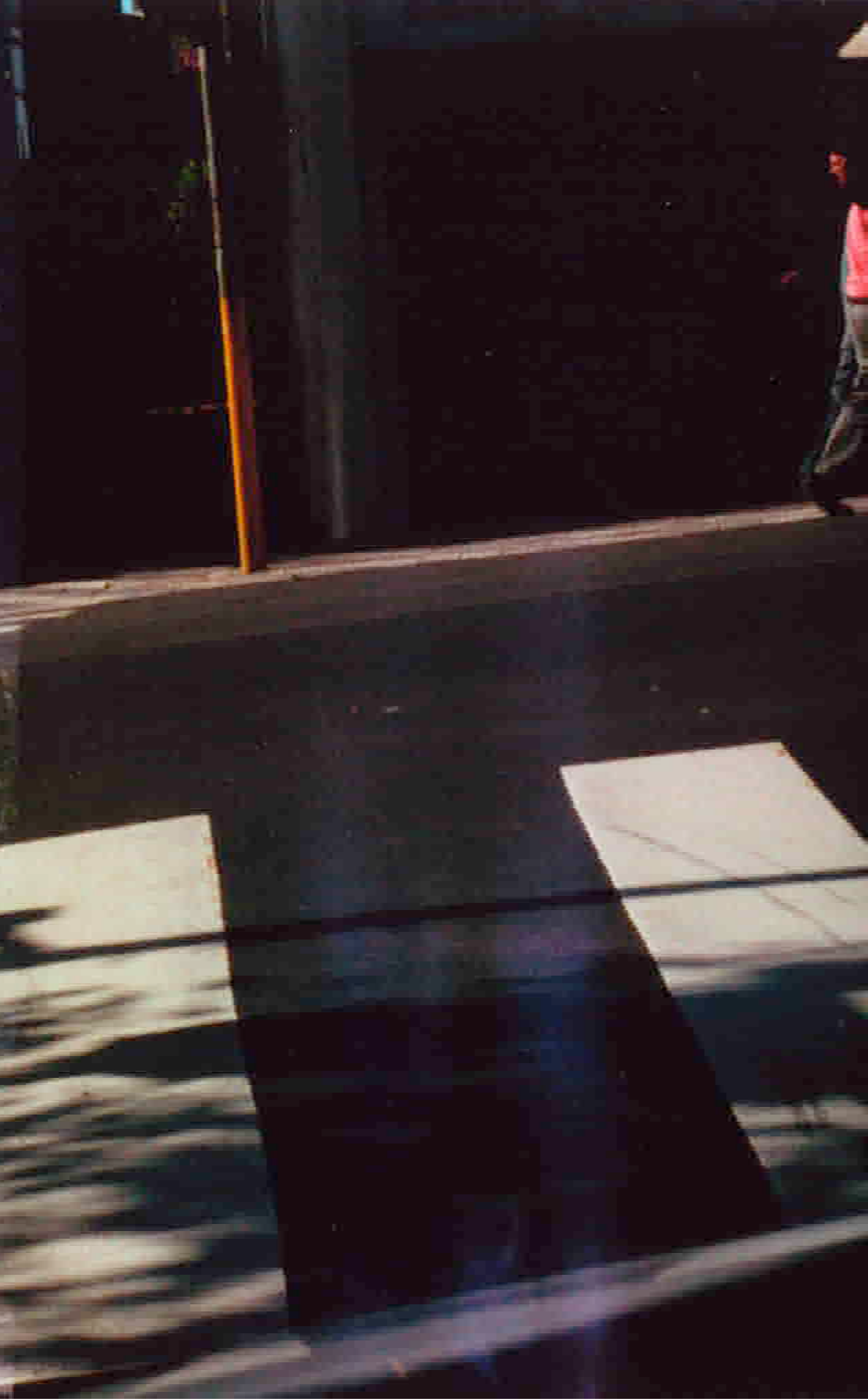




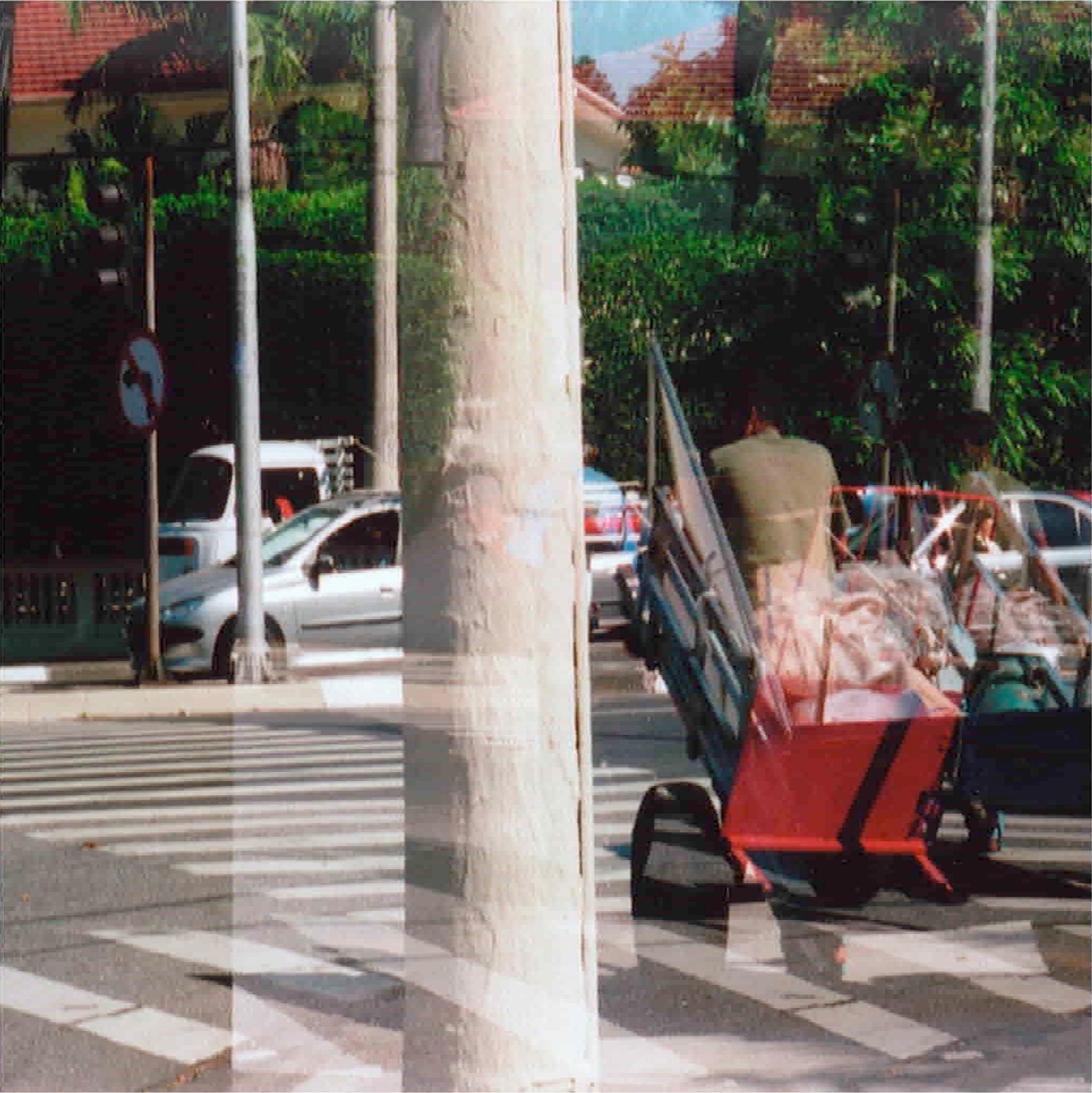




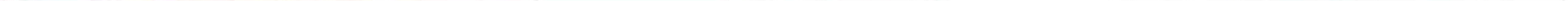




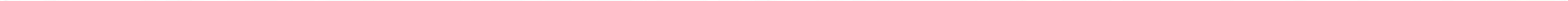




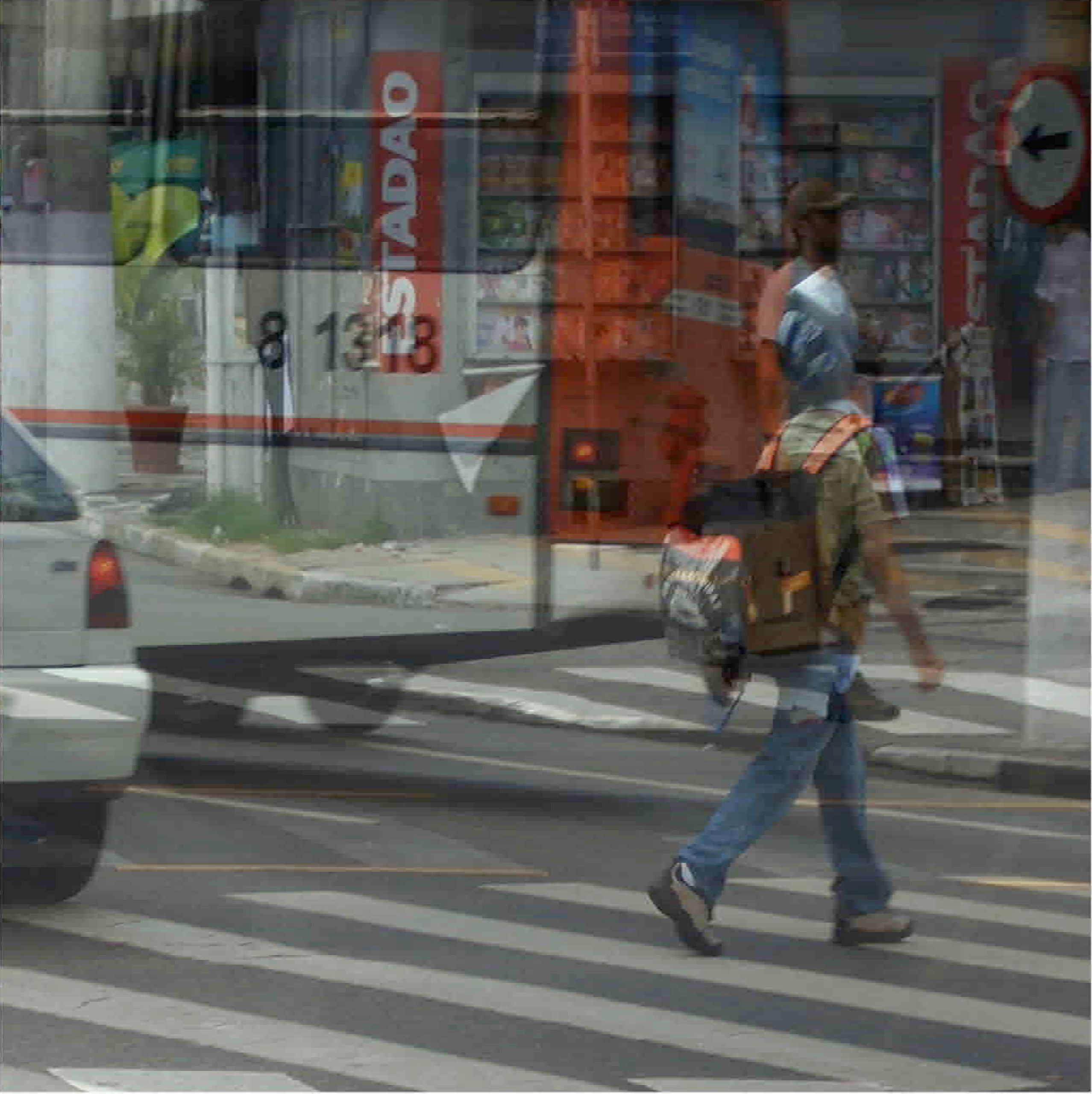




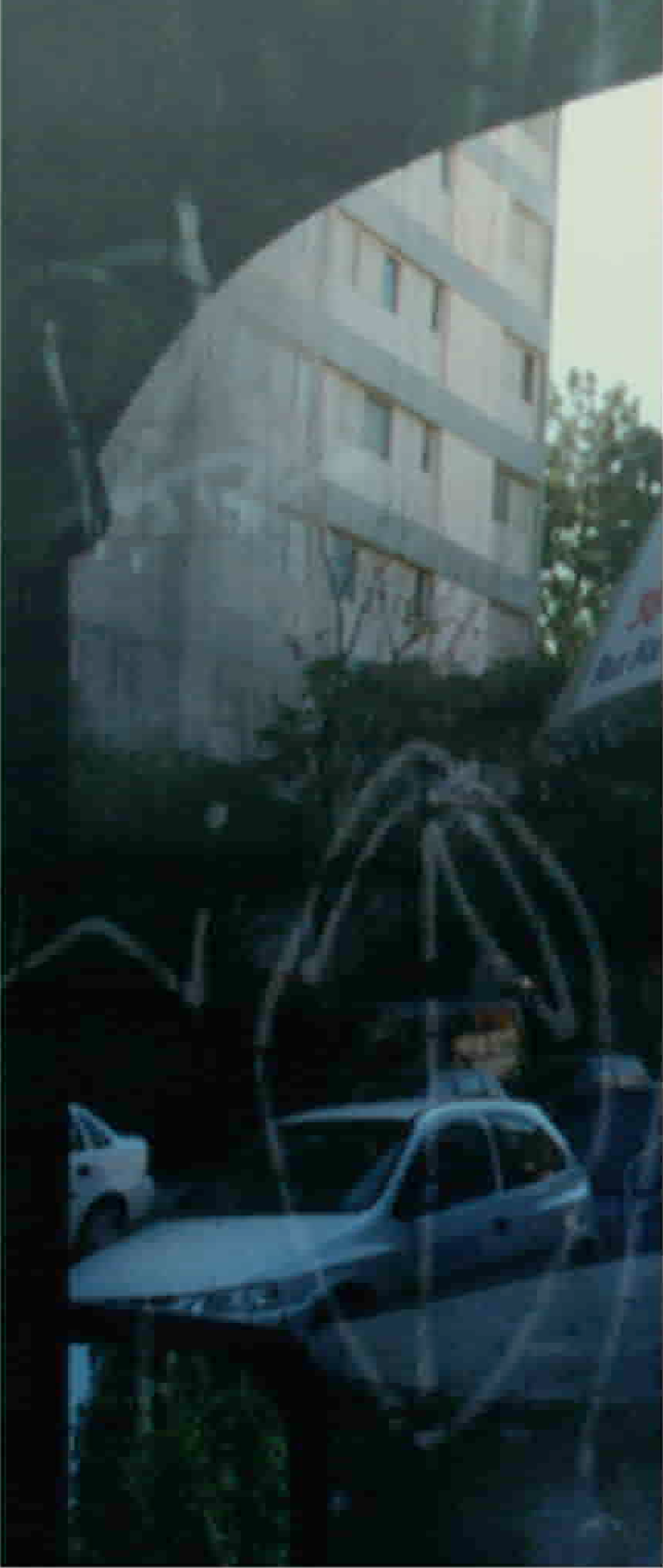




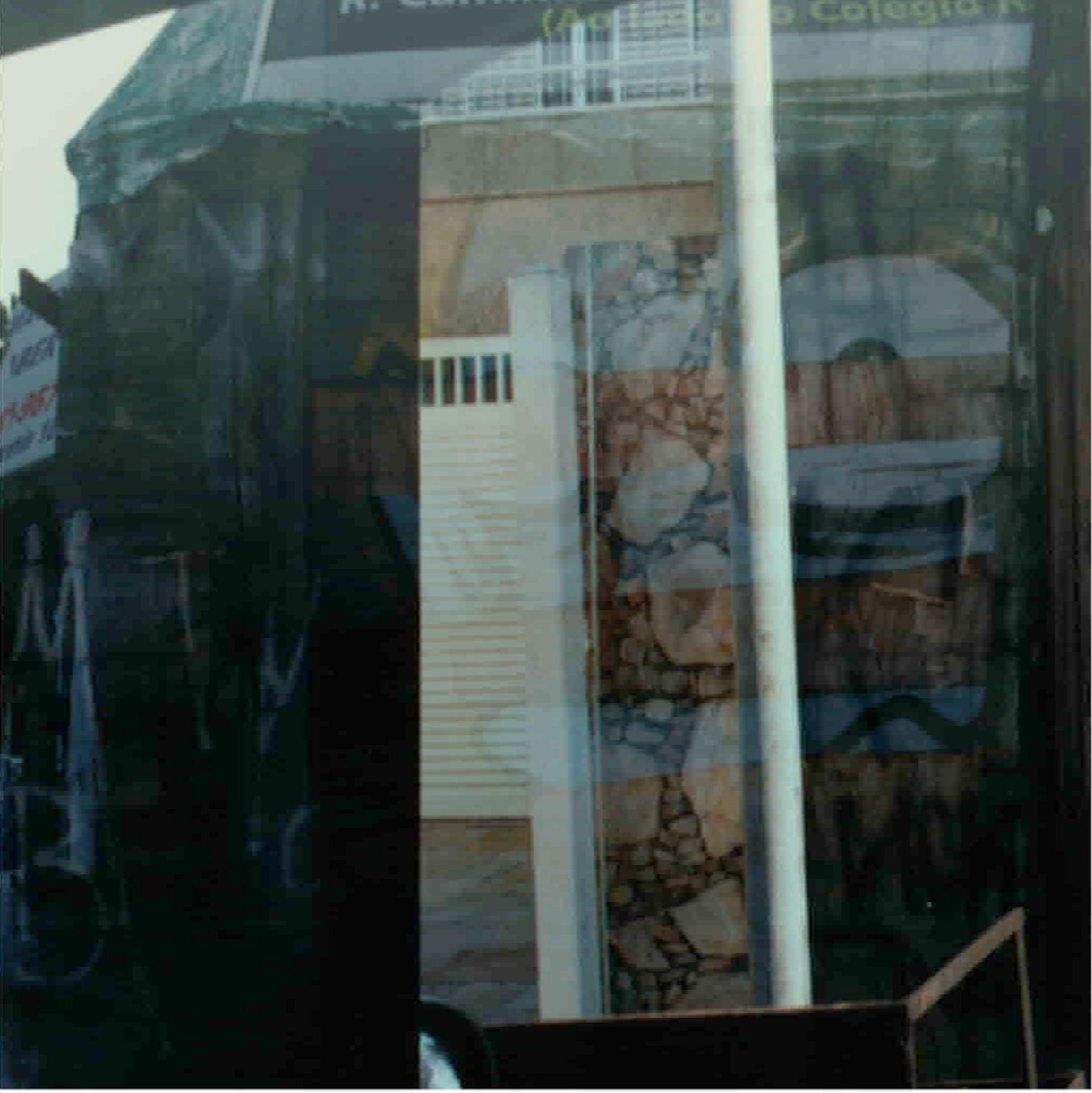




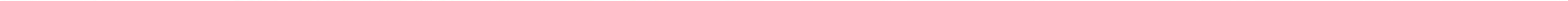




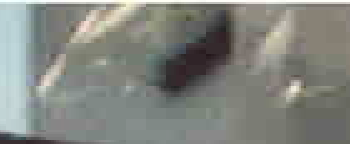

$-12$ 


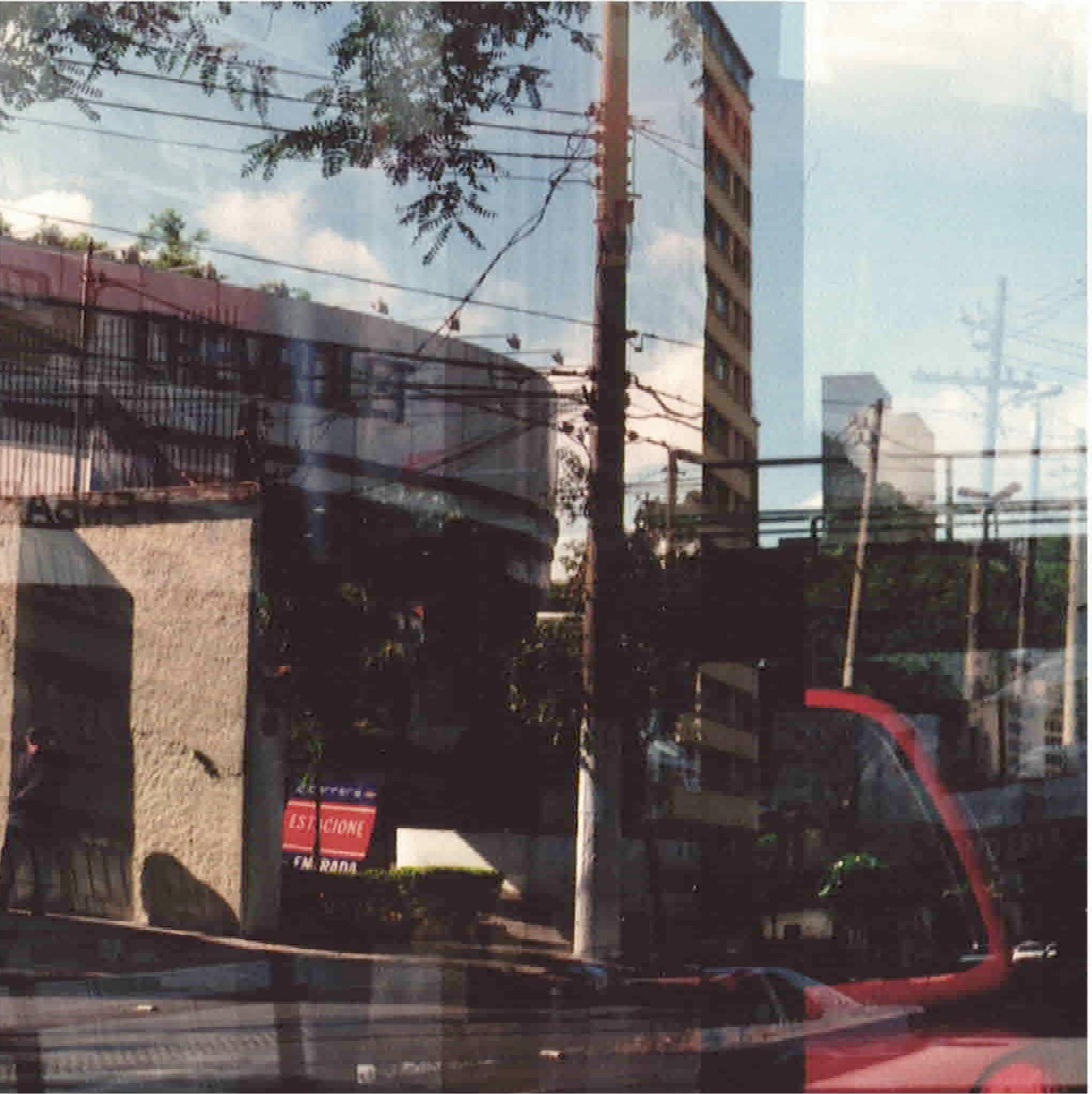





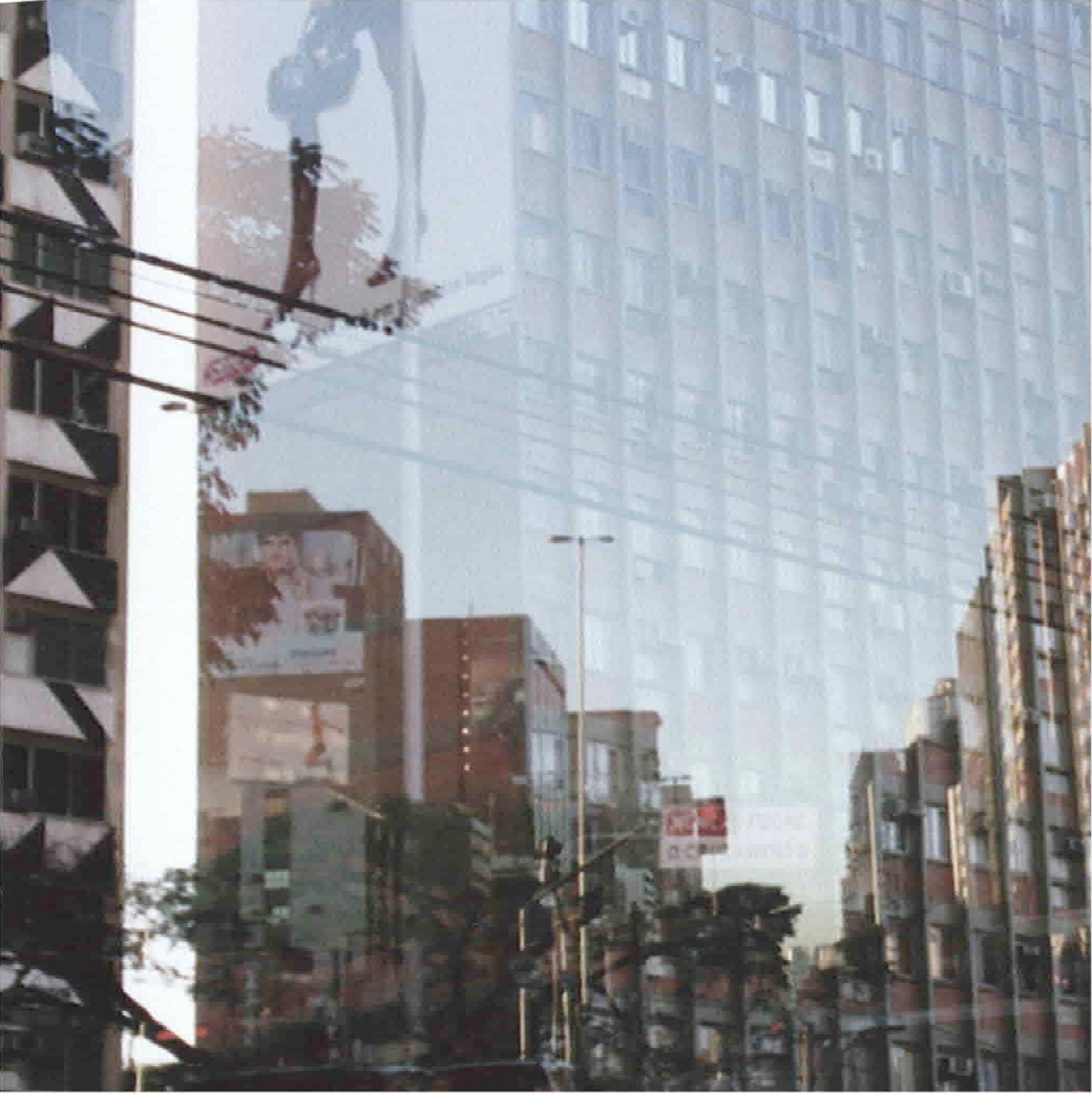




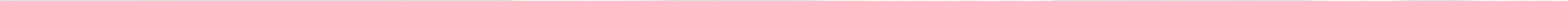




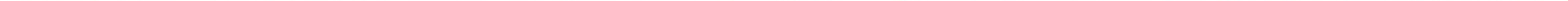




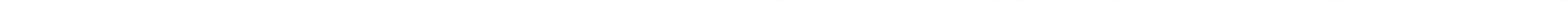





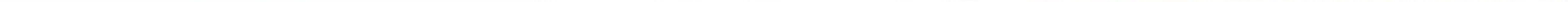






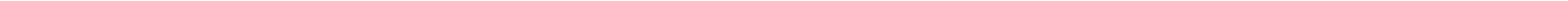




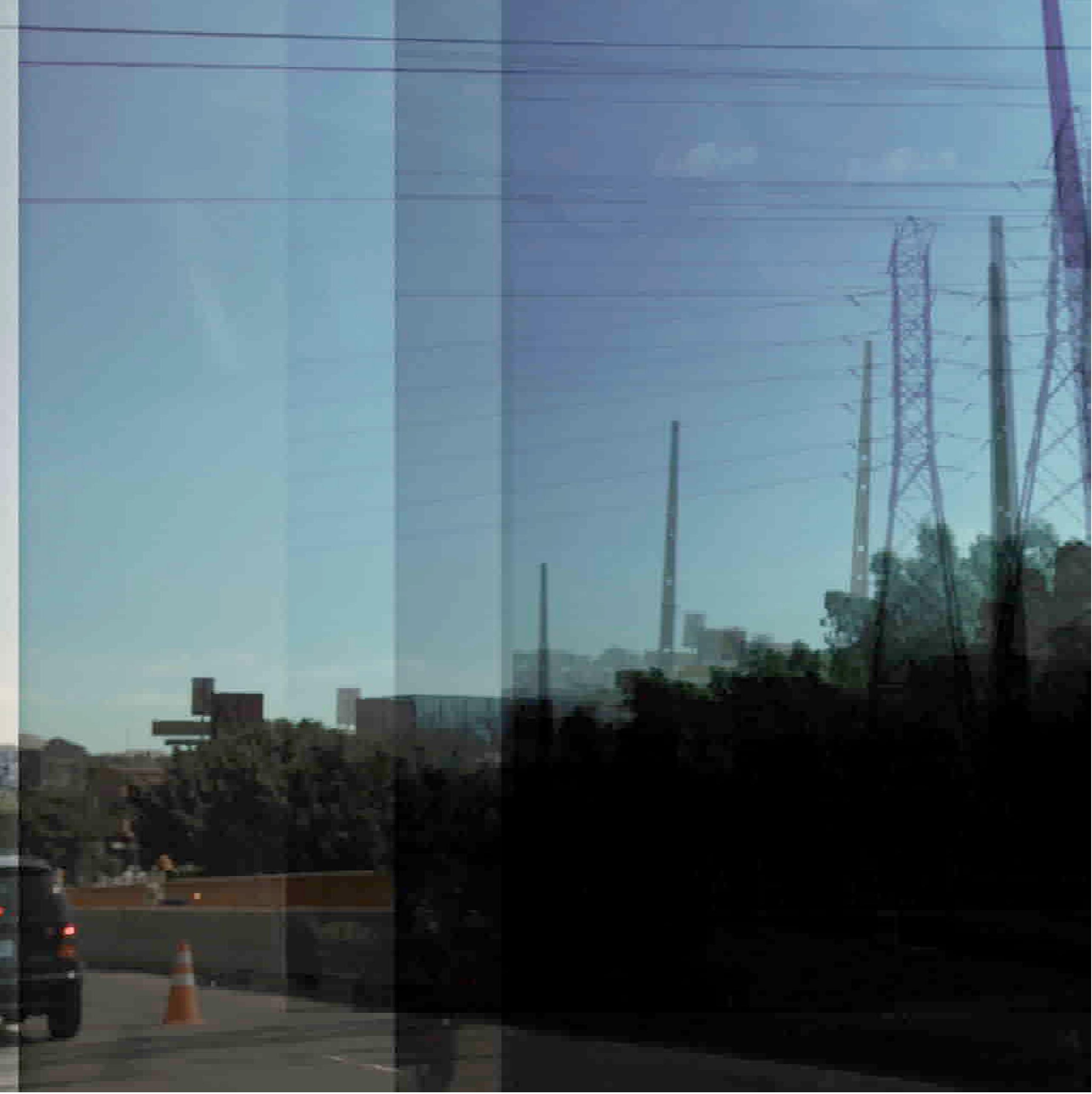





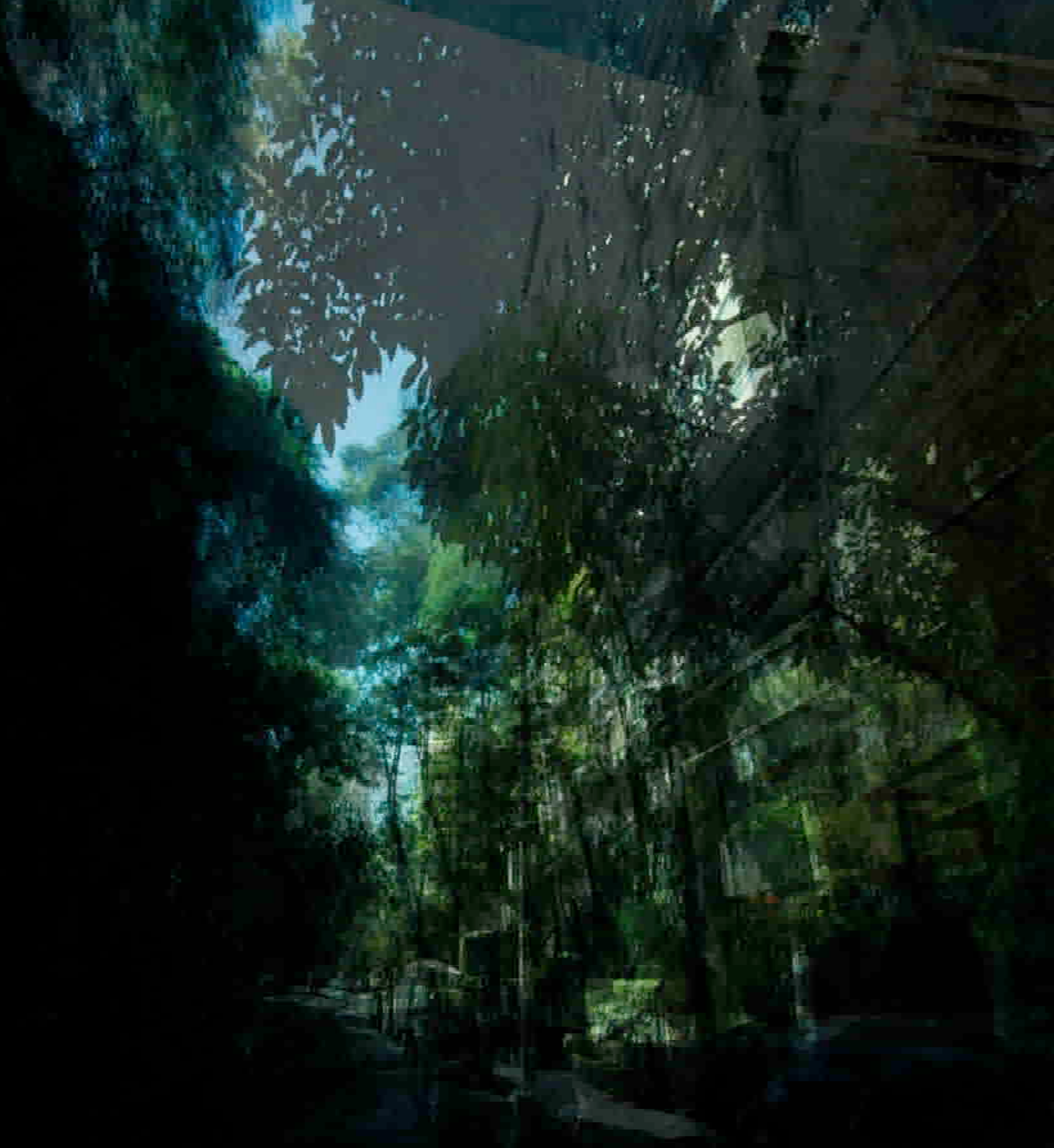




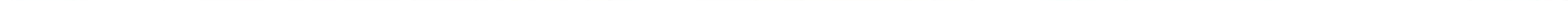




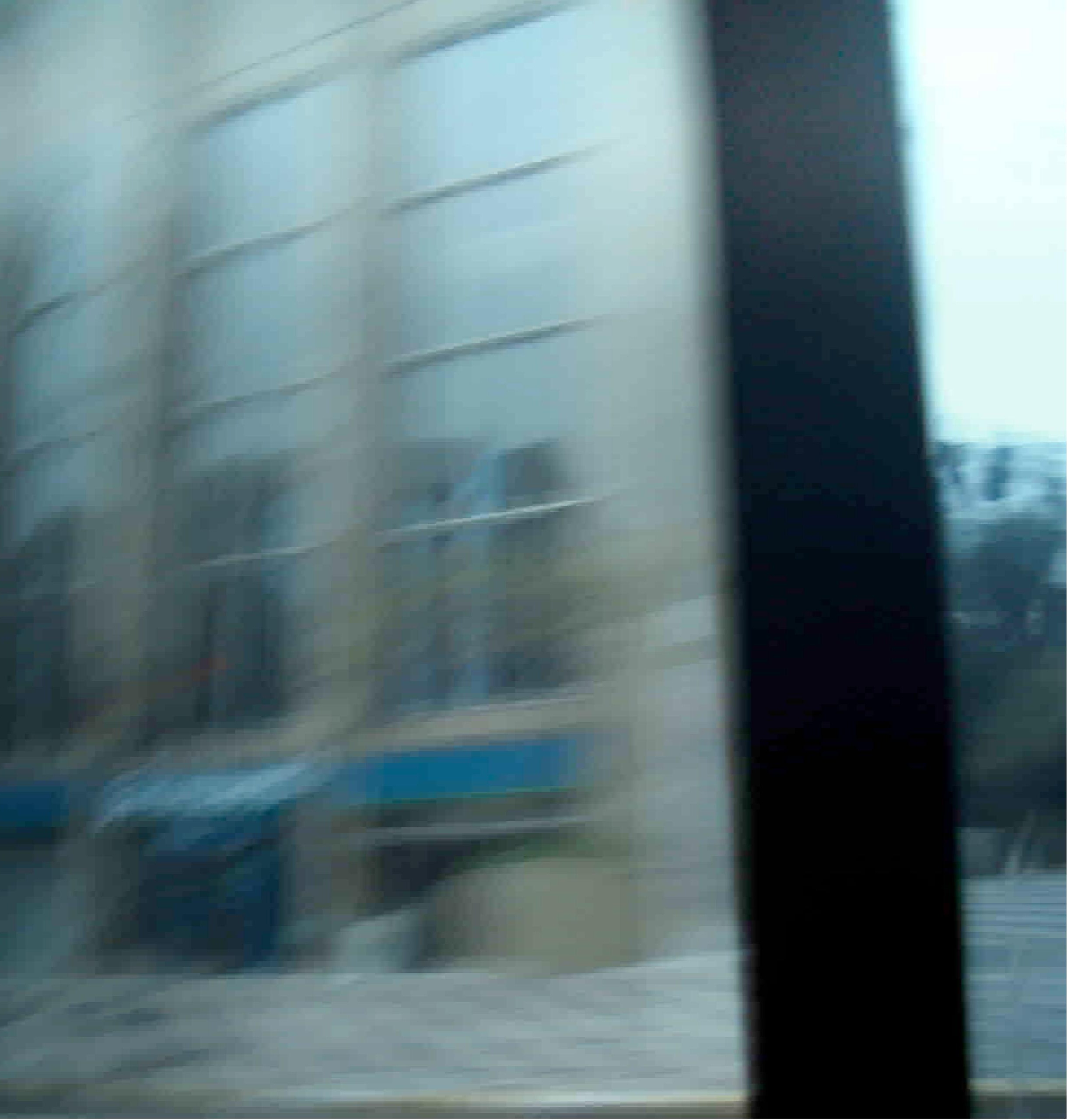




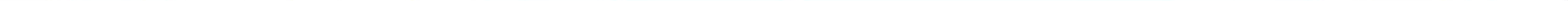





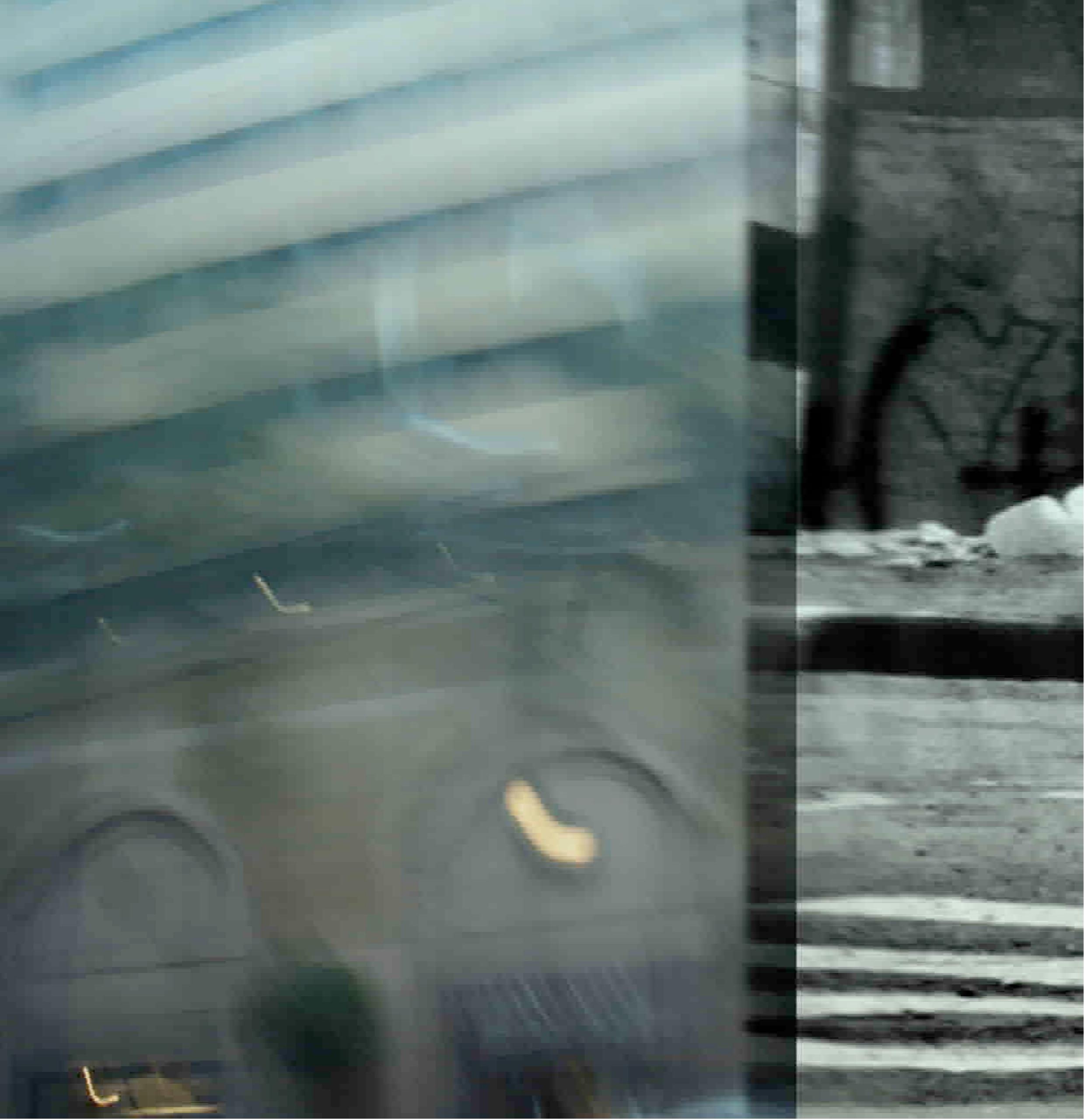




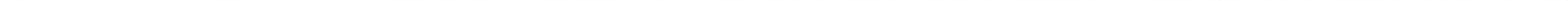



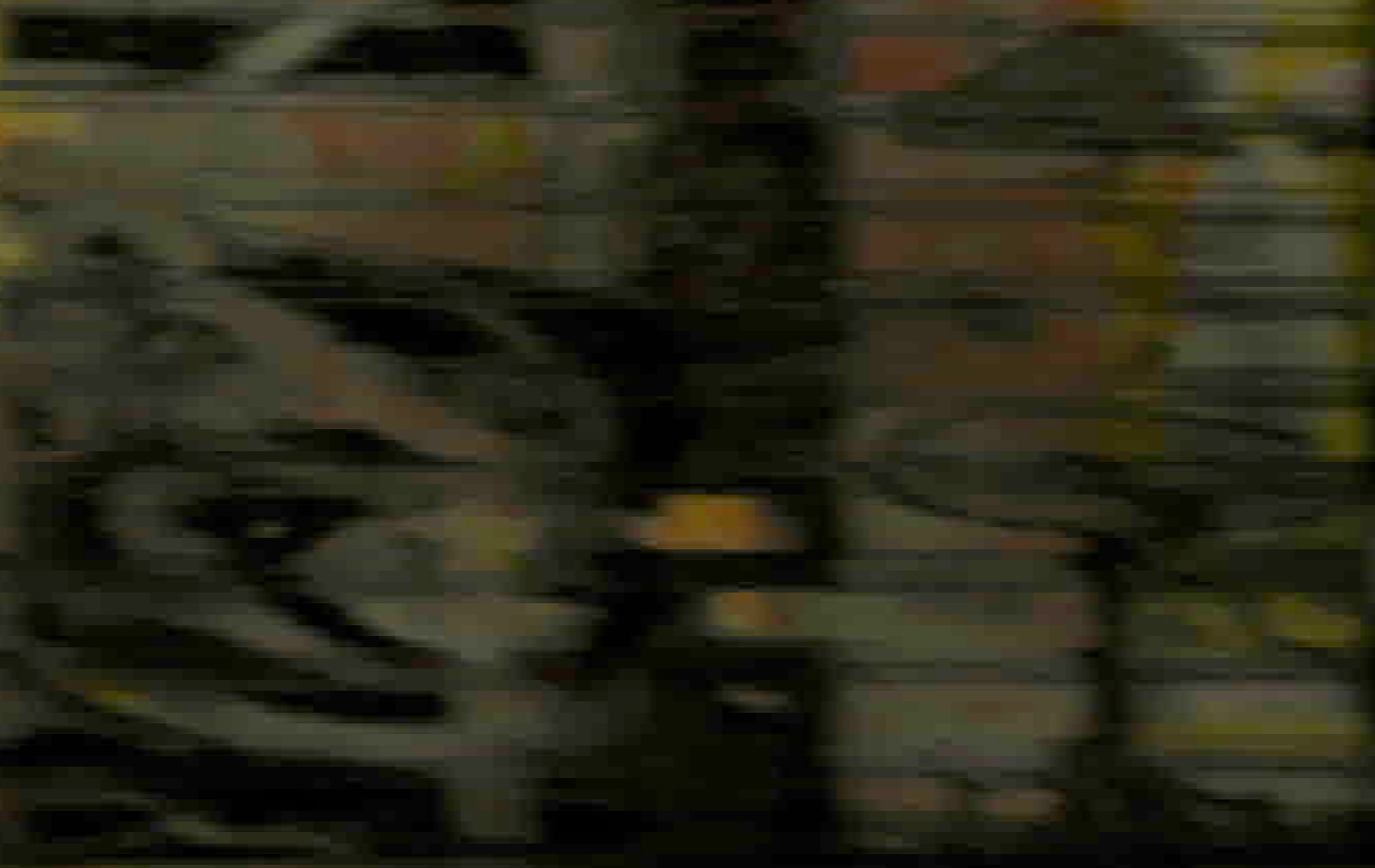

$+7$
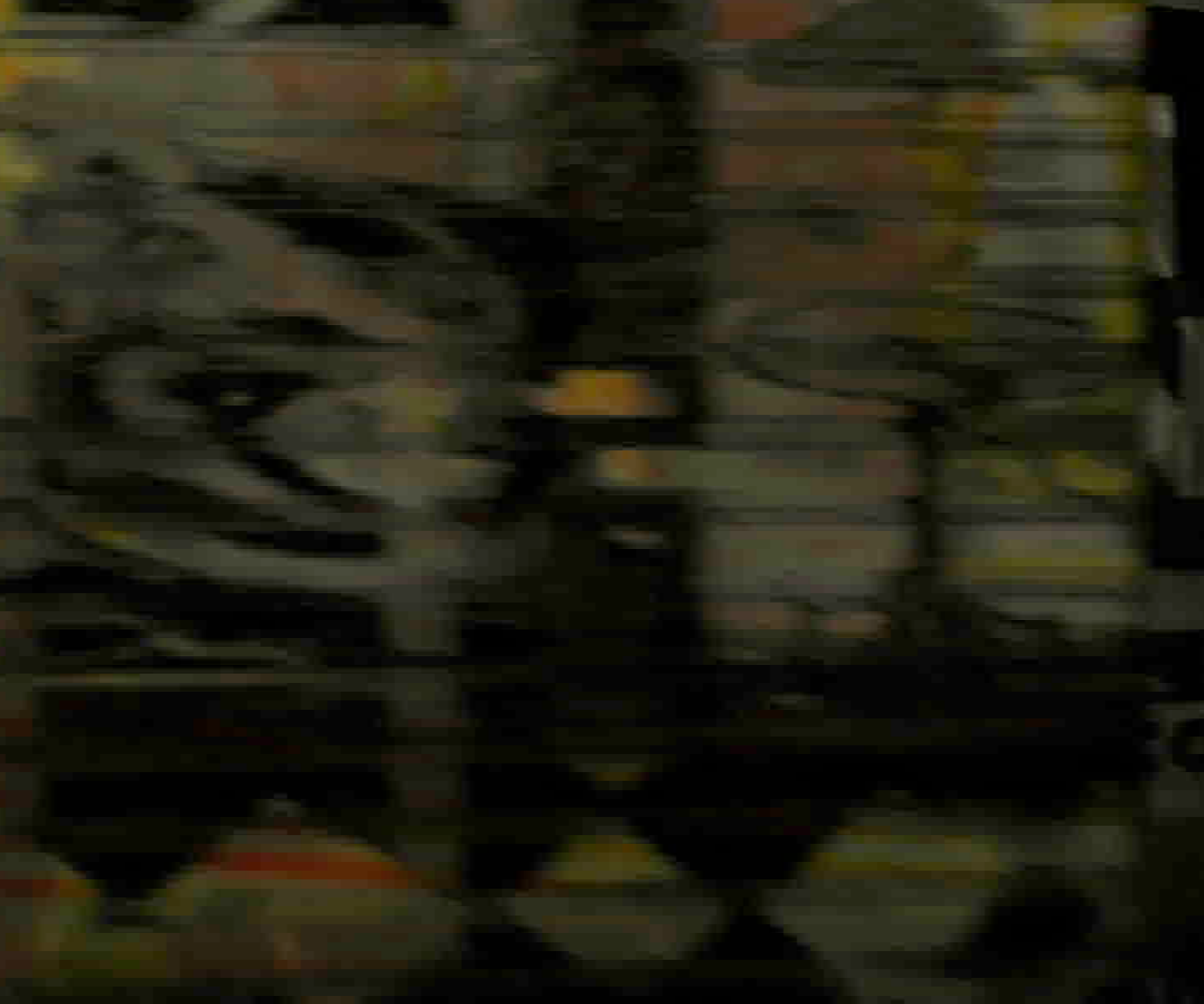

$2+3$

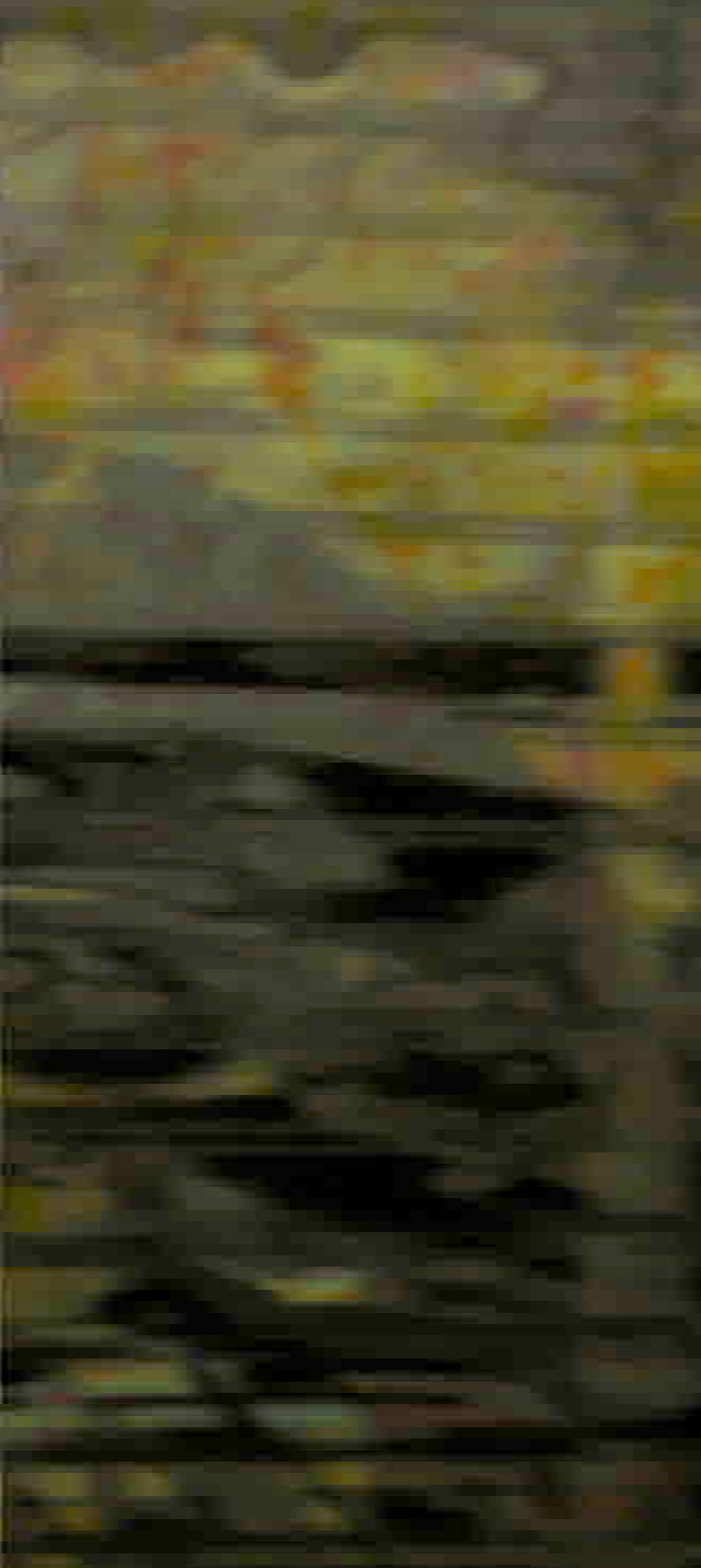



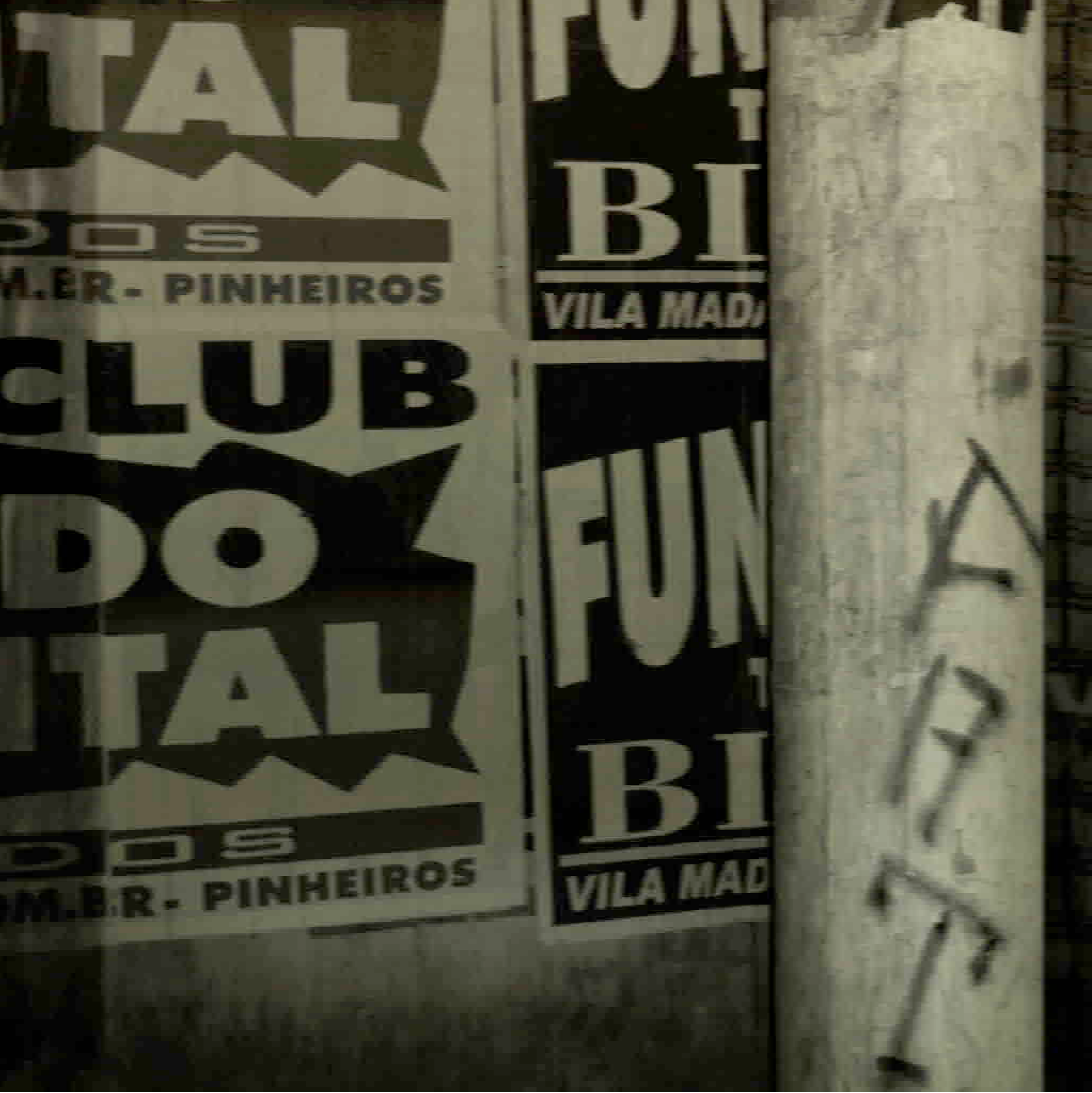


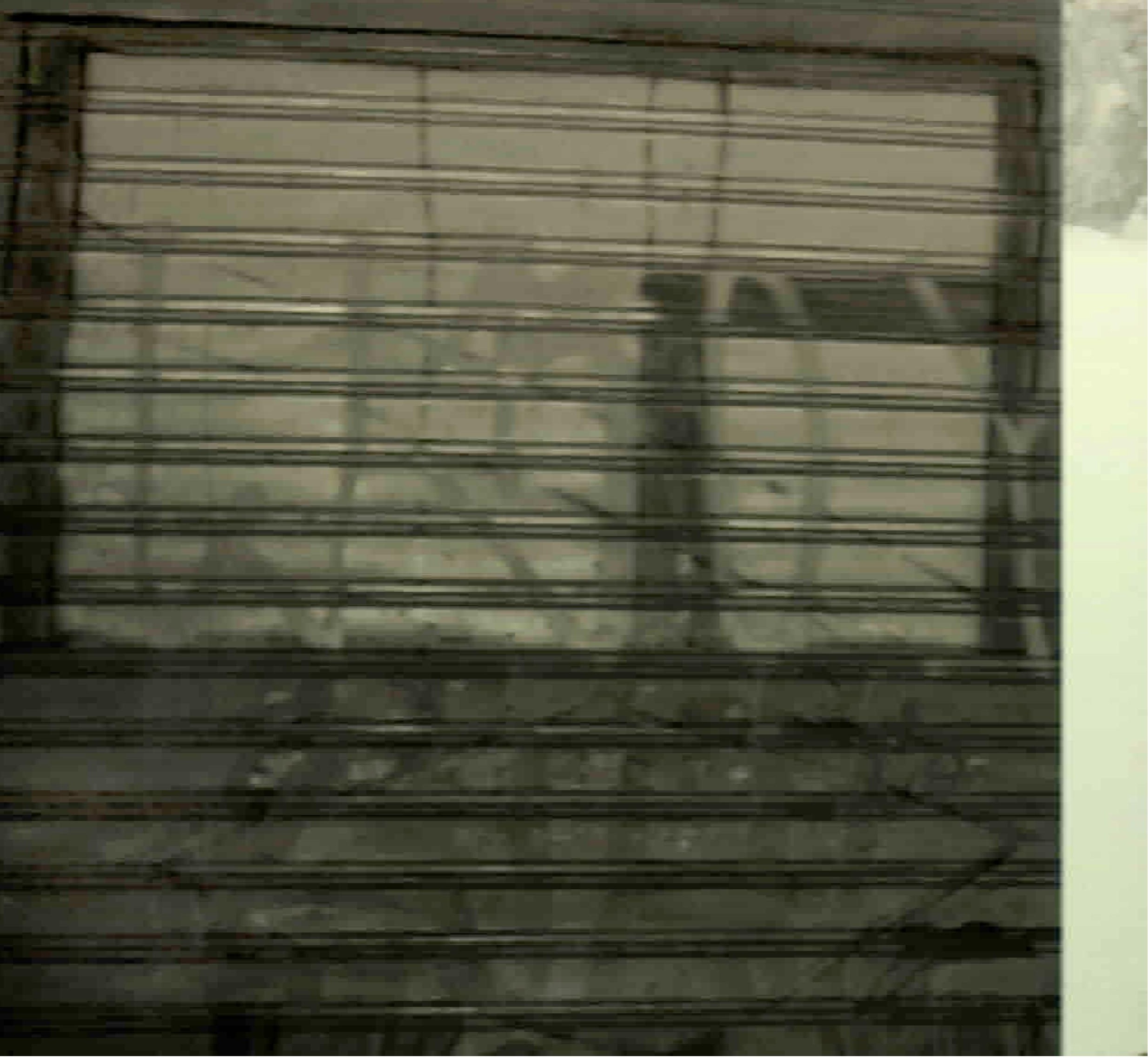




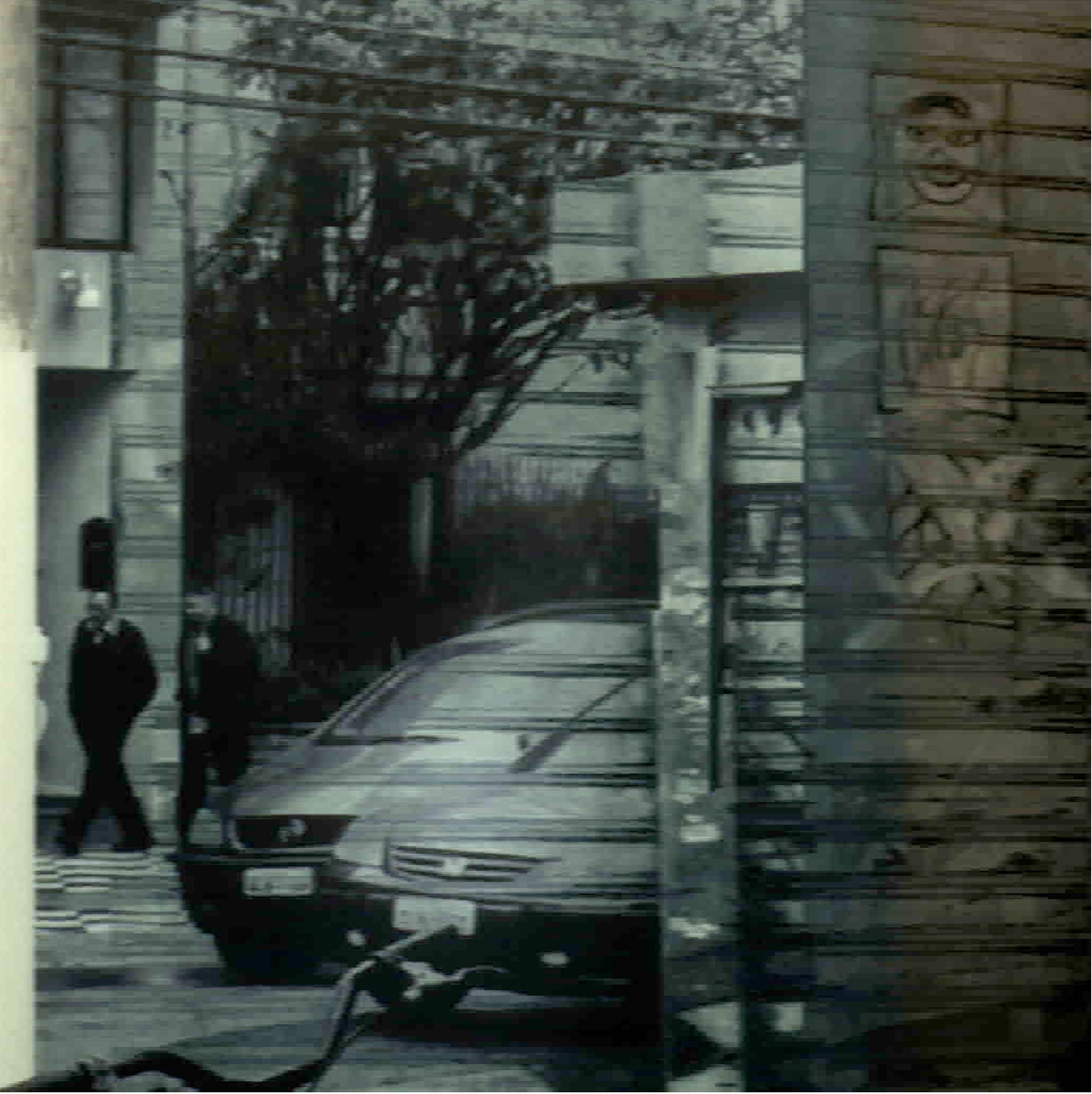




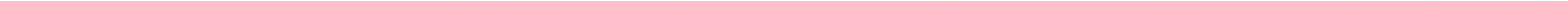




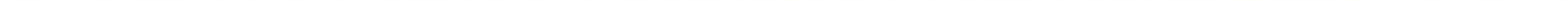




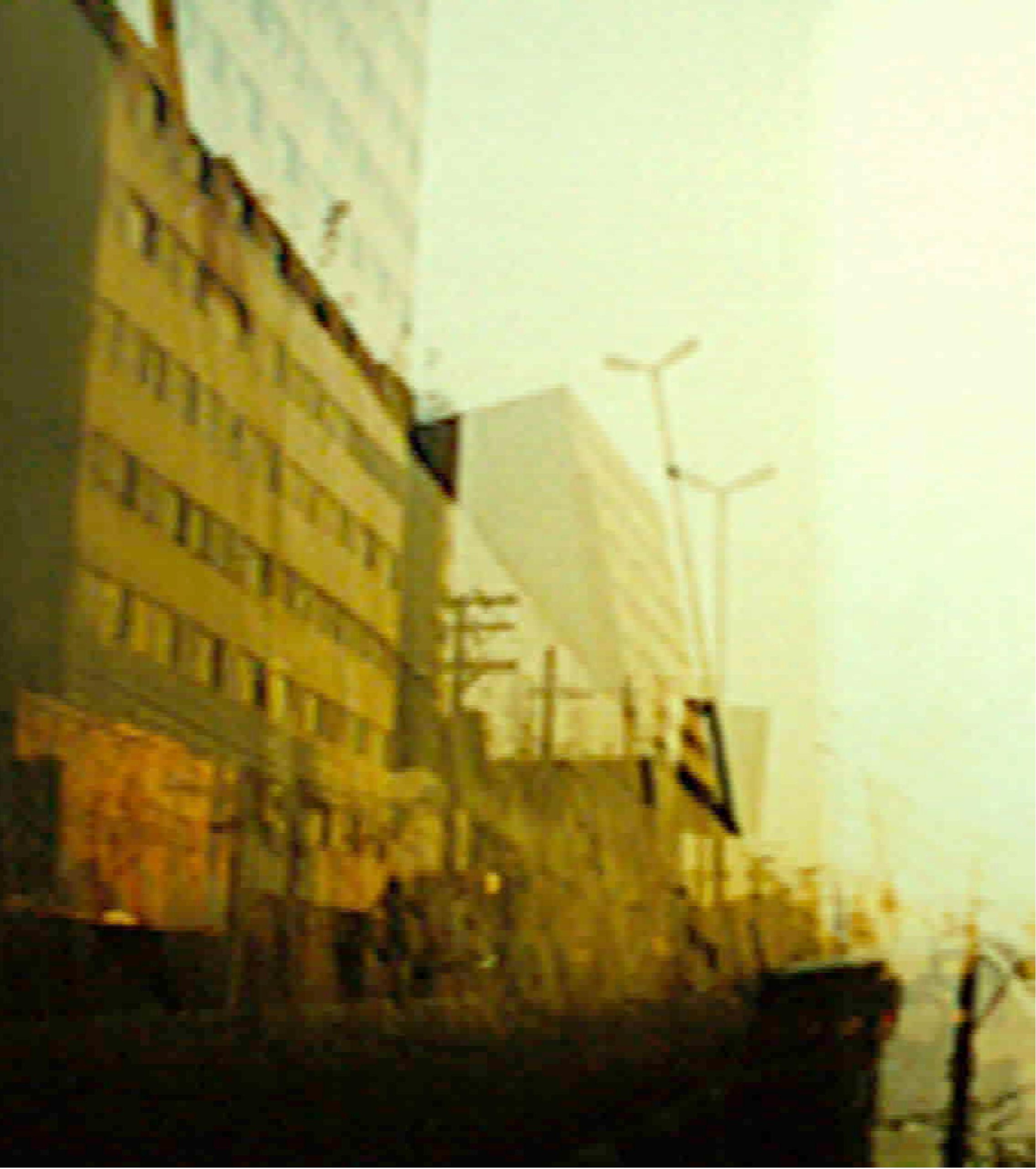




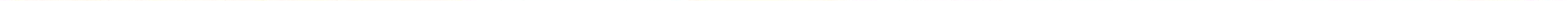




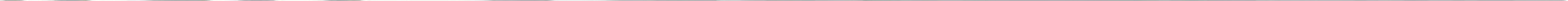




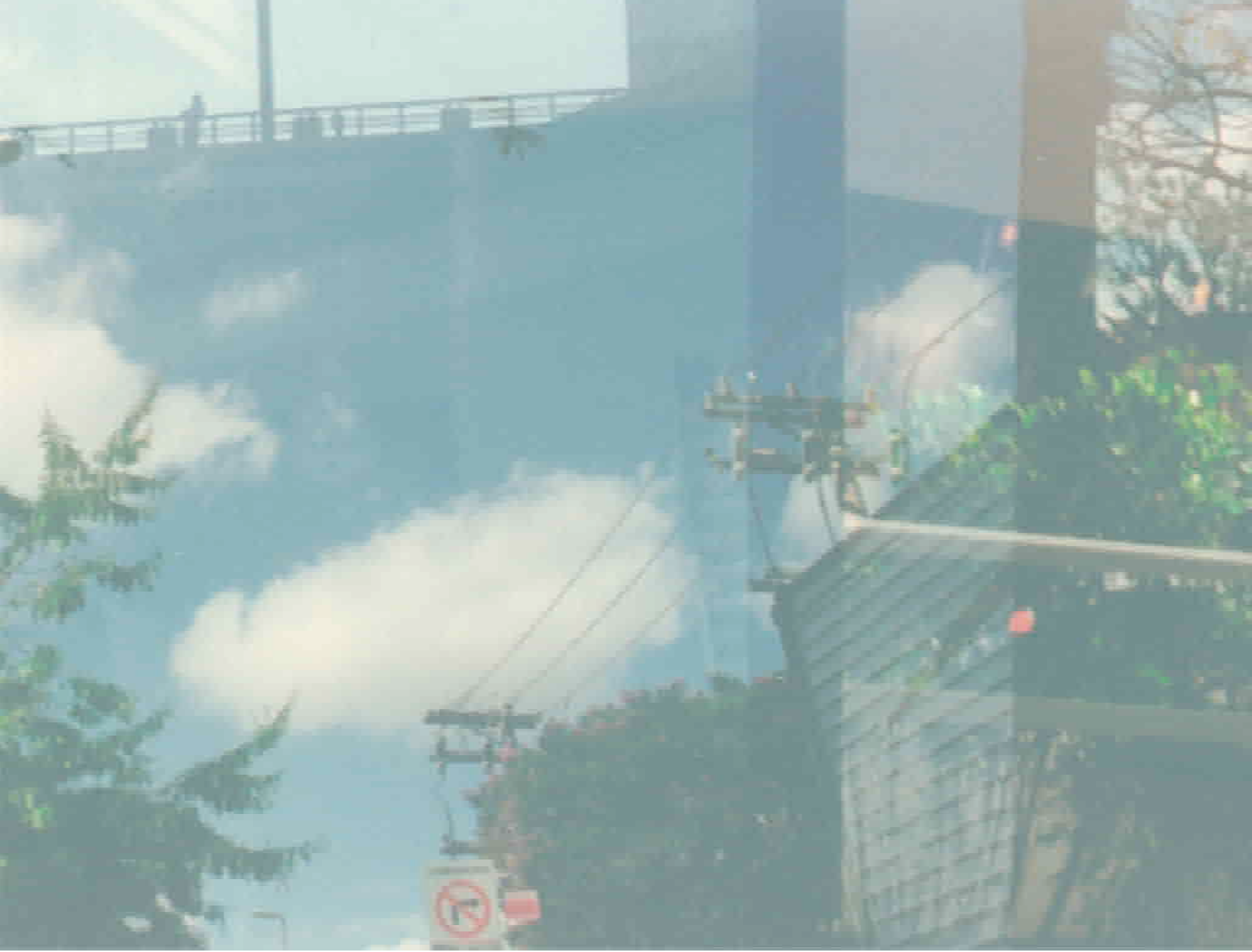




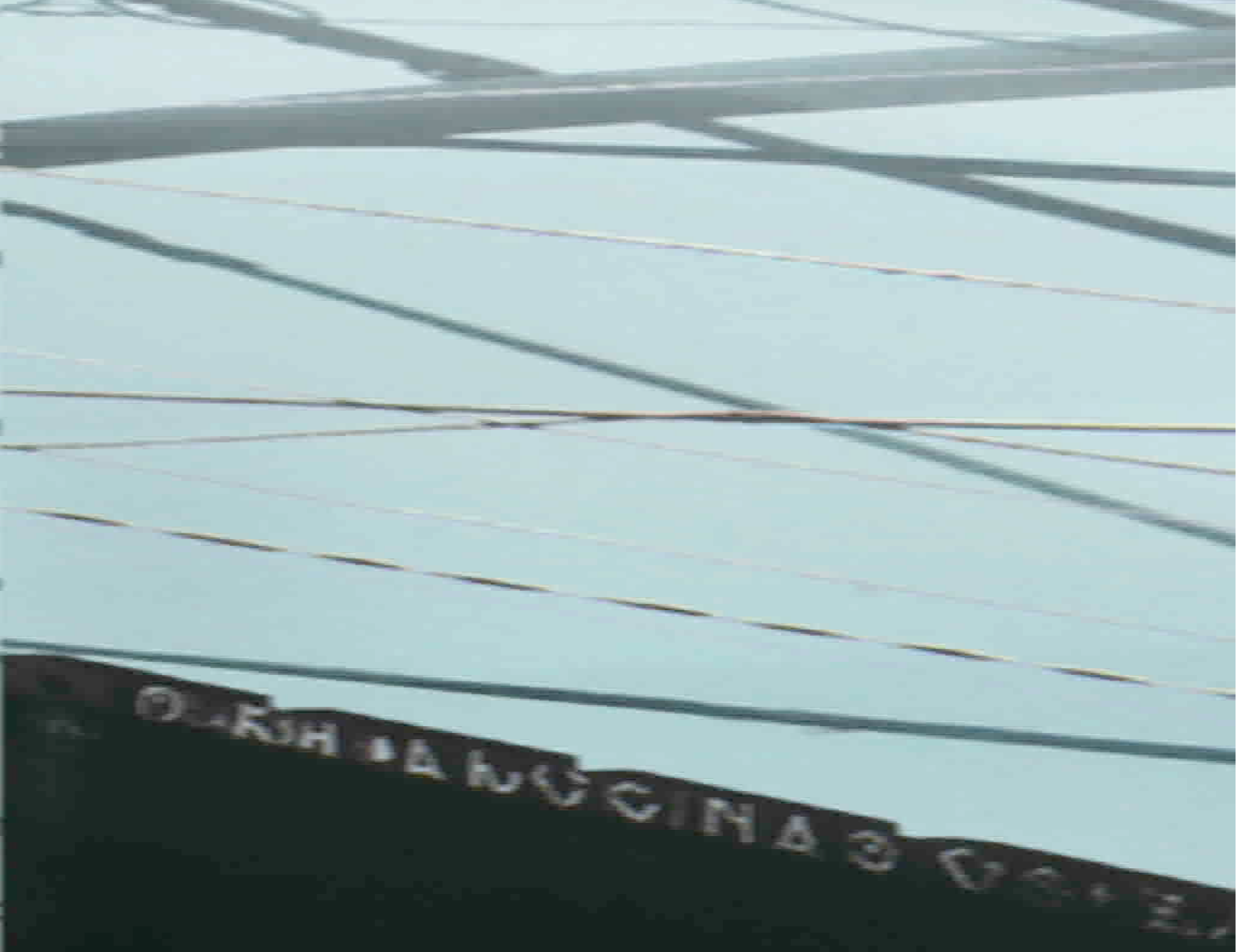

